\title{
Oxidative Stress in Neurodegenerative Diseases
}

\author{
Ewa Niedzielska $^{1} \cdot$ Irena Smaga $^{1} \cdot$ Maciej Gawlik $^{1} \cdot$ Andrzej Moniczewski $^{1}$ • \\ Piotr Stankowicz $^{1}$ - Joanna Pera ${ }^{2}$ - Malgorzata Filip ${ }^{1,3}$ (D)
}

Received: 5 March 2015 / Accepted: 1 July 2015 / Published online: 22 July 2015

(C) The Author(s) 2015. This article is published with open access at Springerlink.com

\begin{abstract}
The pathophysiologies of neurodegenerative diseases, including amyotrophic lateral sclerosis (ALS), Parkinson's disease (PD), and Alzheimer's disease (AD), are far from being fully explained. Oxidative stress (OS) has been proposed as one factor that plays a potential role in the pathogenesis of neurodegenerative disorders. Clinical and preclinical studies indicate that neurodegenerative diseases are characterized by higher levels of OS biomarkers and by lower levels of antioxidant defense biomarkers in the brain and peripheral tissues. In this article, we review the current knowledge regarding the involvement of OS in neurodegenerative diseases, based on clinical trials and animal studies. In addition, we analyze the effects of the drug-induced modulation of oxidative balance, and we explore pharmacotherapeutic strategies for OS reduction.
\end{abstract}

Keywords Alzheimer's disease $\cdot$ Amyotrophic lateral sclerosis · Antioxidant defense molecule $\cdot$ Non-enzymatic and enzymatic antioxidant - Oxidative stress biomarker .

Parkinson's disease $\cdot$ ESR — electron spin resonance ·

IST-immuno-spin trapping technique

Małgorzata Filip

mal.fil@if-pan.krakow.pl

1 Department of Toxicology, Chair of Toxicology, Faculty of Pharmacy, Jagiellonian University, Medical College, Medyczna 9, 30-688 Kraków, Poland

2 Department of Neurology, Faculty of Medicine, Jagiellonian University, Medical College, Botaniczna 3, 31-503 Krakow, Poland

3 Laboratory of Drug Addiction Pharmacology, Institute of Pharmacology, Polish Academy of Sciences, Smetna 12, 31-343 Kraków, Poland

$\begin{array}{ll}\text { Abbreviations } \\ \text { 3-NT } & \text { 3-Nitrotyrosine } \\ \text { 4-HDA } & \text { 4-Hydroxyalkenal } \\ \text { 5-OHC } & \text { 5-Hydroxycytosine } \\ \text { 5-OHU } & \text { 5-Hydroxyuracil } \\ \text { 6-OHDA } & \text { 6-Hydroxydopamine } \\ { }^{62} \text { Cu- } & \text { Copper-diacetyl-bis(N4- } \\ \text { ATSM } & \text { methylthiosemicarbazone } \\ \text { 8-OHA } & \text { 2,8-Hydroxyadenine } \\ \text { 8-OHdG } & \text { 8-Hydroxy-2'-deoxyguanosine } \\ \text { 8-OHG } & \text { 8-Hydroxyguanine } \\ \text { AD } & \text { Alzheimer's disease } \\ \text { AGE } & \text { Advanced glycation end product } \\ \text { ALE } & \text { Advanced lipid peroxidation end product } \\ \text { ALS } & \text { Amyotrophic lateral sclerosis } \\ \text { AOPP } & \text { Advanced oxidation protein products } \\ \text { APOE } & \text { Apolipoprotein E } \\ \text { APP } & \text { Amyloid precursor protein } \\ \text { ATP } & \text { Adenosine triphosphate } \\ \text { A } \beta & \text { Beta amyloid } \\ \text { CAT } & \text { Catalase } \\ \text { COMT } & \text { Catechol-O-methyltransferase } \\ \text { COX } & \text { Cyclooxygenase } \\ \text { CSF } & \text { Cerebrospinal fluid } \\ \text { CTL } & \text { Creatol (5-hydroxycreatinine) } \\ \text { CTX } & \text { Cortex } \\ \text { CYP 450 } & \text { Cytochrome P450 } \\ \text { DHE } & \text { Docosahexaenoic acid } \\ \text { eNOS } & \text { Endothelial nitric oxide synthetase } \\ \text { EPA } & \text { Eicosapentaenoic acid } \\ \text { ESR } & \text { Electron spin resonance } \\ \text { ETC } & \text { Electron transport chain } \\ \text { F2-isoPs } & \text { F2-isoprostanes } \\ \text { F4-NP } & \text { F4-neuroprostane } \\ \text { FALS } & \text { Familial amyotrophic lateral sclerosis } \\ & \end{array}$




\begin{tabular}{|c|c|}
\hline FDA & Food and Drug Administration \\
\hline GPx & Glutathione peroxidase \\
\hline GPx1 & Glutathione peroxidase-1 \\
\hline GR & Glutathione reductase \\
\hline GSH & Glutathione \\
\hline $\begin{array}{l}\text { GSH/ } \\
\text { GSSG }\end{array}$ & Reduced/oxidized glutathione ratio \\
\hline GSSG & Oxidized glutathione \\
\hline GSSG/ & Oxidized/reduced glutathione ratio \\
\hline GSH & \\
\hline GST & Glutathione $S$-transferase \\
\hline HD & Huntington disease \\
\hline HETE & Hydroxyeicosatetraenoic acid \\
\hline HIF-1a & Hypoxia-inducible factor-1a \\
\hline HIP & Hippocampus \\
\hline HNE & 4-Hydroxynonenal \\
\hline HODE & Hydroxyoctadecadienoic acid \\
\hline iNOS & Inducible nitric oxide synthetase \\
\hline i.c.v. & Intracerebroventricular \\
\hline i.p. & Intraperitoneal \\
\hline i.v. & Intravenous \\
\hline $\begin{array}{l}\text { Intra-SNc } \\
\text { inj. }\end{array}$ & Intra-substantia nigra injection \\
\hline $\begin{array}{l}\text { Intra-STR } \\
\text { inj. }\end{array}$ & Intrastriatal injection \\
\hline IsoF & Isofuran \\
\hline IST & Immuno-spin trapping technique \\
\hline LF & Lipofuscin \\
\hline LOX & Lipoxygenase \\
\hline LPO & Lipid hydroperoxide \\
\hline Lyso PC & Lysophosphatidylcholine \\
\hline MAO & Monoaminooxidase \\
\hline MAO-B & Monoamine oxidase B \\
\hline MDA & Malondialdehyde \\
\hline MPO & Myeloperoxidase \\
\hline MPTP & 1-Methyl-4-phenyl-1,2,3,6-tetrahydropyridine \\
\hline $\mathrm{NADH}$ & $\begin{array}{l}\text { Reduced form of nicotinamide adenine } \\
\text { dinucleotide }\end{array}$ \\
\hline MRI & Magnetic resonance imaging \\
\hline NADPH & $\begin{array}{l}\text { Reduced form of nicotinamide adenine dinu- } \\
\text { cleotide phosphate }\end{array}$ \\
\hline NF & Neurofuran \\
\hline nNOS & Inducible nitric oxide synthetase \\
\hline NOX & NADPH oxidase \\
\hline $\mathrm{ONOO}^{-}$ & Peroxynitrite \\
\hline NS & Nitrosative stress \\
\hline Opht A & Ophthalmic acid \\
\hline ox-LDL & Oxidized LDL \\
\hline OS & Oxidative stress \\
\hline p.o. & Per os \\
\hline PC & Protein carbonyl \\
\hline $\mathrm{PD}$ & Parkinson's disease \\
\hline PET & Positron emission tomography \\
\hline
\end{tabular}

\begin{tabular}{ll} 
Prx & Peroxiredoxin \\
Prx2 & Peroxiredoxin-2 \\
PSEN 1 & Gene encoding presenilin 1 \\
RIA & Radioimmunoassay \\
RNS & Reactive nitrogen species \\
ROS & Reactive oxygen species \\
s.c. & Subcutaneous \\
SAG & Superoxide anion generation \\
SALS & Sporadic amyotrophic lateral sclerosis \\
SN & Substantia nigra \\
SNpc & Substantia nigra pars compacta \\
SOD & Superoxide dismutase \\
SOD1 & Copper/zinc superoxide dismutase \\
STR & Striatum \\
TAC & Total antioxidant capacity \\
TBARS & Thiobarbituric acid reactive substances \\
TQ/TQH2 & Tocopherylquinone/tocopheryl hydroquinone \\
Trx & Thioredoxin \\
TSE & Aqueous extract of tomato seeds \\
TT & Total thiol \\
Tyr & Tyrosine \\
UQ/UQH2 & Ubiquinone/ubiquinol \\
XO & Xanthine oxidase \\
$\omega-3$ FA & Omega-3 fatty acid \\
\hline
\end{tabular}

\section{Introduction}

Identifying factors that contribute to neurodegenerative processes in the brain is one of the major goals of modern medicine. Currently, there are several hypotheses concerning the mechanisms that lead to the damage and death of brain cells in neurodegenerative diseases, such as excitotoxic effects by excitatory amino acids, disturbed cellular energy metabolism, and oxidative stress (OS), which is caused by free radicals or other reactive molecules.

The excessive production of reactive species and insufficient activity of antioxidant defense mechanisms have been implicated in the pathogenesis of many neurodegenerative diseases, including amyotrophic lateral sclerosis (ALS), Parkinson's disease (PD), Alzheimer's disease (AD), and Huntington disease (HD) [1].

\section{Reactive Species, Sources, and Cellular Pro-/Antioxidant Balance}

It is thought that the biological oxidants that cause oxidative damage comprise the products of endogenous and exogenous processes that involve oxygen and nitrogen. Reactive species that contain oxygen are produced during aerobic respiration, cellular metabolism, and defense against pathogens [2]. The chemical potential of the oxygen molecule relies on its 
electron structure (two unpaired electrons in its basic triplet state). It promotes one-electron reactions that form the basis for respiration (reduction of oxygen molecules in four singleelectron reactions), microsomal electron transport chains (ETC) (via cytochrome P-450 (CYP 450)), and oxidative burst activity in macrophages [3].

The high dynamics of the chemical processes that are achieved in elementary single-electron reactions are desirable and are the source of reactive molecules, which are either undesirable side products (respiration and metabolism) or in excess of the established requirements (defense process). These reactive molecules are known as reactive oxygen species (ROS) and reactive nitrogen species (RNS). Among them, the best known are singlet oxygen $\left({ }^{1} \mathrm{O}_{2}\right)$, superoxide anion radicals $\left(\mathrm{O}_{2}{ }^{-\bullet}\right)$, hydroxyl radicals $\left(\mathrm{HO}^{*}\right)$, hydrogen peroxide $\left(\mathrm{H}_{2} \mathrm{O}_{2}\right)$, nitric oxide $(\mathrm{NO})$, and peroxynitrite anions $\left(\mathrm{ONOO}^{-}\right)$ $[4,5]$.

At physiological concentrations, ROS/RNS play important regulatory and mediator functions, but an uncontrolled increase in ROS/RNS concentrations leads to a chain of radical reactions that increases the risk of damage to biological molecules in a living organism. This is caused by the high reactivity of ROS and RNS with lipids, proteins, carbohydrates, and nucleic acids. Hence, establishing an antioxidant barrier is required to limit the amount of ROS/RNS to a level that is not threatening to the integrity of biological systems. Excessive formation of ROS/RNS that exceeds the maximum capacity of the antioxidant barrier leads to a disturbance in the pro-/ antioxidant equilibrium and, finally, to the development of the state known as OS.

OS can be triggered by radicals produced by either exogenous processes (e.g., xenobiotics, cold, viral and bacterial infections, ionizing radiation, ultrasound or photo-oxidation, poor diet, alcohol consumption, and smoking) or endogenous processes, which are the basic biochemical reactions in the body mentioned earlier (Fig. 1).

ROS production as a side effect of aerobic respiration occurs on the inner membrane of the mitochondrion [6] (Fig. 2). The respiratory chain (mitochondrial ETC) consists of a series of membrane-bound complexes, such as complex I (reduced form of nicotinamide adenine dinucleotide (NADH)/ubiquinone reductase), complex II (succinate ubiquinone reductase), complex III (ubiquinol cytochrome c reductase), complex IV (cytochrome c oxidase), and complex V (adenosine triphosphate (ATP) synthase) [7]. The final acceptor of electrons and protons, an oxygen molecule, undergoes four-electron reduction, which can lead to the production of water molecules. During ETC, single electrons leak to reduce molecular oxygen and to form $\mathrm{O}_{2}{ }^{-}$and, later, $\mathrm{H}_{2} \mathrm{O}_{2}$ and $\mathrm{HO}^{-}$[8] (Fig. 1).

Because of its high consumption of oxygen and its high lipid content, the brain is particularly vulnerable to damage caused by ROS and RNS. The extent of the damage varies, depending on, among other factors, the source and type of the reactive species. More active molecules, such as $\mathrm{HO}^{\circ}$ and $\mathrm{ONOO}^{-}$, interfere with other molecules at the site of their production, while less active ones, such as ${ }^{1} \mathrm{O}_{2}$ and $\mathrm{O}_{2}{ }^{-}$, can diffuse over longer distances and produce effects in more specific locations [9]. They can also react with each other and form more active forms, as in the case of the reaction of $\mathrm{O}_{2}{ }^{-}$ with $\mathrm{NO}$, which creates $\mathrm{ONOO}^{-}[10]$.

In mitochondria, $\mathrm{NO}$ is produced from L-arginine and Lcitrulline in a reaction that is catalyzed by nitric oxide synthase (NOS), which has three isoforms with different tissue localizations. Cellular $\mathrm{Ca}^{2+}$-dependent neuronal NOS (nNOS) is expressed in astrocytes, microglia, and macrophages, and endothelial NOS (eNOS) is expressed in the vascular endothelium and $\mathrm{Ca}^{2+}$-independent inducible NOS (iNOS). NO is involved in many important processes within the central nervous system, such as the regulation of cerebral blood flow and memory. In addition, it plays a significant role in the regulation of the immune system, including the modulation of cytokine production. The released NO acts on neighboring cells, leading to somatic mutations and affecting cell cycle regulatory proteins, apoptosis, and DNA repair [11].

RNS are important for the generation of OS. $\mathrm{ONOO}^{-}$is rapidly decomposed into $\mathrm{HO}^{\circ}$, nitrogen dioxide radical $\left(\mathrm{NO}_{2}{ }^{\circ}\right)$, and nitryl cation $\left(\mathrm{NO}_{2}{ }^{+}\right)$. All of these can damage nerve cells [12].

These highly reactive compounds induce changes in the structure and function of cell membranes, proteins, lipoproteins, enzymes, hormones, and genetic material. In particular, membranes are a primary target for ROS. Conversion products of lipid peroxidation lead to the decomposition of polyunsaturated fatty acids and the formation of the final products, i.e., the reactive aldehydes, such as malondialdehyde (MDA) and 4-hydroxynonenal (HNE). These compounds react with DNA or protein molecules and modify their structure and functions $[13,14]$.

There are several mechanisms designed to protect the organism from the harmful effects of ROS and RNS. The ultimate amount of ROS/RNS is under strict control in the body as a result of enzymatic and non-enzymatic defense mechanisms. The production of ROS- and RNS-induced damage (the final effect of OS) in tissue can be confirmed by the presence of tissue-specific and non-specific biomarkers [15-20]. Several markers of OS and antioxidant activity are presented in Fig. 2. Recent technical advances used to detect and identify ROS/RNS biomarkers and free radical metabolism are electron spin resonance (ESR), the immuno-spin trapping technique (IST), and radioimmunoassay (RIA) [21, 22].

The cellular antioxidant system, designed to prevent damage to tissue, is composed of antioxidant enzymes and other non-enzymatic compounds that have the ability to reduce different chemical structures [21]. These compounds are responsible for maintaining the balance between pro- and antioxidant 
Fig. 1 Generation of reactive species (based on [280-283])

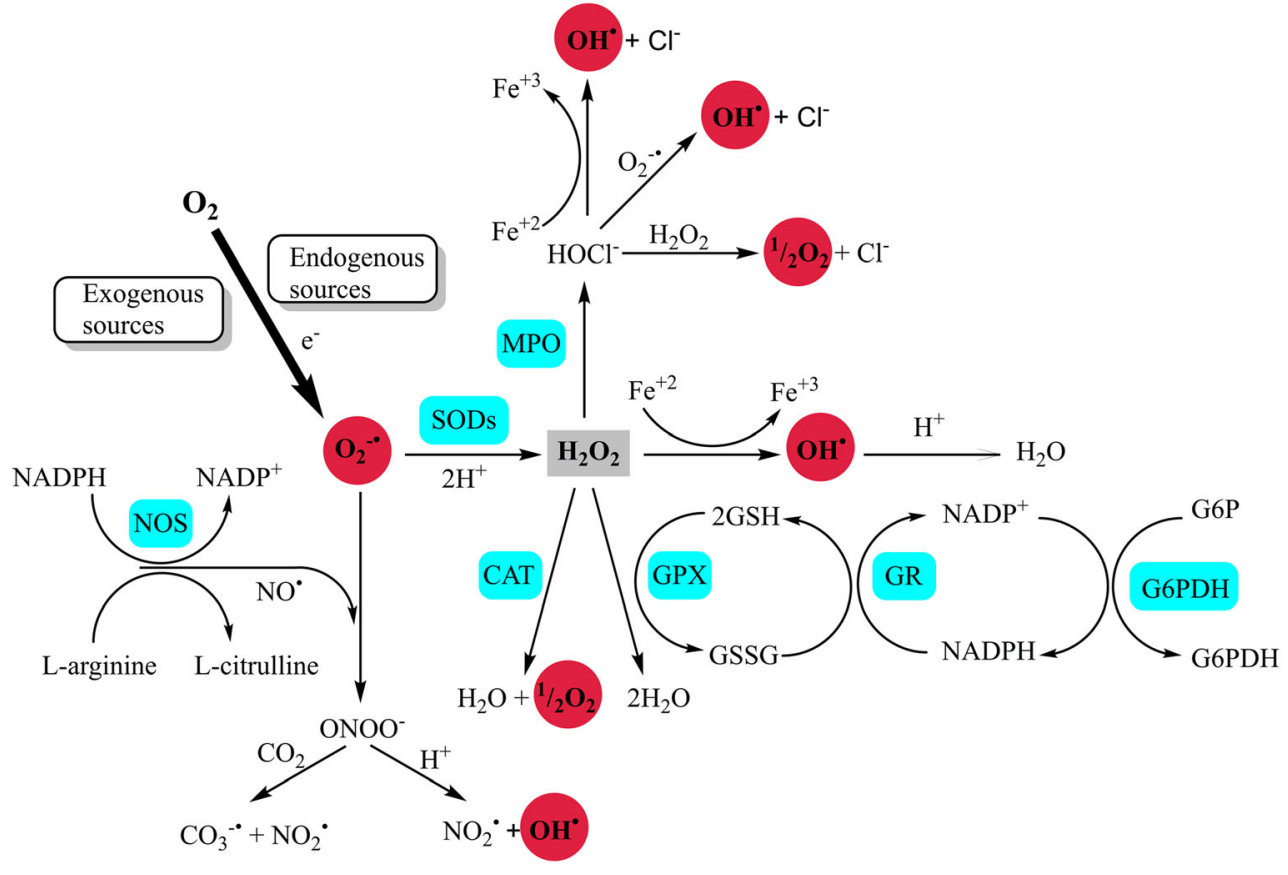

agents and alleviating OS (see Table 1). The essential components of the enzymatic antioxidant defense are superoxide dismutase (SOD), catalase (CAT), glutathione peroxidase (GPx), and glutathione reductase (GR), while the nonenzymatic antioxidants include glutathione (GSH), thioredoxin (Trx), vitamins A, E, and C, flavonoids, trace elements, and proteins, e.g., albumin, ceruloplasmin, and metallothionein.

A large body of evidence confirms a relationship between OS and the development of neurodegenerative diseases. The increased neuronal ROS production and accumulation of oxidative damage that occurs with age correlate well with the extent of neurodegeneration. In the following sections of this article, we present the current knowledge on the relationships between the intensity of OS and the initiation and progression of the major neurodegenerative diseases AD, PD, and ALS. The assessment of these relationships is based on biomarkers of OS and indicators of the pro-/antioxidant balance in nervous tissue that are correlated with the typical characteristics of neurodegenerative processes.

\section{Amyotrophic lateral sclerosis (ICD-10 G12.21)}

ALS (also known also as Charcot's or Lou Gehrig's disease) is a severe neurodegenerative disease that is characterized by progressive upper motor neuron loss in the cerebral cortex and lower motor neuron loss in the brainstem and spinal cord $[23,24]$. This results in spasticity, muscle wasting, and weakness, leading finally to paralysis and difficulties with speech, swallowing, and breathing. ALS may have either a limb onset (80\% cases) or a bulbar onset (20\% cases) $[24,25]$. There is currently no cure for ALS and only riluzole, which acts on glutamate signaling, has been registered for the treatment of the disease. Riluzole was shown to slow disease progression and to improve limb function; however, the survival of patients was prolonged by only $2-3$ months and death due to respiratory failure occurred in most cases within 3-5 years of the diagnosis [26].

The main pathological hallmark of ALS is the formation of cytoplasmic aggregates in degenerating motor neurons and surrounding oligodendrocytes, but those inclusions are also present in the frontal and temporal cortices, hippocampus, and cerebellum [27].

Only 5-10\% of ALS cases are inherited (familial ALS (FALS)); the remaining cases have no clear genetic background (sporadic ALS (SALS)) [24], and their pathogenesis is still poorly understood. Studies concerning the mechanisms of ALS development indicate that many factors, including excitotoxicity, mitochondrial dysfunction, endoplasmic reticulum stress, neuroinflammation, and OS, can be involved in this process. The two forms of the disease are clinically indistinguishable because the symptoms and pathological changes in SALS and FALS are similar. FALS is caused by mutations in some genes, such as those coding for SOD1, FUS RNA binding protein, TAR DNA binding protein, vesicleassociated membrane protein $\mathrm{B}$, valosin-containing protein, optineurin, alsin, senataxin, spatascin, angiogenin, or ubiquilin-2 [24, 26]. Some of these gene mutations have also been found in SALS patients [28, 29].

The most common known genetic mutation for ALS is the recently described expanded GGGGCC hexanucleotide repeat in the non-coding region of the C9Orf72 gene, on 


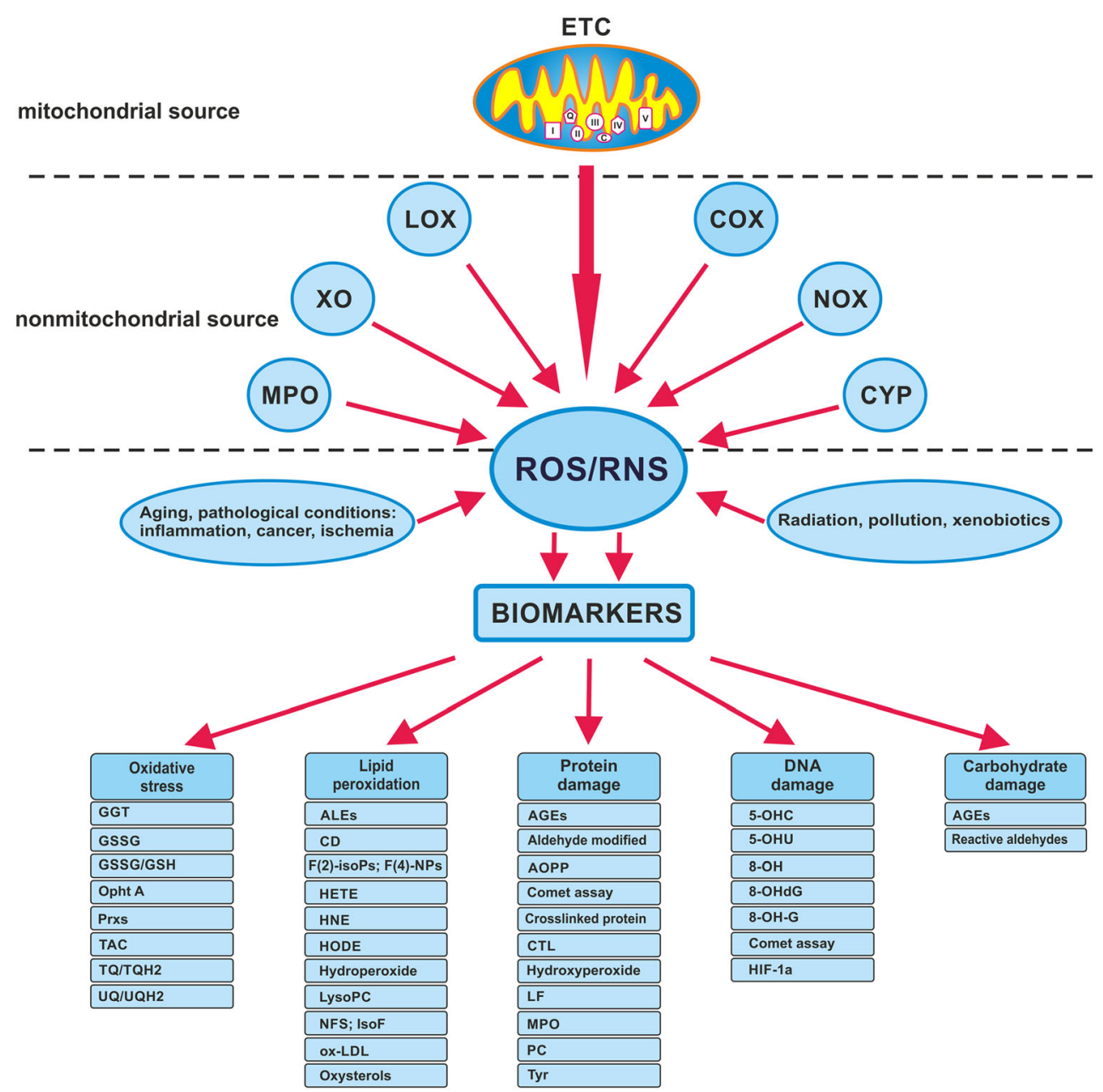

Fig. 2 Source of radical and OS biomarkers. 8-OHA 2,8hydroxyadenine, $H N E$ 4-hydroxynonenal, 5-OHC 5-hydroxycytosine, 5-OHU 5-hydroxyuracil, 8-OHdG 8-hydroxy-2'-deoxyguanosine, 8$O H$-Gua 8-hydroxyguanine, AGEs advanced glycation end products, $A L E S$ advanced lipid peroxidation end products, $A O P P$ advanced oxidation products, $C T L$ creatol, $C O X$ cyclooxygenases, $C Y P$ cytochrome P450, ETC electron transport chain, F2-isoPs F2isoprostanes, F4-NPS F 4-neuroprostanes, HETE hydroxyeicosatetraenoic acids, $H O D E$ hydroxyoctadecadienoic acid,

chromosome 9p21 [30]. Another common mutation is localized in SOD1. SOD1 in its native state metabolizes $\mathrm{O}_{2}^{-\bullet}$ to molecular misfolding [31]. Pathogenic mutations of SOD1 enzyme can be present in different regions of the enzyme, e.g., G93A (glycine 93 changed to alanine), H46R (histidine at codon 46 changed to arginine), or A4V (alanine at codon 4 changed to valine). Mutated SOD1 can form cytotoxic protein aggregates alone or with other proteins what possibly leads to loss of the enzymatic function or to acquiring the toxic properties $[32,33]$. As SOD1 plays a crucial role in $\mathrm{O}_{2}{ }^{-}$clearance, its functional loss can lead to increased levels of OS. Then, the remaining wild-type SOD1 may become itself a target of oxidative modification after which it dissociates from dimers to monomers and further forms aggregates with toxic properties of mutant forms of SOD1. That was shown in in vitro studies
$H I F-1 a$ hypoxia-inducible factor-1a, $I s o F$ isofuran, $L F$ lipofuscin, $L O X$ lipoxygenases, Lyso $P C$ lysophosphatidylcholines, $M P O$ myeloperoxidase, NOX NADPH oxidases, NFS neurofuran, Opht $A$ ophthalmic acid, GSSG oxidized glutathione, $o x-L D L$ oxidized LDL, GSSG/GSH oxidized/reduced glutathione, Prxs peroxiredoxins, $P C$ protein carbonyl, TBARS thiobarbituric acid reactive substances, $T Q$ $T Q H 2$ tocopherylquinone/tocopheryl hydroquinone, $T A C$ total antioxidant capacity, Tyr tyrosines, $U Q / U Q H 2$ ubiquinone/ubiquinol, $X O$ xanthine oxidase

$[34,35]$. Accumulation of abnormal SOD1 was also confirmed in the spinal cord [34] in animal studies [36, 37] as well as in ALS patients [38].

\section{Clinical Studies}

\section{OS Biomarkers}

Post-mortem studies on tissue samples from SALS and FALS patients support the hypothesis of oxidative damage of proteins, lipids, and DNA. For instance, HNE and 3nitrotyrosine (3-NT) levels were increased in CSF in SALS patients $[39,40]$, while a rise in 8-hydroxy-2'deoxyguanosine $(8-\mathrm{OHdG})$ has been described in both 
Table 1 Enzymatic and non-enzymatic antioxidants against OS

\begin{tabular}{|c|c|}
\hline Agents & Mechanism \\
\hline \multicolumn{2}{|l|}{ Enzymatic } \\
\hline $\begin{array}{l}\text { Superoxide dismutases (SOD) } \\
\text { CuZn-SOD, located in the cytoplasm } \\
\text { Mn-SOD, located in the mitochondria } \\
\text { EC-SOD extracellular }\end{array}$ & Scavenges superoxide anion to form $\mathrm{H}_{2} \mathrm{O}_{2}$ \\
\hline Catalases (CATs) & Peroxisomes remove the hydrogen peroxide \\
\hline Peroxiredoxins (Prxs) & Reduce free hydrogen peroxide to water \\
\hline Glutathione peroxidases (GPx) & Catalyzes the reduction of $\mathrm{H}_{2} \mathrm{O}_{2}$ and alkyl hydroperoxides to $\mathrm{H}_{2} \mathrm{O}$ \\
\hline Glutathione reductases (GRs) & Catalyzes the reduction of oxidized glutathione (GSSG) to reduced glutathione (GSH) \\
\hline Glutathione $S$-transferases (GSTs) & $\begin{array}{l}\text { Catalyze the conjugation of xenobiotics and endogenous or exogenous electrophilic } \\
\text { compounds to reduced glutathione }\end{array}$ \\
\hline Thioredoxin reductases (TrxRs) & Repair oxidative damages of proteins \\
\hline Heme oxygenase-1 (HO-1) & Creation of products with antioxidant properties \\
\hline \multicolumn{2}{|l|}{ Metalloproteins } \\
\hline Metallothionein (MT) & Physiological metal chelation ( $\mathrm{Zn}, \mathrm{Cu}, \mathrm{Se})$ and xenobiotic metals $(\mathrm{Cd}, \mathrm{Hg}, \mathrm{Ag}, \mathrm{As})$ \\
\hline Albumin & Chelation of metal ions $(\mathrm{Fe}, \mathrm{Cu})$ \\
\hline Ceruloplasmin (CP) & Chelation of metal ions $(\mathrm{Cu})$ \\
\hline Ferritin & Chelation of metal ions $(\mathrm{Fe})$ \\
\hline Transferrin & Chelation of metal ions $(\mathrm{Fe})$ \\
\hline \multicolumn{2}{|l|}{ Non-enzymatic } \\
\hline Vitamin C (ascorbic acid) & ROS scavenger \\
\hline Vitamin E ( $\alpha$-tocopherol) & ROS scavenger \\
\hline Vitamin A (retinol) & ROS scavenger \\
\hline Carotenoids & ROS scavenger \\
\hline Melatonin & ROS scavenger \\
\hline $\begin{array}{l}\text { Reduced nicotinamide adenine dinucleotide phosphate } \\
\text { (NADPH) }\end{array}$ & Coenzyme used in anabolic reactions \\
\hline Adenosine (ADO) & Endogenous activator of the cellular antioxidant defense system \\
\hline Uric acid & ROS scavenger \\
\hline Ubiquinol (the reduced form of coenzyme Q-10) & ROS scavenger \\
\hline $\begin{array}{l}\text { Polyphenols } \\
\text { Phenolic acids } \\
\text { Flavonoids } \\
\text { Stilbenes }\end{array}$ & ROS scavenger, metal chelation, induction of antioxidant enzymes \\
\hline GSH reduced glutathione & ROS scavenger \\
\hline Amino acids (cysteine, homocysteine, methionine, taurine) & ROS scavenger \\
\hline$\alpha$-Lipoic acid & ROS scavenger \\
\hline Lycopene & ROS scavenger \\
\hline Carotenoids & ROS scavenger \\
\hline S-adenosyl-L -methionine & ROS scavenger \\
\hline Selenium & ROS scavenger \\
\hline
\end{tabular}

Data from [274-279]

SALS and FALS patients [41, 42]. However, no correlation between these markers and the severity or duration of the disease has been found [43].

Raised levels of thiobarbituric acid reactive substances (TBARS) and advanced oxidation protein products (AOPP) and decreased ferric-reducing ability of plasma (FRAP) were detected in the plasma or erythrocytes of SALS patients
[44-46], but plasma protein carbonyl (PC) levels surprisingly did not differ between SALS patients and control subjects [16]. More conclusive results came from a study where urine from SALS patients contained a higher level of isoprostanoids (IsoPs) and 8-OHdG compared to a control group [16, 47], suggesting that IsoPs and $8-\mathrm{OHdG}$ could be considered markers of OS in ALS. These studies included only 50 
participants with SALS compared to 46 control subjects. Thus, these results should be confirmed in larger cohorts.

The presence of OS biomarkers in regions of the CNS that are critical for ALS suggests that they are implicated in motor neuron degeneration. This fact is supported by very recent positron emission tomography (PET) imaging data in humans, which confirmed that OS were enhanced in the motor cortex in ALS patients compared with controls. Moreover, the observed OS increase in the mild stage of the disease led to the conclusion that OS may be an important factor associated with the development of neurodegeneration in ALS patients [48].

\section{Antioxidant Defense Biomarkers}

Most studies concerning antioxidant defense biomarkers in ALS patients have shown changes in peripheral tissues or in CSF but rarely in the brain. For example, GSH levels were reduced in erythrocytes in ALS patients [45]. In contrast, an earlier study demonstrated a lower GSSG/GSH ratio with a concomitant rise in NO in the CSF of SALS patients [49]. According to the latter study, the lower GSSG/GSH level was caused by the decreased production of $\mathrm{O}_{2}^{-{ }^{-}}$-oxidizing GSH because of the shift of oxidation to NO production or oxidation [49]. Very recent in vivo imaging studies have shown decreased GSH levels in the motor cortex of ALS patients by using the J-editing technique or ${ }^{62}$ copperdiacetyl-bis(N4-methylthiosemicarbazone $\left({ }^{62} \mathrm{CU}\right.$-ATSM)) PET technique [25, 48].

The activity of SOD decreased in red blood cells and the CSF of FALS- and SALS-diagnosed patients [42, 50-52]. Interestingly, the reduction in the SOD1 protein concentration in erythrocytes of FALS patients correlated with $S O D 1$ gene mutations [42]. However, SALS patients displayed enhanced activity of SOD1 in CSF [53], indicating that this different outcome may depend on either the ALS type, the disease duration, or the sampling time [54].

Apart from SOD, the activity of CAT, another antioxidant defense enzyme, was also found to be diminished in red blood cells in FALS [51] and SALS [51, 52] patients. Another study revealed that CAT activity decreased in erythrocytes with disease progression, which may suggest a link between this parameter and ALS duration [45].

Results regarding GPx or GR activity in ALS patients are controversial. GPx type 3 (also known as plasma GPx) and GR levels were lower in the serum or in red blood cells, respectively, in ALS patients [45, 55]. In contrast, another study showed enhanced GPx in the serum and CSF of ALS patients [56], while GR activity was elevated in the erythrocytes in both SALS and FALS patients [51, 52]. One study reported no change in GR activity in red blood cells in SALS patients [57].

In ALS patients, the plasma and/or CSF levels of other antioxidants (i.e., vitamin $\mathrm{E}, \beta$-carotene, vitamin $\mathrm{C}$, uric acid, and thiol group-containing molecules, such as ubiquinol-10) were either elevated [53] or not changed [44, 58, 59].

These divergent results could be explained by the heterogeneity of ALS [60]. In fact, ALS-diagnosed patients vary in their rate of disease progression and may differ in the number of years of survival. The median survival from onset to death in ALS varies from 20 to 48 months; however, many studies have reported a survival time of longer than 10 years in $10-20 \%$ of patients [60]. Moreover, a study from Cova et al. [57] showed that the activity of GPx, GR, and CuZn SOD in erythrocytes was decreased in patients who had a faster disease progression rate and that SOD1 activity significantly decreased along the disease course in subjects with a more impaired functional status. All of these results support the hypothesis that ALS has many variants or mimic syndromes that differ in their pathogenic mechanisms and in their profile of enzymatic and non-enzymatic antioxidant responses [57].

\section{Pharmacological Strategies to Reduce OS}

Several pharmacotherapeutic agents with antioxidant properties have been attempted to slow ALS progression; however, most of them failed to do so (Table 2). Vitamin E, when combined with riluzole, diminished TBARS levels, enhanced GPx activity in the plasma, and prolonged the milder stages of the ALS Health State scale, but it did not affect survival and motor function [61].

Another study investigated a very high dose of vitamin E as an add-on therapy to riluzole for ALS treatment; however, this treatment with vitamin $\mathrm{E}$, at a dose of $5,000 \mathrm{mg} /$ day for 18 months, failed to slow disease progression [62]. On the other hand, another study showed that intake of a combination of polyunsaturated fatty acids and vitamin $\mathrm{E}$ reduced the risk of developing ALS [63].

Edavarone (MCI-186) is another free radical scavenger that is already approved to treat cerebral infarction and to investigate ALS. It eliminates lipid peroxide and hydroxyl radicals by transferring an electron to the radical and thereby exerting a protective effect on neurons. In ALS patients, edavarone was shown to diminish nitrosative stress (NS) in CSF [64] and is now being tested in a phase III clinical trial in Japan for ALS treatment [65]. Coenzyme Q10 was administered for 9 months in a dose of 2,700 mg/day to ALS patients in a multicenter trial that unfortunately showed a lack of compound efficacy for ALS treatment [66]. This study also determined 8-OHdG levels in the plasma; however, according to the authors, the results for this measure will only be available later [66].

Other antioxidant medications, i.e., acetylcysteine, creatine, or selegiline, had no significant effect on survival or the rate of clinical progression of ALS [67-69]. In these studies, the influence on antioxidant defense biomarkers and oxidant 
Table 2 Clinical trials in ALS patients with agents/drugs showing antioxidant properties

\begin{tabular}{|c|c|c|c|}
\hline Antioxidant & $\begin{array}{l}\text { Time point of antioxidant status determination from } \\
\text { the beginning of therapy }\end{array}$ & $\begin{array}{l}\text { Oxidative damage biomarker } \\
\text { change }\end{array}$ & Reference \\
\hline $\begin{array}{l}\text { Vitamin E (500 mg twice a day) with riluzole } \\
\quad(100 \mathrm{mg} / \text { day })\end{array}$ & 3 months & $\begin{array}{l}\uparrow \text { GPx in plasma, } \downarrow \text { TBARS } \\
\text { in plasma }\end{array}$ & {$[61]$} \\
\hline Selegiline hydrochloride ( $5 \mathrm{mg}$ twice a day p.o.) & 6 months & nd & {$[69]$} \\
\hline Acetylcysteine (50 mg/kg/day s.c.) & 12 months & nd & {$[68]$} \\
\hline Creatine ( $5 \mathrm{~g}$ twice a day p.o.) & 16 months & nd & {$[67]$} \\
\hline Coenzyme Q10 (1,800 and 2,700 mg/day p.o.) & 9 months & nd & {$[66]$} \\
\hline Edaravone (60 mg/day i.v.) & 2 weeks administration every 2 weeks, 6 replications & $\downarrow 3-\mathrm{NT}$ in $\mathrm{CSF}$ & {$[64]$} \\
\hline Melatonin $(300 \mathrm{mg} /$ day $)$ per rectum & 4 months & $\downarrow \mathrm{PC}$ in serum & {$[70]$} \\
\hline
\end{tabular}

$\downarrow$ decrease, $\uparrow$ increase, $n d$ not determined, 3-NT 3-nitrotyrosine, 8-OHG 8-hydroxyguanosine, CSF cerebrospinal fluid, GPx glutathione peroxidase, i.v. intravenously, p.o. per os, $P C$ protein carbonyl, s.c. subcutaneous, TBARS thiobarbituric acid reactive substances

damage was not evaluated. In another study, melatonin was used as a potential neuroprotective compound and, when normalized to control values, was found to elevate the level of PC in the serum of 31 SALS patients [70].

The novel antioxidant AEOL 10150, which is a small molecule that catalytically consumes ROS and RNS, is considered to be the most promising compound under evaluation in a clinical trial [71]. In a small, open-label study in ALS patients, AEOL 10150 was shown to be a safe and well-tolerated drug [71]. However, neither efficacy nor measurement of oxidative biomarkers in ALS patients who were on AEOL 10150 has been published.

The antioxidant medications used in ALS clinical trials have so far been unable to slow the progression of the disease. Moreover, a limited number of clinical studies have investigated oxidative damage or changes in the antioxidant defense status after antioxidant therapy.

\section{Anti-ALS Drugs that Modulate the Oxidative Balance}

No data.

\section{Animal Studies}

\section{OS Biomarkers}

The most popular animal models of ALS are based on SOD1 mutant transgenic mice (for example: SOD1 G93A, SOD1 H46R, SOD1 H46R/H48Q, SOD1 A4V, etc. (for more details, see [72])). Other ALS models include Wobbler mice and rodent models with genetic mutations in TAR DNA binding protein of $43 \mathrm{kDa}$ (TDP-43), VAMP-associated protein $\mathrm{B}$, dynactin or FUS/TLS, or C9Orf72 [73].

Changes in oxidative biomarkers have been detected in ALS models in rodents (Table 3). For example, free radical levels were elevated in the spinal cord of SOD1 G93A mice post-mortem $[74,75]$, and trapped radical adducts were also recently detected in the spinal cord of these mice in vivo [76]. In line with this latter observation, increased levels of PC in the spinal cord and in the motor cortex [77, 78], MDA and 4HDA in the brain and CSF [79], and HNE, HNE-adducts, and $8-\mathrm{OHdG}$ in the spinal cord $[80,81]$ have been observed in several ALS animal models (see Table 3).

It has been established that enhanced nitration processes are also present in animal models of ALS. For example, 3NT was found in the spinal cords of aged SOD1 G93A mice together with the presence of overnitrated proteins (actin or ATPase) in the spinal cord [82], in the motor and sensory cortices [78], and in the peripheral blood mononuclear cells [83] in transgenic mouse models of ALS and that these were observed even before the onset of the disease.

OS and NS are widely present in ALS, and in vitro studies suggest that this mechanism can facilitate the formation of protein aggregates [84]. In support of this conclusion, recent studies have revealed that a selective nNOS inhibitor increased survival in SOD1 transgenic mice [85].

\section{Antioxidant Defense Biomarkers}

In general, transgenic mouse models overexpressing mutant human SOD1 showed increased activity by the enzyme [32]. However, in the end stage of the disease, SOD1 activity in SOD1 G93A mice remained at the same level as wild-type SOD in non-transgenic mice [86]. What is interesting is that SOD1 knockout mice did not show an ALS-like phenotype [32].

Other antioxidant biomarkers, including GSH, GPx, and GR, are also changed during the course of ALS. The levels of GSH differed in mice carrying different SOD1 mutations. For example, in SOD1 G93A mutant mice, the GSH level decreased and the level of GSSG rose in the lumbar spinal cord [87], while in the same tissue in SOD1 mice with the 
Table 3 OS biomarkers in ALS animal model

\begin{tabular}{|c|c|c|}
\hline Animal model & OS biomarkers & Reference \\
\hline Mice SOD1 G93A-2Gur & $\uparrow \mathrm{PC}$ in spinal cord & {$[77]$} \\
\hline \multirow[t]{2}{*}{ Mice SOD1 G93A } & $\uparrow \mathrm{MDA}, \uparrow 4-\mathrm{HDA}$ in brain and CSF & {$[79]$} \\
\hline & $\varnothing$ MDA, Ø 4-HDA in skeletal muscles and heart & \\
\hline Mice SOD1 G93A & $\begin{array}{l}\emptyset \mathrm{PC} \text { in brain, CSF, skeletal muscles, liver, heart } \\
\uparrow \mathrm{MDA}, \uparrow \mathrm{HNE} \text { in spinal cord }\end{array}$ & [81] \\
\hline Mice SOD1 G93A & $\uparrow$ In vivo trapped radical adducts & {$[76]$} \\
\hline Mice SOD1 G93A & $\uparrow 8-\mathrm{OHdG}$ in spinal cord & {$[80]$} \\
\hline Mice SOD1 G93A & $\uparrow \mathrm{PC}$ and $\uparrow 3-\mathrm{NT}$ in motor and sensory CTX & {$[78]$} \\
\hline Rats SOD1 G93A & $\uparrow$ Overnitrated proteins in mononuclear cells from peripheral blood & {$[83]$} \\
\hline Mice SOD1 G93A & $\uparrow 3$-NT in spinal cord in presymptomatic stage & {$[82]$} \\
\hline
\end{tabular}

$\downarrow$ decrease, $\uparrow$ increase, $\varnothing$ no changes, $n d$ not determined, 3-NT 3-nitrotyrosine, 4-HDA 4-hydroxyalkenal, 8$O H d G$ 8-hydroxy-2'-deoxyguanosine, $C S F$ cerebrospinal fluid, $C T X$ cortex, $M D A$ malondialdehyde, $P C$ protein carbonyl
H46R/H48Q mutations, the GSH level was not changed [88]. A recent study by Vargas et al. [88] showed that decreased GSH content accelerated neurological deficits in the SOD1 G93A mouse model. The mechanism of GSH reduction is linked to the nuclear transcription factor $\mathrm{Nrf} 2$ because its transfection into the SOD G93A mouse brain led to the upregulation of GSH synthesis in astrocytes and reduced the most apparent neurological and biochemical symptoms of the disease [89].

In animal models of ALS, motor neurons have displayed overexpression of Prx 2 and glutathione peroxidase- 1 (GPx1). The number of neurons containing Prx 2 and GPx1 decreased in the terminal stage of ALS [90], suggesting a breakdown of this redox system at the advanced stages of the disease. As discussed by Kato et al. [91], a possible reason for Prx2 and GPx1 breakdown might be related to the co-aggregation of these enzymes with mutant SOD1 and the exacerbation of mutant SOD1-mediated toxicity in neuronal Lewy body-like hyaline inclusions (LBHIs), which was shown in the spinal cords of transgenic rats [91]. Similarly, GPx3 protein levels in the serum of SOD1 H46R rats were increased in the pre-symptomatic stage and decreased gradually with disease progression [55]. However, another study did not reveal significance for the role of GPx in ALS [92], and further investigation is therefore necessary to clarify this problem.

Because enhanced SOD activity in ALS animal models remains enhanced in most of the disease stages and decreases only to the control level of non-transgenic mice in the end stage of the disease, this raises the question of whether these ALS animal models are suitable to study ALS antioxidant defense biomarkers because an ALS key enzyme, SOD, is decreased in ALS patients. These contradictory results, obtained in animals and humans, do not allow researchers to draw conclusions regarding the significance of these biomarkers in animal ALS models.

\section{Pharmacotherapeutic Strategy to Reduce OS}

Many substances possessing antioxidant properties have been proposed as ALS treatment strategies (Table 4). For example, coenzyme Q10 was shown recently to be unable to prolong survival when given after ALS onset [93]. As coenzyme Q10 is characterized by rather poor CNS availability (which possibly explains its small pharmacological effects), its reduced form, ubiquinol-10, has better bioavailability and antioxidant properties and was also investigated. However, similar to its parent drug, ubiquinol-10 did not prolong lifespan. Nevertheless, it was noted that poor CNS availability after oral dosing was observed in this study, which possibly explains the lack of pharmacological effects, similar to the case with its parent drug [93].

Creatine was the next drug that extended survival, but not age of onset, in ALS animals [94-96]. It has neuroprotective properties and buffers against ATP depletion in mitochondria. Its dysfunction can lead to ATP decreases, which may contribute to cell death [97]. Because mitochondrial swelling and vacuolization are among the earliest pathological features in ALS mice with the SOD mutations [98], creatine could be useful for protecting mitochondria and for disease treatment in such a preclinical model. In most studies, creatine was delivered in the diet as a 1 or $2 \%$ food supplementation. In addition to its effect of prolonging the lifespan in a mouse ALS model, creatine also improved motor performance [96] and provided protection from motor neuron loss at 120 days of age in these mice [98]. Moreover, creatine was shown to prevent the rise of 3-NT in the spinal cord and ROS production in the dialysate from microdialysis in ALS animals [98], and it also had a positive effect on weight retention [99]. However, one study found that creatine administration had no effect on the disturbed muscle function [100]. Moreover, coadministration of creatine with the cyclooxygenase- 2 inhibitors rofecoxib and celecoxib or of creatine with minocycline 
Table 4 Therapeutic trials with agents/drugs with antioxidant properties in ALS animal models

\begin{tabular}{|c|c|c|c|c|c|c|}
\hline Drug, dose, route of administration & Animal model & Therapy start after & $\begin{array}{l}\text { Changes in oxidative defense } \\
\text { and damage biomarkers }\end{array}$ & $\begin{array}{l}\text { Onset } \\
\text { change }\end{array}$ & $\begin{array}{l}\text { Survival } \\
\text { change }\end{array}$ & Reference \\
\hline Ubiquinol-10 800 mg/kg/day p.o. & Mice SOD1 G93A & Post-onset & nd & $\varnothing$ & $\varnothing$ & {$[93]$} \\
\hline Coenzyme Q10 800 mg/kg/day p.o. & Mice SOD1 G93A & Post-onset & nd & $\varnothing$ & $\varnothing$ & \\
\hline Creatine ( $2 \%$ in diet) & Mice SOD1 G93A & Pre-onset & nd & $\varnothing$ & $\uparrow$ & {$[95]$} \\
\hline $\begin{array}{l}\text { Creatine }(2 \% \text { in diet })+\text { celecoxib } \\
(12 \% \text { in diet })\end{array}$ & Mice SOD1 G93A & Pre-onset & nd & $\varnothing$ & $\uparrow$ & [94] \\
\hline $\begin{array}{l}\text { Creatine }(2 \% \text { in diet })+\text { rofecoxib } \\
(5 \% \text { in diet })\end{array}$ & Mice SOD1 G93A & Pre-onset & nd & $\varnothing$ & $\uparrow$ & \\
\hline $\begin{array}{l}\text { Creatine }(2 \% \text { in diet })+\text { minocycline } \\
\quad(22 \mathrm{mg} / \mathrm{kg} / \text { day i.p. })\end{array}$ & Mice SOD1 G93A & Pre-onset & nd & $\varnothing$ & $\uparrow$ & {$[96]$} \\
\hline $\begin{array}{l}\text { Vitamin E } 200 \text { IU/day, } 5 \text { days/week } \\
\text { for } 30 \text { days }\end{array}$ & Mice SOD1 G93A & Pre-onset & $\downarrow 8$-OHG in spinal cord & $\uparrow$ & $\varnothing$ & [103] \\
\hline $\begin{array}{l}\text { EUK-8 and EUK-134 } 33 \mathrm{mg} / \mathrm{kg} \text { i.p. } \\
3 \text { times a week }\end{array}$ & Mice SOD1 G93A & Pre-onset & $\downarrow \mathrm{MDA}, \downarrow \mathrm{PC}$ in spinal cord & $\varnothing$ & $\uparrow$ & {$[102]$} \\
\hline Edaravone $15 \mathrm{mg} / \mathrm{kg}$ i.p. & Mice SOD1 G93A & At symptoms onset & $\begin{array}{l}\downarrow \text { abnormal SOD1 deposition } \\
\text { in spinal cord }\end{array}$ & na & $\varnothing$ & {$[36]$} \\
\hline AEOL 101502.5 mg/kg i.p. & Mice SOD1 G93A & At symptoms onset & $\downarrow \mathrm{MDA}, \downarrow 3$-NT in spinal cord & na & $\uparrow$ & {$[108]$} \\
\hline \multirow{2}{*}{$\begin{array}{l}\text { Ammonium tetrathiomolybdate } \\
5 \mathrm{mg} / \mathrm{kg} \text { i.p. }\end{array}$} & \multirow[t]{2}{*}{ Mice SOD1 G93A } & Pre-onset & $\downarrow$ LPO,$\downarrow$ SOD in spinal cord & $\uparrow$ & $\uparrow$ & {$[86]$} \\
\hline & & Post-onset & nd & $\uparrow$ & $\uparrow$ & {$[105]$} \\
\hline Resveratrol $25 \mathrm{mg} / \mathrm{kg}$ i.p. & Mice SOD1 G93A & Pre-onset & $\downarrow$ MDA in spinal cord & $\uparrow$ & $\uparrow$ & {$[106]$} \\
\hline $\begin{array}{l}\text { Melatonin } 30 \mathrm{mg} / \mathrm{kg}, 10 \mu \mathrm{l} / \mathrm{g} \\
\text { body weight i.p. }\end{array}$ & Mice SOD1 G93A & Pre-onset & nd & $\uparrow$ & $\uparrow$ & [104] \\
\hline $\begin{array}{l}\text { Melatonin } 5 \mathrm{mg} / \mathrm{kg}, 2.5 \mathrm{mg} / \mathrm{kg} \\
\quad \text { or } 50 \mathrm{mg} / \mathrm{kg} \text { i.p. }\end{array}$ & Mice SOD1 G93A & Pre-onset & $\uparrow 4-\mathrm{HNE}, \uparrow \mathrm{SOD} 1$ in spinal cord & $\downarrow$ & $\downarrow$ & {$[107]$} \\
\hline
\end{tabular}

$\uparrow$ increase, $\downarrow$ decrease, 0 no change, $n a$ not applicable, $n d$ not determined, 3-NT- 3 nitrotyrosine, i.p. intraperitoneally, LPO lipid hydroperoxide, $M D A$ malondialdehyde, $P C$ protein carbonyls, $R O S$ reactive oxygen species, s.c. subcutaneously, $S O D$ superoxide dismutase

(a tetracycline antibiotic with neuroprotective and antiinflammatory effects) [101] may be even more beneficial for extending survival (even by $30 \%$ ) $[94,96]$.

Other antioxidants that extended survival in ALS mice include EUK-8 and EUK-134. In preclinical studies, these two synthetic SOD/CAT mimetics reduced the levels of OS, as measured by MDA, PC, and prolonged survival, but not disease onset, in ALS mice [102]. On the other hand, treatment with vitamin E significantly delayed ALS onset with no effect on survival but with a diminishing effect on 8-hydroxyguanine (8-OHG) levels in the spinal cord [103]. Drugs that shared both effects (ALS onset delay and lifespan extension) were melatonin, ammonium tetrathiomolybdate (a copper-chelating drug), and resveratrol (a substance that originates in plants and is found in highest amounts in red wine and the skin of red grapes) [86, 104-106]. However, in case of melatonin, the data were not clear as it was given in a dose range of 2.5$50 \mathrm{mg} / \mathrm{kg}$ intraperitoneal (i.p.) (in the same animal model) and also produced a surprisingly shortened survival, accelerated disease onset, enhanced lipid peroxidation in the spinal cord, and increased spinal motoneuron loss [107]. A possible reason for these results might be due, according to authors, to melatonin's effect on upregulating the gene expression of human toxic SOD1, which presumably overrides any of the anti-oxidant properties of melatonin. Such a hypothesis needs to be tested in future studies.

Other substances used in preclinical ALS models, i.e., resveratrol, which, when given before disease onset, decreased MDA levels [106], and ammonium tetrathiomolybdate, which decreased spinal SOD activity [86]. The latter compound also ameliorated ALS-like symptoms in SOD1 G93A mice, probably by chelating the copper ions from the Cys111 site in the SOD-1 enzyme, which is important because various SOD-1 mutations affect $\mathrm{Cu}$ and $\mathrm{Zn}$ metal-binding, thereby promoting toxic protein aggregation [86]. Moreover, successful effects were achieved from treatment with ammonium tetrathiomolybdate when it was given after disease onset, which is satisfactory because this regime of administration closely reflects clinical practice.

Edaravone and AEOL 10150 are recently studied drugs for ALS that were administered at ALS onset. Although edaravone did not prolong survival in an ALS mouse model, it diminished SOD1 deposition in the anterior horn of the spinal cord and slowed disease progression and motor neuron degeneration [36]. Another substance that gave more promising results is AEOL 10150, which, when administered to ALS mice, decreased 3-NT and MDA levels in the spinal cord, extended animal survival [108], provided better preservation 
of motor neuron architecture, and diminished the level of astrogliosis [108].

In conclusion, according to animal studies, antioxidants may become putative ALS therapies because many of them extend the lifespan and diminish OS in ALS animals. However, it must be remembered that many of them, when tested in humans, have not yet shown benefits for survival time and motor function amelioration.

\section{Anti-ALS Drugs that Modulate Oxidative Balance}

Riluzole was shown to extend the lifespan in mice in the SOD1 G93A ALS animal model, but it did not change the disease onset [109] or have a satisfactory effect on the latter parameter [110]. No studies concerning oxidative defense or oxidative damage biomarkers were conducted; however, in vitro studies showed that riluzole had antioxidant properties in cultured cortical neurons [111].

\section{Parkinson's Disease (ICD-10 G20)}

$\mathrm{PD}$ is a progressive degenerative disorder that is characterized by the loss of dopamine-producing neurons in the substantia nigra (SN) and by the presence of Lewy bodies in the SN and locus coeruleus. Clinical manifestations of PD include resting tremor, muscle rigidity, slowing of voluntary movements (bradykinesia), a tendency to fall (postural instability), and a mask-like facial expression [112]. The pathological hallmarks of PD, Lewy bodies, contain various proteins, including $\alpha$ synuclein, ubiquitin, Parkin, and neurofilaments.

PD occurs in sporadic (non-inherited; $90-95 \%$ cases) and familial (inherited; $5-10 \%$ cases) forms. Mutations in the $\alpha$ synuclein gene cause one of the familial forms of PD via autosomal dominant inheritance [113]. Recently, it was suggested that OS and imbalances between ROS/RNS and antioxidant defense mechanisms are linked to the etiology of PD.

\section{Clinical Studies}

\section{Oxidative Biomarkers}

Many studies have demonstrated the presence of OS and its markers in the brain and CSF in PD patients. Cholesterol lipid hydroperoxide and MDA were found to be up to 10-fold higher in $\mathrm{SN}$ in post-mortem brains of PD patients compared with other brain regions and age-matched controls [114]. In contrast, a recent paper demonstrated lower levels of MDA in the caudate nucleus and putamen and increased MDA levels in the frontal cortex in the post-mortem analyses of PD brains compared to healthy age-matched controls. Those results suggested that the non-SN regions, such as the caudate nucleus or the putamen, may have different compensatory mechanisms against OS could protect them from oxidative damage [115]. Moreover, HNE and acrolein-modified proteins were found in the neocortex and brainstem and in the SN, respectively, of PD patients [116-118]. According to in vitro studies, HNE modification of $\alpha$-synuclein has been shown to trigger oligomerization and fibrillization of unmodified $\alpha$-synuclein in the nervous system, which might lead to dopaminergic neuron injury. A recent observation suggests that HNE-modified proteins should be considered to be important players in PD pathophysiology [119].

Despite a number of studies supporting lipid peroxidation in the brains of $\mathrm{PD}$ patients, the levels of F2-isoprostanes were not elevated in the SN of PD patients [120], and the reason for this observed difference needs to be explained.

PCs were also found in PD patients' brains compared to age-matched controls [121]. PCs are present not only in the brain regions specific for PD (the SN, caudate nucleus, and putamen) but also in other brain areas not directly linked with PD. Because most PD patients are treated with L-DOPA, this observation may suggest that L-DOPA, the "gold standard" for PD therapy, may contribute to carbonyl formation because it was shown to have pro-oxidant properties in vitro [122]. Interestingly, brain regions from individuals with putative presymptomatic PD (incidental Lewy body disease) showed no $\mathrm{PC}$ rise. This information suggests that in PD, oxidative protein damage occurs late during disease progression and/or that L-DOPA treatment contributes to carbonyl formation [121]. Oxidative damage to proteins in PD also occurred through nitration, and 3-NT was found to be increased within Lewy bodies in the SN pars compacta (SNpc) of PD patients [123].

Another pathology found in PD brains is DNA and RNA damage $[124,125]$. The factors $8-\mathrm{OHG}$ and $8-\mathrm{OHdG}$ were elevated in various parts of the PD brain compared to controls; however, the most striking rise was detected in the SN [124, 125]. Similarly, increased levels of 8-OHG and 8-OHdG were observed in CSF $[126,127]$. However, these studies came to opposite conclusions with respect for the correlation between 8-OHG levels and disease duration.

In the CSF of living PD patients, enhanced levels of HNE and MDA have been shown as well [128-130], but different results were obtained by Shukla et al. [131]. Moreover, markers of oxidative damage in PD patients were also detected in the serum and urine [132-135], but their use as indicators of the course of the disease is far from being useful for clinical practice because the existing data are contradictory [136-138]. As has been suggested [136-138], these differences may be due to the variability in methods used to measure OS markers.

The results of many studies have demonstrated the presence of OS in the brain, CSF, serum, and urine of PD patients; however, none of the OS markers has been established as a specific biomarker for PD disease or as a marker for PD disease progression. 


\section{Antioxidant Defense Biomarkers}

PD is characterized by a selective loss of GSH in the SN ( $40 \%$ compared to control subjects) but not in other parts of the brain [139]. This decrease is one of the earliest biochemical changes that has been observed in the disease [140-143], and it results in a selective drop in mitochondrial complex I activity, another hallmark of PD [144]. On the other hand, a substantial rise in SOD levels has been observed in the SN and basal ganglia in PD patients [145], while no change in activities of CAT, GPx, and GR was found compared to agematched controls [145]. Another study showed some deficiency in GPx in the SN in Parkinsonian patients [146], but the weak (ca. $19 \%$ ) reduction in such a small number of patients $(n=11)$ cannot be considered to be conclusive. Another small pilot study in PD patients $(n=8)$ indicated a peripheral (in blood) increase in GSH/GSSG [147] when the patients went off of PD medications (dopamine receptor agonists) for $12 \mathrm{~h}$ in comparison to GSH/GSSG levels when they were on medications. This suggests that PD medications may play a disadvantageous role that leads to enhanced peripheral oxidative stress; however, the small sample size excludes a final conclusion [147].

\section{Pharmacological Strategies to Reduce OS}

Because there is an overwhelming amount of evidence showing that OS and NS in PD patients leads to an increase in pathological damage in the $\mathrm{SN}$, many approaches have been attempted to reduce ROS/RNS production. One of the possible strategies was to supplement GSH. As shown by Sechi et al. [148], in nine patients in the early stage of the disease [148], GSH (600 mg twice daily) administered intravenously for 30 days reduced (by $42 \%$ ) the clinical disability of PD patients, and this effect lasted for 2 4 months. Furthermore, a recent study of $N$-acetylcysteine $(150 \mathrm{mg} / \mathrm{kg})$, which is a GSH precursor, revealed an elevation in brain GSH levels and the blood GSH/GSSG ratio after 1-h of intravenous (i.v.) infusion [149]. Unfortunately, no results concerning the clinical status of PD patients have been described. However, $\mathrm{N}$-acetylcysteine, in a smaller dose $(70 \mathrm{mg} / \mathrm{kg}$ p.o., every $12 \mathrm{~h}$ over 2 days), produced negligible changes in GSH levels in the CSF and no immediate improvement to symptoms (according to the Unified Parkinson's Disease Rating Scale and the Montreal Cognitive Assessment) [150].

Magnetic resonance imaging (MRI) studies showed a rise in iron concentrations in the SN in PD patients [151]. Because iron can lead to ROS production in PD patients, an iron-binding compound, deferiprone, has been tested in a pilot study in PD patients (FAIRPARK trial, registered as ClinicalTrials.gov NCT00943748). Patients in early-stage PD who were on a stabilized dopamine regimen received deferiprone (30 mg/kg/day) for 12 months (early-start paradigm, $n=19$ ), while the other group received the drug for only 6 months, with the latter, shorter therapy starting 6 months later than the early-start paradigm (delayed-start paradigm, $n=18$ ) [152]. The earlier therapy start diminished SN iron deposits to a greater extent than the delayed-start paradigm and improved motor performance vs. placebo and vs. the delayed-start paradigm, according to the Unified Parkinson's Disease Rating Scale [152]. Moreover, in deferiprone-treated patients, GPx and SOD activity in the CSF increased, which supports the connection between the chelator treatment and the antioxidant response.

Vitamin E ( $\alpha$-tocopherol) was also suggested as a way to diminish the OS and to reduce clinical symptoms in PD. However, the clinical trial The Deprenyl and Tocopherol Antioxidant Therapy of Parkinsonism study (DATATOP study) revealed no evidence of any beneficial effect for $\alpha$-tocopherol $(2,000 \mathrm{IU} /$ day $)$ in either slowing functional declines or ameliorating the clinical features of Parkinson's disease. It is of note that no analysis of OS biomarkers was performed in that trial $[153,154]$. Since DATATOP, no clinical trials using vitamin $\mathrm{E}$ as a potential PD medication have been conducted. In fact, vitamin E was only used in PD clinical trials as a supplement for coenzyme Q10 or as a placebo [155] or a control [156].

Another potent antioxidant, coenzyme Q10 (1200 mg a day), in the first reported multicenter, randomized, placebocontrolled, and double-blind trial slowed functional declines compared to placebo [157]. Lower doses or different formulations of coenzyme Q10 displayed no symptomatic effects on midstage PD [158]. Recent clinical trial did not show a benefit for coenzyme Q10 (1,200 or 2,400 mg/day) in 600 patients in early-stage PD [155].

An early clinical study on creatine monohydrate (10 g/day for 12 months) in 67 subjects who were within 5 years of a PD diagnosis showed some positive results for treating behavioral difficulties [159], and an additional 18-month follow-up study confirmed this finding [160]. On the other hand, a smaller ( $n=$ 31 creatine PD group, $n=17$ placebo PD group), but longer, 2year clinical trial demonstrated that creatine had no effect on PD scores or dopamine transporter imaging [161]. In September 2013, the NINDS discontinued the NET-PD LS-1 study (phase III clinical trial with a total of 1,720 planned participants, ClinicalTrials.gov identifier: NCT00449865) that started in 2007 because the results obtained from a study of creatine used for the treatment of early stage PD did not demonstrate a statistically significant difference between the active substance and placebo [162].

In conclusion, although evidence for the link between OS and damage in PD is overwhelming, suggesting the potential efficacy of antioxidant drugs, most clinical trials have so far failed to support this statement. 


\section{Anti-Parkinsonian Strategies to Restore Oxidative Balance}

Administration of zonisamide, an anticonvulsant drug prescribed to treat resting tremor in PD, inhibited the rise of 8OHdG levels in the urine of PD patients. As the $8-\mathrm{OHdG}$ rise correlates with disease progression and aging, it can be presumed that zonisamide could be helpful in defending against OS-evoked DNA modifications in PD patients. Other drugs used for treatment of PD (i.e., L-DOPA, monoamine oxidase B (MAO-B) inhibitors, catechol-O-methyltransferase (COMT) inhibitors, and the dopamine receptor agonists ropinirole and pramipexole) have not shown such properties [163].

Interesting findings were reported in a study that measured GSH levels in venous blood in PD subjects who were on- and off-medication while performing acute physical exercises, because we know that this type of physical activity leads to GSH depletion and GSSG rise [164]. Surprisingly, the offmedication patients had a lower drop in GSH level than the on-medication group. This finding suggests that patients in the off-medication state handled acute stress better than those in the on-medication state, indicating that medication may impede the ability to tolerate acute OS [165]. Similar conclusions were obtained in a very recent study by Nikolova et al. [166], who observed a greater rise in PC and $8-\mathrm{OHdG}$ levels in the blood of PD patients who were treated with L-DOPA in comparison to untreated PD patients, demonstrating that administration of L-DOPA may cause greater OS than PD itself [166].

\section{Animal Studies}

\section{Oxidative Biomarkers}

The most popular animal models of PD include pharmacological (6-hydroxydopamine (6-OHDA), 1-methyl-4-phenyl-1,2, 3,6-tetrahydropyridine (MPTP), rotenone, and paraquat) as well as several genetic (with mutations in the $\alpha$-synuclein, PINK1, Parkin, or LRRK2 genes) models [167].

The 6-OHDA model (Table 5), wherein the toxin is injected directly into the SNpc, medial forebrain bundle, or striatum, was the first animal model of PD associated with dopaminergic neuronal death within the SNpc [168].

Another PD model utilizes MPTP, a highly lipophilic molecule that rapidly crosses the blood-brain barrier, leading to an irreversible and selective loss of dopaminergic neurons in the SN in non-human primates $[169,170]$ and in rodents [162, 171], although the latter species was less sensitive to MPTP than primates [172]. Other chemical models are based on an insecticide, rotenone, or paraquat, an herbicide. Rotenone, when given i.v. in a low dose to rats, produces selective degeneration of SN dopaminergic neurons that is accompanied by $\alpha$ synuclein-positive LB-like inclusions [173]. Paraquat is used less widely than MPTP, rotenone, or 6-OHDA models and is used instead as an addition to other toxic agents, such as the fungicide maneb [174]. It was reported to cause selective degeneration of nigrostriatal dopaminergic neurons in mice [175]. The mechanism of action of MPTP (a precursor form of the reactive metabolite $\mathrm{MPP}+$ ), rotenone, or paraquat is based on the inhibition of mitochondrial complex I, which leads to ROS production [167, 174, 175].

As has been demonstrated in numerous studies, OS is widely present in all of these toxin-based models (see Table 5). 6-OHDA, when injected into the striatum, increased MDA, HNE, PC, and 3-NT levels in this structure and increased TBARS in SN [176-179]. Similarly, in the MPTP and in the rotenone models, elevated levels of lipid peroxidation products [180-185] and oxidatively modified proteins $[185,186]$ were observed in various parts of the brain (striatum, cortex, SN, hippocampus, cerebellum, and midbrain). In addition to lipid damage, increased 3-NT levels were also detected following the use of MPTP in the SN, striatum, and ventral midbrain [181, 187]. MPTP or rotenone-treated animals also showed oxidatively modified RNA or DNA in the SN or striatum [185, 188, 189]. In the paraquat and maneb PD models, enhanced lipid peroxidation in the nigrostriatal areas of animal brains was also shown [190] (Table 5). A very recent report from Kumar et al. [175] demonstrated for the first time that $\alpha$-synuclein radical is formed in the midbrain in paraquat- and maneb-treated mice, indicating that radical formation is mediated by peroxynitrite and depends on both NADPH oxidase and iNOS. This interesting result regarding $\alpha$-synuclein radical formation was obtained by using the immuno-spin trapping method in combination with immunoprecipitation [175]. Moreover, it was noted that protein radicals such as $\alpha$ synuclein radical may trigger protein aggregation, which plays a causal role in dopaminergic neuronal death [175].

For review of genetic models and OS, see the excellent paper [167].

All toxin-based models share common characteristics, including the ability to produce ROS and further oxidative damage, which causes death in dopaminergic neurons and reflects part of the pathology observed in PD. Although all of those models have drawbacks, they are useful for testing neuroprotective therapies.

\section{Antioxidant Defense Biomarkers}

A characteristic shared feature observed in all toxin-based models is a drop in GSH level in key PD structures [177, 183-187, 191-196] (Table 5). Importantly, lower GSH levels make nigrostriatal neurons more susceptible to oxidative damage and further degeneration.

Studies using 6-OHDA also showed a reduction in activity by SOD, CAT, and glutathione $S$-transferase (GST) in striatum 
Table 5 Changes in OS and anti-OS defense biomarkers in toxin-based model of PD

\begin{tabular}{|c|c|c|c|c|c|}
\hline $\begin{array}{l}\text { Animal } \\
\text { model }\end{array}$ & $\begin{array}{l}\text { Route of administration, } \\
\text { dosage }\end{array}$ & Animal species & OS biomarkers & Oxidative defense biomarkers & Reference \\
\hline \multirow[t]{5}{*}{ 6-OHDA } & $\begin{array}{l}\text { Unilateral intra-STR inj. } \\
\qquad 10 \mu \mathrm{g} / 2 \mu \mathrm{l}\end{array}$ & Rats (Wistar) & $\uparrow T B A R S$ in SN & $\downarrow \mathrm{GSH}, \downarrow \mathrm{CAT} \downarrow \mathrm{SOD}$ in SN & [191] \\
\hline & $\begin{array}{l}\text { Bilateral intra-STR inj. } \\
\quad 10 \mu \mathrm{g} / 2 \mu \mathrm{l}\end{array}$ & Rats (Fischer) & $\uparrow H N E, \uparrow P C$ in STR & nd & [176] \\
\hline & $\begin{array}{l}\text { Unilateral intra-STR inj. } \\
\quad 300 \mu \mathrm{g} / 10 \mu \mathrm{l}\end{array}$ & $\begin{array}{l}\text { Rats (Sprague- } \\
\text { Dawley) }\end{array}$ & $\uparrow P C$ in STR & $\downarrow$ GSH and $\downarrow$ SOD in STR & {$[177]$} \\
\hline & Intra-STR inj. $8 \mathrm{mg} / 2 \mathrm{ml}$ & Rats (Wistar) & $\uparrow M D A$ in STR & $\downarrow S O D$, GST in STR & {$[178]$} \\
\hline & Intra-STR inj. $8 \mu \mathrm{g} / 4 \mu \mathrm{l}$ & Rats (Wistar) & $\uparrow 3-\mathrm{NT}, \uparrow H N E$ in STR & nd & [179] \\
\hline \multirow[t]{9}{*}{ МРTP } & $20 \mu \mathrm{l} / \mathrm{kg}$ intra-SN inj. & Rats (Wistar) & $\uparrow \mathrm{MDA}$ in $\mathrm{SN}$ & $\downarrow \mathrm{SOD}$ in $\mathrm{SN}$ & {$[180]$} \\
\hline & $25 \mathrm{mg} / \mathrm{kg} /$ day for 5 days & Mice (C57BL/6) & $\uparrow \mathrm{iNOS}, \uparrow \mathrm{HNE}, \uparrow 3-\mathrm{NT}$ in SN & nd & {$[181]$} \\
\hline & Intra-SN inj. & Rats (Wistar) & $\uparrow \mathrm{MDA}, \uparrow$ nitrate in STR and CTX & $\downarrow$ GSSH, $\downarrow$ CAT in STR and CTX & {$[182]$} \\
\hline & $24 \mathrm{mg} / \mathrm{kg} \mathrm{sc}$. for 6 days & Mice (C57BL/6) & $\uparrow \mathrm{MDA}$ in STR & $\downarrow \mathrm{GSH}, \downarrow \mathrm{SOD}, \downarrow \mathrm{GPx}, \downarrow \mathrm{CAT}$ in STR & [197] \\
\hline & $100 \mu \mathrm{g} / 1 \mu \mathrm{l}$, bilateral infusions & Rats (Wistar) & $\uparrow L P O$ in STR & $\downarrow \mathrm{GSH}, \uparrow \mathrm{SOD}$ in STR & [183] \\
\hline & $15 \mathrm{mg} / \mathrm{kg}$ s.c. for 3 days & Mice (C57BL/6) & $\uparrow 3-\mathrm{NT}, \uparrow \mathrm{HNE}$ in ventral midbrain & $\downarrow \mathrm{GSH}, \uparrow \mathrm{GSSG}$ in ventral midbrain & {$[187]$} \\
\hline & $\begin{array}{l}24 \mathrm{mg} / \mathrm{kg} \text { s.c. }(2 \text { times/day at } \\
12 \text {-h interval) for } 2 \text { days }\end{array}$ & Mice (C57BL/6) & $\uparrow 8-\mathrm{OHG}$ in SN & nd & {$[188]$} \\
\hline & $\begin{array}{l}20 \mathrm{mg} / \mathrm{kg} \text { i.p. } 3 \text { times at } 2-\mathrm{h} \\
\text { interval }\end{array}$ & Mice (C57BL/6J) & $\uparrow 8$-OHG in STR & nd & [189] \\
\hline & $\begin{array}{l}30 \mu \mathrm{g} / \mathrm{kg} \text { i.p. } 2 \text { times at } 16-\mathrm{h} \\
\text { interval }\end{array}$ & Mice (Balb/c) & nd & $\begin{array}{l}\downarrow G S H, \uparrow S O D \text { in } \mathrm{SN}, \text { nucleus } \\
\quad \text { caudate, and putamen }\end{array}$ & [192] \\
\hline \multirow[t]{7}{*}{ Rotenone } & $2.5 \mathrm{mg} / \mathrm{kg}$, i.p., for 10 days & Rats (Wistar) & nd & $\downarrow$ GSH in HIP, $\downarrow$ CAT in HIP and STR & [193] \\
\hline & One-sided intra-SN inj. $6 \mu \mathrm{g}$ & $\begin{array}{l}\text { Rats (Sprague- } \\
\text { Dawley) }\end{array}$ & nd & $\begin{array}{l}\downarrow \mathrm{GSH}, \uparrow \mathrm{Cu}-\mathrm{Zn} \mathrm{SOD}, \uparrow \mathrm{CAT} \text { in SN, } \\
\varnothing \mathrm{GSH}, \varnothing \mathrm{SOD} \text { in STR }\end{array}$ & [194] \\
\hline & $3 \mathrm{mg} / \mathrm{kg}$ i.p. for 30 days & Rats (Wistar) & nd & $\downarrow$ GSH, $\downarrow$ SOD in STR & [195] \\
\hline & $2 \mathrm{mg} / \mathrm{kg}$ s.c. for 35 days & $\begin{array}{l}\text { Rats (Sprague- } \\
\text { Dawley) }\end{array}$ & $\begin{array}{l}\uparrow \mathrm{TBARS}, \uparrow \mathrm{SAG} \text { in the midbrain } \\
\text { regions and cerebellum } \\
\text { and CTX }\end{array}$ & $\downarrow$ GSH, $\downarrow$ CAT in midbrain & [196] \\
\hline & $2 \mathrm{mg} / \mathrm{kg}$ s.c. for 35 days & $\begin{array}{l}\text { Rats (Sprague- } \\
\text { Dawley) }\end{array}$ & $\begin{array}{l}\uparrow \mathrm{MDA} \text { in midbrain regions and } \\
\text { cerebellum }\end{array}$ & $\begin{array}{l}\downarrow \mathrm{GSH}, \downarrow \mathrm{SOD} \text {, and } \uparrow \mathrm{CAT} \text { in midbrain } \\
\text { and CTX } \uparrow \mathrm{NO} \text { in midbrain }\end{array}$ & {$[184]$} \\
\hline & $1 \mathrm{mg} / \mathrm{kg}$ i.p for 3 weeks & $\begin{array}{l}\text { Mice (CFT- } \\
\text { Swiss) }\end{array}$ & $\uparrow P C$ in HIP, CTX, STR & $\begin{array}{l}\downarrow \text { GSH, } \downarrow \text { TT in HIP, } \downarrow \text { GPx, } \downarrow \text { CAT in } \\
\text { CTX and HIP, } \downarrow \text { SOD in CTX and } \\
\text { STR }\end{array}$ & {$[186]$} \\
\hline & $1.5 \mathrm{mg} / \mathrm{kg} / 48$ h s.c., 6 doses & Rats (Albino) & $\uparrow \mathrm{LPO}, \uparrow \mathrm{PC}, \downarrow \mathrm{mtDNA}$ in STR & $\downarrow \mathrm{GSH}, \downarrow \mathrm{SOD}$ in STR & {$[185]$} \\
\hline \multirow[t]{2}{*}{$\begin{array}{l}\text { Paraquat }+ \\
\text { maneb }\end{array}$} & $\begin{array}{l}\text { Paraquat }(10 \mathrm{mg} / \mathrm{kg})+\text { maneb } \\
\quad(30 \mathrm{mg} / \mathrm{kg}), \text { twice a week, } \\
\text { for } 9 \text { weeks }\end{array}$ & $\begin{array}{l}\text { Mice (Swiss } \\
\text { albino) }\end{array}$ & $\begin{array}{l}\uparrow \mathrm{MDA}, \uparrow \mathrm{NO} \text { in nigrostriatal } \\
\text { tissues }\end{array}$ & $\uparrow \mathrm{GST}$ in nigrostriatal regions & {$[190]$} \\
\hline & $\begin{array}{l}\text { Paraquat }(10 \mathrm{mg} / \mathrm{kg} \text {, i.p.), and } \\
\text { maneb }(30 \mathrm{mg} / \mathrm{kg} \text {, i.p. }) \\
\text { twice a week, for } 6 \text { weeks }\end{array}$ & Mice (C57BL6/J) & $\begin{array}{l}\alpha \text {-Synuclein radical in the } \\
\text { midbrain }\end{array}$ & nd & {$[175]$} \\
\hline
\end{tabular}

$\uparrow$ increase, $\downarrow$ decrease, $\varnothing$ no change, $n d$ not determined, 6-OHDA 6-hydroxydopamine, $C A T$ catalase, $C T X$ cortex, GPx glutathione peroxidase, GSH glutathione, GST glutathione $S$-transferase, HIP hippocampus, $H N E$ 4-hydroxynonenal, i.c.v. intracerebroventricular, intra-SN inj. intra-substantia nigra injection, $L P O$ lipid hydroperoxide, $M D A$ malonyldialdehyde, $M P T P$ 1-methyl-4-phenyl-1,2,3,6-tetrahydropyridine, $N O$ nitric oxide, $N O S$ nitric oxide synthetase, $P C$ protein carbonyl, $S A G$ superoxide anion generation, s.c. subcutaneous, $S N$ substantia nigra, $S O D$ superoxide dismutase, $S T R$ striatum, TBARS thiobarbituric acid reactive substances

and SN $[177,178,191]$. On the other hand, results from the MPTP model are inconclusive regarding SOD and CAT activity. Moreover, some of the MPTP studies showed increased SOD activity in the SN [192] and striatum [183], while others reported diminished SOD activity in these regions [180, 197]. These differences may have resulted from the use of different doses of the toxin, varied routes of drug administration (intracranial versus i.p. or s.c.), and different use of rodent species in the studies (see Table 5).
Similar to SOD activity, CAT activity cannot be considered a biomarker of OS in rodent PD models as its activity was both diminished [182, 191, 193, 194, 196, 197] and enhanced [184]. Moreover, GPx activity was diminished in striatum in an MPTP model [197], while GST activity was found to be elevated in a maneb and paraquat PD animal model [190] (Table 5).

All of these reports on the enhanced activities of SOD, CAT, and GST suggest the presence of mechanisms in brain 
areas that defend against exposure to PD toxin models. On the other hand, diminished activities or levels of antioxidant enzymes may indicate that these defense mechanisms were overcome and that the degeneration process had begun.

\section{Pharmacotherapeutic Strategy to Reduce OS}

Several agents, such as valproic acid [178] and melatonin [198], effectively reversed changes in antioxidant defense biomarkers and oxidative damage in the 6-OHDA rat model of PD (Table 6).
There are also data in the literature showing that other agents and drugs have antioxidant activity (i.e., ceftriaxone [182] and $N$-acetylcysteine [199], which decreased oxidative damage and/or enhanced antioxidant defense biomarkers in the striatum, cortex or SN in rodent MPTP models).

Ibuprofen (a non-steroidal anti-inflammatory drug [193]), acetyl-L-carnitine (a natural compound reported to prevent mitochondrial injury deriving from oxidative damage in vivo), $\alpha$-lipoic acid (given alone or in combination with acetyl-L-carnitine [185]), and centrophenoxine (a potent nootropic agent that acts as an antioxidant) [184] were demonstrated to enhance GSH levels and CAT and SOD activity and to

Table 6 Therapeutic trials with substances possessing antioxidant properties in PD animal models and their influence on changes of biomarkers of OS and anti-oxidative defense

\begin{tabular}{|c|c|c|c|c|}
\hline Model & $\begin{array}{l}\text { Biomarkers of OS and anti- } \\
\text { oxidative defense }\end{array}$ & $\begin{array}{l}\text { Drug and route of } \\
\text { administration }\end{array}$ & $\begin{array}{l}\text { Changes in biomarkers of OS and } \\
\text { anti-oxidative defense }\end{array}$ & Reference \\
\hline 6-OHDA, rats (Wistar) & $\begin{array}{l}\uparrow \mathrm{MDA}, \downarrow \mathrm{SOD}, \downarrow \mathrm{GPx}, \downarrow \mathrm{CAT} \\
\text { in STR }\end{array}$ & $\begin{array}{l}\text { Melatonin }(10 \mathrm{mg} / \mathrm{kg} \text { i.p. } \\
\text { for } 30 \text { days })\end{array}$ & $\downarrow \mathrm{MDA}, \uparrow \mathrm{SOD}, \uparrow \mathrm{GPx}, \uparrow \mathrm{CAT}$ in STR & [198] \\
\hline $\begin{array}{l}\text { 6-OHDA, } 8 \mathrm{mg} / 2 \mathrm{ml} \\
\text { intra-STR inj., rats }\end{array}$ & $\uparrow \mathrm{MDA}, \downarrow \mathrm{SOD}, \downarrow \mathrm{GST}$ in STR & $\begin{array}{l}\text { Valproic acid }(300 \mathrm{mg} / \mathrm{kg}) \\
\text { i.p. for } 10 \text { days }\end{array}$ & $\downarrow \mathrm{MDA}, \uparrow \mathrm{SOD}$ in STR & {$[178]$} \\
\hline MTPT intra-SN inj., rats & $\begin{array}{l}\downarrow \text { GSH, } \downarrow \text { CAT, } \uparrow \text { nitrate, } \uparrow \text { LPO } \\
\quad \text { in STR and CTX }\end{array}$ & $\begin{array}{l}\text { Ceftriaxone }(100 \mathrm{mg} / \mathrm{kg} \\
\text { or } 200 \mathrm{mg} / \mathrm{kg} \text { i.p. }) \\
\text { Ceftriaxone }(100 \mathrm{mg} / \mathrm{kg} \text { i.p. } \\
\text { and ropinirol } 1,5 \text { or } \\
3 \mathrm{mg} / \mathrm{kg} \text { i.p. })\end{array}$ & $\begin{array}{l}\uparrow \mathrm{GSH}, \uparrow \mathrm{CAT}, \downarrow \text { nitrate, } \downarrow \text { LPO in STR } \\
\text { and CTX } \\
\uparrow \mathrm{GSH}, \uparrow \mathrm{CAT}, \downarrow \text { nitrate, } \downarrow \text { LPO in STR } \\
\text { and }\end{array}$ & {$[182]$} \\
\hline MPTP mice $(\mathrm{C} 57 \mathrm{BL} / 6 \mathrm{~J})$, & $\begin{array}{l}\uparrow \mathrm{LPO}, \uparrow \mathrm{SOD}, \downarrow \mathrm{GPx}, \downarrow \mathrm{GSH} \\
\quad \text { in SNpc }\end{array}$ & $N$-acetylcysteine & $\downarrow \mathrm{LPO}, \downarrow \mathrm{SOD}, \uparrow \mathrm{GPx}, \uparrow \mathrm{GSH}$ in SNpc & [199] \\
\hline $\begin{array}{l}\text { Rotenone, } 2.5 \mathrm{mg} / \mathrm{kg} \text {, i.p. } \\
\quad \text { for } 10 \text { days, rats }\end{array}$ & $\begin{array}{l}\downarrow \text { GSH in HIP, } \downarrow \text { CAT in HIP } \\
\text { and STR }\end{array}$ & $\begin{array}{l}\text { Ibuprofen }(15 \mathrm{mg} / \mathrm{kg} \text {, p.o. } \\
22 \text { days post } 10 \text {-day } \\
\text { rotenone treatment })\end{array}$ & $\begin{array}{l}\uparrow \mathrm{GSH} \text { in HIP vs. rotenone group, } \uparrow \mathrm{CAT} \\
\text { in HIP and STR vs. rotenone group }\end{array}$ & [193] \\
\hline $\begin{array}{l}\text { Rotenone, } 3 \mathrm{mg} / \mathrm{kg} \text { i.p. } \\
\text { for } 30 \text { days, rats }\end{array}$ & $\downarrow \mathrm{GSH}, \downarrow \mathrm{SOD}, \uparrow \mathrm{MDA}$ in STR & $\begin{array}{l}\text { Lycopene }(10 \mathrm{mg} / \mathrm{kg}, \mathrm{p} . \mathrm{o} . \\
\text { for } 30 \text { days, a combined } \\
\text { treatment with rotenone })\end{array}$ & $\uparrow \mathrm{GSH}, \downarrow \mathrm{SOD}, \uparrow \mathrm{CAT}$ in HIP, STR & {$[195]$} \\
\hline $\begin{array}{l}\text { Rotenone, } 1 \mathrm{mg} / \mathrm{kg} / \text { day } \\
\text { i.p. for } 3 \text { weeks, mice } \\
\text { (CFT-Swiss) }\end{array}$ & $\begin{array}{l}\downarrow \text { GSH in HIP, } \downarrow \text { TT in HIP, } \downarrow \text { GPx, } \\
\downarrow \text { CAT in CTX and HIP, } \downarrow \text { SOD } \\
\text { in CTX and STR, } \uparrow P C \text { in HIP, } \\
\text { CTX, STR }\end{array}$ & $\begin{array}{l}\text { TSE_-aqueous extract of } \\
\text { tomato seeds }(100 \mathrm{mg} / \\
\mathrm{kg} \text { p.o. for } 3 \text { weeks, } 1 \mathrm{~h} \\
\text { before rotenone injection) }\end{array}$ & $\begin{array}{c}\uparrow \mathrm{GSH}, \uparrow \mathrm{CAT}, \uparrow \mathrm{TT} \text { in HIP, } \downarrow \mathrm{PC} \text { in STR, } \\
\uparrow \mathrm{SOD} \text { in CTX and STR, } \uparrow \mathrm{GPx} \text { in } \\
\text { CTX and HIP } \downarrow \mathrm{PC} \text { in STR, } \uparrow \mathrm{SOD} \\
\text { in CTX and STR }\end{array}$ & {$[186]$} \\
\hline $\begin{array}{l}\text { Rotenone, } 1.5 \mathrm{mg} / \mathrm{kg} / 48 \\
\mathrm{~h} / 6 \text { doses, s.c., rats } \\
\text { (Albino) }\end{array}$ & $\begin{array}{l}\uparrow \mathrm{LPO}, \uparrow \mathrm{PC}, \downarrow \mathrm{GSH}, \mathrm{SOD}, \downarrow \\
\text { mtDNA in STR }\end{array}$ & $\begin{array}{l}\text { Acetyl-L-carnitine }(100 \mathrm{mg} / \\
\mathrm{kg} / \mathrm{day}, \mathrm{p} . \mathrm{o} .), \alpha \text {-lipoic acid } \\
(50 \mathrm{mg} / \mathrm{kg} / \text { day, p.o. }) \text { or } \\
\text { their combination }\end{array}$ & $\begin{array}{l}\downarrow \mathrm{LPO}, \uparrow \mathrm{GSH}, \uparrow \mathrm{SOD} \text {, and } \uparrow \mathrm{mtDNA} \text { in } \\
\text { STR after each drug alone or after } \\
\text { combination, } \downarrow \mathrm{PC}, \uparrow \mathrm{CAT} \text { in STR } \\
\text { only after combination }\end{array}$ & {$[185]$} \\
\hline $\begin{array}{l}\text { Rotenone, } 2 \mathrm{mg} / \mathrm{kg} \text { s.c. } \\
\text { for } 35 \text { days, rats } \\
\text { (Spraque- Dawley) }\end{array}$ & $\begin{array}{l}\uparrow \mathrm{MDA} \text { in midbrain and } \\
\text { cerebellum, } \downarrow \text { GSH, } \downarrow \text { SOD, } \\
\text { and } \uparrow \mathrm{CAT} \text { in midbrain and } \\
\mathrm{CTX}, \uparrow \mathrm{NO} \text { in midbrain }\end{array}$ & $\begin{array}{l}\text { Centrophenoxine }(100 \mathrm{mg} / \mathrm{kg} \\
\text { i.p., co-administration with } \\
\text { rotenone for } 35 \text { days })\end{array}$ & $\begin{array}{l}\downarrow \mathrm{MDA} \text { in midbrain and cerebellum, } \uparrow \\
\text { GSH, } \uparrow \mathrm{SOD}, \uparrow \mathrm{CAT} \text { in midbrain and } \\
\text { CTX, } \downarrow \text { NO in midbrain }\end{array}$ & {$[184]$} \\
\hline $\begin{array}{l}\text { Maneb }(30 \mathrm{mg} / \mathrm{kg}) \text { and } \\
\text { paraquat }(10 \mathrm{mg} / \mathrm{kg}) \\
\text { i.p. twice a week } \\
\text { for } 9 \text { weeks, mice } \\
\text { (Swiss albino) }\end{array}$ & $\begin{array}{c}\uparrow \mathrm{MDA}, \uparrow \mathrm{NO}, \uparrow \mathrm{GST} \text { in } \\
\text { nigrostriatal regions }\end{array}$ & $\begin{array}{l}\text { Silymarin }(40 \mathrm{mg} / \mathrm{kg} \text { i.p. for } \\
9 \text { weeks), maneb, and } \\
\text { paraquat were administered } \\
2 \mathrm{~h} \text { after this injection } \\
\text { Melatonin }(30 \mathrm{mg} / \mathrm{kg} \text { i.p. for } \\
9 \text { weeks, maneb and } \\
\text { paraquat were administered } \\
2 \mathrm{~h} \text { after this injection }\end{array}$ & $\begin{array}{l}\downarrow \mathrm{MDA}, \downarrow N O \text {, and } \downarrow \text { GST in nigrostriatal } \\
\text { tissues }\end{array}$ & {$[190]$} \\
\hline
\end{tabular}

$\uparrow$ increase, $\downarrow$ decrease, $n d$ not determined, CAT catalase, CTX cortex, GPx glutathione peroxidase, GSH glutathione, GST glutathione transferase, GST glutathione $S$-transferase, HIP hippocampus, HNE 4-hydroxynonenal, i.c.v. intracerebroventricular, i.p. intraperitoneal, intra-SNc inj. intra-substantia nigra injection, intra-STR inj. intrastriatal injection, $L P O$ lipid hydroperoxide, $M D A$ malonyldialdehyde, $N O$ nitric oxide, $N O S$ nitric oxide synthetase, $P C$ protein carbonyl, s.c. subcutaneous, $S N$ substantia nigra, $S N p c$ substantia nigra pars compacta, $S O D$ superoxide dismutase, $S T R$ striatum, TBARS thiobarbituric acid reactive substances, $T T$ total thiol 
decrease lipid peroxidation in investigated brain regions in a rat rotenone model (Table 6).

Prevention of oxidative damage and the presence of antioxidant defense biomarkers have been documented following treatment with natural compounds, such as lycopene [195], aqueous extract of tomato seeds (TSE) [186], and melatonin [190].

Many different agents may improve antioxidant brain status in different PD models. However, it should be noted that most of these agents were given before or concomitantly with rotenone, MPTP, or other PD-causing toxins. To definitively answer whether these agents can also show efficacy in reducing the consequences of exposure to prior administration of PD-inducing toxins, further studies are required. This is especially true because the latter type of drug administration would be a better model for evaluating any pharmacological strategy for reducing OS in PD patients.

\section{Anti-Parkinsonian Drugs that Modulate Oxidative Balance}

Most anti-parkinsonian drugs may improve brain antioxidant status in PD preclinical tests (Table 7). Ropinirole, a secondgeneration, non-ergoline dopamine receptor agonist with D2like receptor selectivity and a chemical structure similar to that of dopamine was found to enhance GSH levels and CAT [182] activity and to diminish nitrate levels [182] in the striatum in MPTP-lesioned animals.

Other anti-parkinsonian drugs, such as selegiline (a selective irreversible MAO-B inhibitor) [196], deferoxamine [177], and pramipexole (a non-ergoline dopamine agonist) [200], increased GSH levels in the striatum, SN, or cortex. Deferoxamine also decreased a protein oxidative damage biomarker [177] and enhanced SOD activity in the striatum, while selegiline reduced superoxide anion generation (SAG) and increased CAT activity in midbrain regions and the cortex [196]. Interestingly, L-DOPA, the most commonly used drug in PD treatment, did not restore the reduced GSH levels in the SN in the MPTP mouse model [200].

The above studies suggest that antiparkinsonian drugs, with the exception of L-DOPA, display some antioxidant properties, which may be considered as part of their mode of action and efficacy in PD treatment.

\section{Alzheimer's Disease (ICD-10 G30)}

$\mathrm{AD}$ is the most common neurodegenerative disease and is characterized by memory loss, dysfunctions in cognitive abilities (e.g., executive function, attention, language, and visuospatial skills), confusion, aggression, and mood swings [113, 201] and leads to death within 5 to 9 years after the diagnosis [202].

The pathogenesis of AD is not yet clearly understood. The aggregation of extracellular insoluble protein plaques (composed of beta amyloid $(\mathrm{A} \beta)$ ) and intracellular neurofibrillary tangles (NFTs, composed of tau protein) are critical hallmarks of $\mathrm{AD}[113,201]$. However, many ongoing pathological processes lead to regional neuron loss, beginning in the medial temporal lobe [201] and following in other brain regions, such as the hippocampus and cerebral cortex [113].

Many clinical trials and animal studies have recognized free radicals as mediators of injury in $\mathrm{AD}$ patients and $\mathrm{AD}$ models.

Table 7 Therapeutic trials with anti-parkinsonian drugs in PD animal models and their influence on biomarkers of OS and of anti-oxidative defense

\begin{tabular}{|c|c|c|c|c|}
\hline Model & Oxidative defense biomarkers & Drug & $\begin{array}{l}\text { Changes in oxidative } \\
\text { defense biomarkers }\end{array}$ & Reference \\
\hline $\begin{array}{l}\text { MPTP } 25 \mathrm{mg} / \mathrm{kg} \text { i.p. for } \\
5 \text { days administered to } \\
6 \mathrm{C} 57 \mathrm{BL} / 6 \mathrm{~J} \text { mouse }\end{array}$ & $\downarrow \mathrm{GSH}$ in $\mathrm{SN}$ & $\begin{array}{l}\text { L-DOPA }(200 \mathrm{mg} / \mathrm{kg} \text { i.p. } 2 \text { injections/ } \\
\text { day for } 4 \text { weeks, co-administration } \\
\text { with MPTP }\end{array}$ & $\varnothing \mathrm{GSH}$ in $\mathrm{SN}$ & [200] \\
\hline $\begin{array}{l}\text { MPTP } 1 \mu \mathrm{mol} / 2 \mu \mathrm{lintra}- \\
\text { SN administered to } \\
\text { Wistar rat }\end{array}$ & $\begin{array}{c}\downarrow \mathrm{GSH}, \downarrow \mathrm{CAT}, \uparrow \text { nitrate, and } \\
\uparrow \mathrm{LPO} \text { in STR and CTX }\end{array}$ & $\begin{array}{l}\text { Ropinirole } 1,5 \text {, or } 3 \mathrm{mg} / \mathrm{kg} \text { i.p. for } \\
14 \text { days, after MPTP treatment }\end{array}$ & $\begin{array}{l}\uparrow \mathrm{GSH}, \uparrow \mathrm{CAT}, \downarrow \text { nitrate } \\
\text { (only } 1.5 \mathrm{mg} / \mathrm{kg} \text { ) } \\
\text { in STR and CTX }\end{array}$ & {$[182]$} \\
\hline $\begin{array}{l}\text { MPTP } 25 \mathrm{mg} / \mathrm{kg} \text { i.p. for } \\
5 \text { days administered to } \\
\text { C57BL } / 6 \mathrm{~J} \text { mouse }\end{array}$ & $\downarrow \mathrm{GSH}$ in $\mathrm{SN}$ & $\begin{array}{l}\text { Pramipexole } 1 \mathrm{mg} / \mathrm{kg} \text { i.p. } 2 \text { injections/ } \\
\text { day for } 4 \text { weeks, co-administration } \\
\text { with MPTP }\end{array}$ & $\uparrow \mathrm{GSH}$ in $\mathrm{SN}$ & [200] \\
\hline $\begin{array}{l}\text { Rotenone } 2 \mathrm{mg} / \mathrm{kg} \text { s.c. } \\
35 \text { days administered } \\
\text { to Sprague-Dawley rats }\end{array}$ & $\begin{array}{l}\uparrow \mathrm{TBARS}, \uparrow \mathrm{SAG} \text { in midbrain } \\
\text { regions and cerebellum, } \\
\downarrow \mathrm{GSH} \text { and } \downarrow \text { CAT in } \\
\text { midbrain regions and CTX }\end{array}$ & $\begin{array}{l}\text { Deprenyl } 10 \mathrm{mg} / \mathrm{kg} \text { p.o. co- } \\
\text { administration with rotenone } \\
\text { for } 35 \text { days }\end{array}$ & $\begin{array}{l}\downarrow \text { TBARS, } \downarrow \text { SAG in } \\
\text { midbrain; } \uparrow \mathrm{GSH}, \uparrow \\
\text { CAT in midbrain } \\
\text { and CTX }\end{array}$ & [196] \\
\hline $\begin{array}{l}\text { 6-OHDA } 300 \mu \mathrm{g} / 10 \mu \mathrm{l} \\
\text { unilateral intra-STR inj. } \\
\text { administered to Sprague- } \\
\text { Dawley rats }\end{array}$ & $\uparrow \mathrm{PC}, \downarrow \mathrm{GSH}$, and $\downarrow \mathrm{SOD}$ in STR & $\begin{array}{l}\text { Deferoxamine } 50 \mathrm{mg} / \mathrm{kg} \text { p.o. for } \\
14 \text { days, co-administration with } \\
\text { 6-OHDA }\end{array}$ & $\begin{array}{l}\downarrow \mathrm{PC}, \uparrow \mathrm{GSH} \text {, and } \uparrow \mathrm{SOD} \\
\quad \text { in STR }\end{array}$ & {$[177]$} \\
\hline
\end{tabular}

$\uparrow$ increase, $\downarrow$ decrease, $\varnothing$ no change, na not applicable, 6-OHDA 6-hydroxydopamine, $C A T$ catalase, $C T X$ cortex, GSH glutathione, i.p. intraperitoneal, $L P O$ lipid hydroperoxide, MPTP 1-methyl-4-phenyl-1,2,3,6-tetrahydropyridine, $P C$ protein carbonyl, s.c. subcutaneous, $S A G$ superoxide anion generation, $S O D$ superoxide dismutase, STR striatum, TBARS thiobarbituric acid reactive substances 


\section{Clinical Studies}

\section{Oxidative Biomarkers}

The first report of the involvement of OS in AD pathology came from a paper by Martins et al. [203], in which elevated activities of glucose-6-phosphate dehydrogenase and 6phosphogluconate dehydrogenase were documented in postmortem studies of brains of AD patients compared to agematched controls [203]. The latter increase was proposed to be a response to enhanced brain peroxide metabolism.

Other post-mortem studies on brains and CSF from AD patients showed ROS-mediated injuries. For instance, AD patients had increased levels of MDA and HNE, iso- and neuroprostanes, and acrolein compared to controls [204]. It was suggested that these peroxidated lipids formed adducts with proteins and that they might thereby play a role in $\mathrm{AD}$ pathogenesis [201].

In addition to lipids, protein damage due to OS has also been reported in AD. In fact, increased PC levels in the frontal and parietal cortices and the hippocampus were found in postmortem studies of the brains of AD patients, while PC was absent in the cerebellum, where no AD pathology was present [205]. Furthermore, evidence of oxidative DNA modification was found in $\mathrm{AD}$ patients as an increase in $8-\mathrm{OHG}$ in human brain homogenates [201].

In $\mathrm{AD}$ patients, ROS production seems to be enhanced; furthermore, increases in RNS were also detected. Such evidence of RNS modification was identified both in astrocytes and in neurons in $\mathrm{AD}$ patient brains examined post-mortem [206]. The changes in astrocytes were found to co-localize with an increase in iNOS, eNOS, and nNOS expression. The latter increases were noted specifically in cortical pyramidal cells [206]. In another study, increased expression of iNOS and eNOS was observed to be directly associated with $A \beta$ deposits, showing that beta amyloid might induce NOS to produce NO, which might lead to 3-NT formation [207].

The presence of 3-NT was also reported in the cerebral blood vessels of AD patients post-mortem [206]. These findings were associated with reduced NO bioavailability in plasma and further hypoperfusion in $\mathrm{AD}$ patients because $\mathrm{NO}$ promotes vascular smooth muscle relaxation and thereby regulates blood flow. As was reported in recent studies, enhanced $\mathrm{NO}$ production is a likely cause of production of $\mathrm{ONOO}^{-}$ [208, 209].

Another set of oxidative damage biomarkers, 8-OHdG and 8-OHG, were elevated in AD ventricular CSF [210] and in brains in both mitochondrial and nuclear DNA compared with age-matched controls [211].

Consistent data showing enhanced levels of MDA, HNE, iso- and neuroprostanes, acrolein, $\mathrm{PC}, 8-\mathrm{OHG}, 8-\mathrm{OHdG}$, and 3-NT in the CNS of AD patients can be considered to be proof that OS and NOS are significant contributors to brain damage.

\section{Antioxidant Defense Biomarkers}

Pivotal antioxidant enzymes, including GPx, CAT, and SOD, display changed levels in the brains of AD patients [212, 213]. However, the data are not consistent. For instance, elevated levels of antioxidant enzymes (mainly SOD) in the hippocampus and amygdala of AD patients have been reported [208]. On the other hand, in AD patients, decreased levels of SOD, GPx, and CAT were found in the frontal and temporal cortex [214], while decreases in GSH were observed in the brain and erythrocytes of AD patients [212, 213]. Evidence in support of changes in antioxidant enzymes comes from a recent study that identified genetic polymorphisms in the GPx-1 and GST genes that were positive risk factors for $\operatorname{AD}[215,216]$.

The GSH levels were reduced not only in AD but also in mild cognitive impairment (MCI), which is considered to be a preclinical stage of AD [217]. MCI patients also showed a decreased GSH/GSSG ratio and a reduction in SOD and GST activity in the hippocampus compared to age-matched controls [218], which suggests that alterations in GSH metabolism may be considered as an early biomarker of AD onset.

The plasma levels of antioxidants, such as albumin, bilirubin, uric acid, lycopene, vitamin A, vitamin C, and vitamin $\mathrm{E}$, are decreased in AD patients [219, 220], although there are some reports indicating the opposite direction of these changes [221]. Differences in results might be caused by measurement of antioxidants at different disease stages (fully developed disease vs. subclinical stage of the disease) [219-221].

\section{Pharmacological Strategy to Reduce OS}

As $\mathrm{OS}$ is present in $\mathrm{AD}$ patients, some clinical studies have aimed to test the ability of antioxidant substances to diminish ROS production and to alleviate or to slow the course of the disorder (Table 8).

Most studies on the effects of the administration of vitamins that possess antioxidant activity have provided inconclusive information showing that they diminished lipid peroxidation in CSF but had no positive effects on cognitive or functional aspects. For example, AD patients taking cholinesterase inhibitors and vitamin C (1,000 mg/day) or vitamin E (400 IU/ day) supplements for 1 year showed decreased CSF oxidation, but no difference in cognition was observed [222]. Similarly, 16-week treatment with a combination of vitamin $\mathrm{E}$ (800 IU/ day), vitamin C (500 mg/day) and $\alpha$-lipoic acid ( $900 \mathrm{mg} /$ day) decreased CSF F2-isoprostane levels, which suggested a reduction of OS in the brain, but surprisingly, this therapy accelerated cognitive decline (according to Mini-Mental State Examination scores), leading to the conclusion that a combination of antioxidants should not be used for AD therapy [223]. On the other hand, very recent results from a large, clinical, double-blind, randomized trial (TEAM-AD VA, NCT00235716) showed that a much larger dose of vitamin 
Table 8 Clinical trials with substances/drugs with antioxidant properties in AD patients

\begin{tabular}{|c|c|c|c|}
\hline Antioxidant & $\begin{array}{l}\text { Duration } \\
\text { of therapy }\end{array}$ & Oxidative damage biomarker change & Reference \\
\hline $\begin{array}{l}\text { Vitamin E ( } \alpha \text {-tocopherol, } 800 \mathrm{IU} / \text { day })+ \text { vitamin C (500 mg/day) } \\
+\alpha \text {-lipoic acid ( } 900 \mathrm{mg} / \text { day })\end{array}$ & 16 weeks & $\downarrow$ F2-isoprostane in CSF & [223] \\
\hline Coenzyme Q10 (400 mg ×3 times/day) & 16 weeks & $\varnothing \mathrm{F} 2$-isoprostane in CSF & {$[223]$} \\
\hline$\omega-3$ (3 g/day contained $675 \mathrm{mg}$ DHA and $975 \mathrm{mg}$ EPA) & 12 months & $\varnothing \mathrm{F}$ 2-isoprostane in urine, $\varnothing \mathrm{PC}$ in plasma & [228] \\
\hline $\begin{array}{l}\omega-3+\alpha \text {-lipoic acid }(\omega-3,3 \mathrm{~g} / \text { day contained } 675 \mathrm{mg} \text { DHA and } \\
975 \mathrm{mg} \text { EPA }+\alpha \text {-lipoic acid, } 600 \mathrm{mg} / \text { day in one tablet })\end{array}$ & 12 months & $\varnothing \mathrm{F}$ 2-isoprostane in urine $\varnothing \mathrm{PC}$ in plasma & {$[228]$} \\
\hline Vitamin C (1,000 mg/day) + vitamin E (400 IU/day) & 12 months & $\downarrow$ oxidation of CSF & {$[222]$} \\
\hline Curcumin ( 1 or $4 \mathrm{~g} /$ day) & 6 months & $\varnothing$ F2-isoprostane in plasma & {$[230]$} \\
\hline Curcuminoids ( 2 or 4 g/day) & 24 weeks & $\varnothing \mathrm{F} 2$-isoprostane in CSF & [229] \\
\hline Idebenone $(120,240$, or 360 mg/day) & 12 months & nd & {$[225]$} \\
\hline
\end{tabular}

$\downarrow$ decrease, $\varnothing$ no change, $n d$ not determined, $C S F$ cerebrospinal fluid, $D H E$ docosahexaenoic acid, EPA eicosapentaenoic acid, $\omega-3$ omega-3 fatty acids

$\mathrm{E}(2,000 \mathrm{IU} /$ day $)$ than was used in previous trials resulted in a slower functional decline compared with placebo in mild to moderate AD [224]. Although the latter study suggests that vitamin $\mathrm{E}$ can have a positive influence on $\mathrm{AD}$, no OS biomarkers have been measured in parallel in the $\mathrm{AD}$ patients who participated in that trial, which limits the final conclusion.

Administration of other antioxidants, including coenzyme Q10 as well as its synthetic analogue, idebenone (which possesses a better ability to pass the blood-brain barrier), in $\mathrm{AD}$ patients did not provide any positive results with regards to the volume of ROS-dependent tissue damage or cognitive function improvements [223, 225]. Similarly, administration of omega-3 ( $\omega-3)$ fatty acids also did not yield a positive outcome for slowing the rate of decline of cognitive (Mental State Examination (MMSE); Alzheimer's Disease Assessment Scale - cognitive subscale) or functional (Activities of Daily Living/Instrumental Activities of Daily Living) abilities [226, 227]. Different results were reported in a recent study, where 12-month $\omega-3$ fatty acid supplementation caused a delay in progression of functional impairment in $\mathrm{AD}$ patients, while combined supplementation of $\omega-3$ and $\alpha$-lipoic acid resulted in slowing global cognitive declines (MMSE) [228]. Although positive cognitive outcomes were obtained, no changes after $\omega$-3 or $\omega-3$ plus $\alpha$-lipoic acid supplementation were observed in OS biomarkers, suggesting a different mechanism for their actions that lead to improved cognitive and functional measures [228].

Curcumin, which is a natural polyphenolic compound and an in vitro blocker of $A \beta$ aggregation, did not diminish the enhancement of F2-isoprostane levels in the CSF [229] or plasma [230], or the $A \beta_{1-40}$ level in plasma [230], and it did not ameliorate neuropsychological test results in $\mathrm{AD}$ patients $[229,230]$. As suggested by Ringman et al. [229], low bioavailability of the drug and low plasma levels due to poor uptake from the gastrointestinal tract might be the reasons for its lack of efficacy in the latter studies. There is some hope that curcumin efficacy can be improved through the use of its lipidated forms, which are predicted to have better uptake compared to the nonlipidated form [231]. In a study in healthy, middle-aged volunteers, the lipidated form of curcumin ( $80 \mathrm{mg} /$ day) decreased $A \beta_{1-40}$ levels in plasma [231], suggesting that further trials using lipidated curcumin should be considered in $\mathrm{AD}$ patients.

More promising results came from a study using resveratrol. The Copenhagen City Heart Study reported that monthly or weekly consumption of red wine was associated with a lower risk of dementia [232]. The clinical study NCT01504854, also called the "Phase II Study to Evaluate the Impact on Biomarkers of Resveratrol Treatment in Patients with Mild to Moderate AD," was undertaken in 2011 to evaluate the effectiveness of resveratrol for changing AD CSF biomarkers (total tau, $\mathrm{A} \beta_{42}, \mathrm{~A} \beta_{40}$, and phospho-tau181), the effect of resveratrol treatment on hippocampal atrophy and regional cortical thinning, and the influence of resveratrol administration on the outcomes of several clinical scales used to assess the severity of dementia [233]. According to the report at http://clinicaltrials.gov record (accessed 15 May 2015), the study has been completed, but no results have yet been published.

\section{Anti-Alzheimer's Disease Therapy and Oxidative Balance}

Acetylcholinesterase (AChE) inhibitors (donepezil, rivastigmine, galantamine, and tacrine) and the NMDA receptor antagonist memantine are the most commonly used drugs in AD pharmacotherapy. Only some clinical studies that have investigated the influence of these drugs on oxidative balance in AD patients are currently available (see Table 9). One of them showed no positive effects of AChE inhibitors on OS parameters (CAT and GR levels) in the blood of AD patients compared with AD drug-naïve patients [234]. In another study, donepezil enhanced GSH levels, while rivastigmine diminished advanced glycation end products (AGEs) in the plasma of $\mathrm{AD}$ patients. However, other examined parameters, namely total 
Table 9 Clinical trials of anti-Alzheimer drugs and their influence on OS biomarkers

\begin{tabular}{lll}
\hline Anti-Alzheimer medication (dose) & Duration of therapy & Oxidative damage biomarker change \\
\hline Donepezil (10 mg/day) & $\geq 24$ months & $\uparrow$ GSH, Ø AGEs, TAC, PC in plasma \\
Tivastigmine (9.5 mg/day) & $\geq 24$ months & $\downarrow$ AGEs, Ø GSH, TAC, PC in plasma \\
Donepezil (10 mg/day) + memantine $(20 \mathrm{mg} / \mathrm{kg})$ & $\geq 24$ months & $\varnothing$ GSH, TAC, PC, AGEs in plasma \\
Memantine (20 mg/day) & For 6 months & $\downarrow$ oxidation rates of lipids in plasma \\
\hline
\end{tabular}

$\uparrow$ increase, $\downarrow$ decrease, $\varnothing$ no change, $A G E s$ advanced glycation end products, GSH glutathione, $P C$ protein carbonyl, $T A C$ total antioxidant capacity

antioxidant capacity (TAC) and PC, have not been improved by those drugs [235]. Combined therapy with memantine and donepezil failed to improve GSH, TAC, PC, or AGEs [235]. A very recent study revealed that 6-month treatment with memantine decreased the oxidation rate of plasma lipids in $\mathrm{AD}$ patients compared with untreated patients [236]. The above clinical trials included small sample sizes and should initiate future examinations evaluating the effect of different types of $\mathrm{AD}$ medications on $\mathrm{OS}$ markers in $\mathrm{AD}$ patients.

\section{Animal Studies}

\section{Oxidative Biomarkers}

$\mathrm{AD}$ can be modeled by several procedures in animal. Injection with scopolamine (i.p.), streptozotocin (intracerebroventricular (i.c.v.)), $\mathrm{A} \beta$ (i.c.v.), or apolipoprotein $\mathrm{E}(\mathrm{APOE})$ in transgenic models is used to study sporadic $\mathrm{AD}$, while amyloid precursor protein (APP) and presenilin 1 (PSEN1) and PSEN2 transgenic models are used to examine familial AD [237-240]. For detailed descriptions of AD animal models, see [241-246].

In both pharmacological and genetic models of $\mathrm{AD}$, disordered OS biomarkers are present in animal brains (Table 10). MDA, HNE, or TBARS were enhanced in all of those models in the cerebral cortex or/and hippocampus or/and the whole brain [237-241, 247-255]. Oxidative modification of proteins has also been demonstrated in the cortex and whole brain homogenate of transgenic AD mice $[253,255]$ and in the cerebral cortex and hippocampus of an $\mathrm{A} \beta_{1-42}$ mouse model [247]. In addition to OS due to oxygen, there is also proof of the presence of NS in whole brain lysates from the APP23 transgenic AD mouse model [251].

\section{Antioxidant Defense Biomarkers}

Antioxidant defense biomarkers have been found to be changed in AD models (see Table 10). Diminished levels of GSH in the cerebral cortex or hippocampus or in whole brain lysates have been demonstrated in pharmacologically induced AD animal models [237, 238, 240, 241, 247, 250, 254, 256].
Furthermore, the activities of enzymes connected with GSH metabolism, such as GPx and GR, and the enzymes involved in antioxidant defense (SOD and CAT) were reduced in the hippocampus and cerebral cortex in pharmacological and genetic models [237, 238, 241, 248, 249, 254-256]. It should be noted that some studies demonstrated no change in CAT and SOD activity in whole brain lysates in Wistar rats in the streptozotocin model [240], while enhanced SOD, GPx, and GR were observed in the mouse cerebral cortex and hippocampus following i.c.v. $A \beta_{1-42}$ injection [247]. It is also important to mention that in transgenic models, the changes depend on animal age. For example, APPswe/PS1dE9 mice at 2.5 months of age did not exhibit any significant changes in measures of OS and cognitive function, whereas 3.5-monthold mice showed diminished SOD and GPx activity and increased MDA and PC levels that were accompanied by spatial memory impairments [255].

\section{Pharmacotherapeutic Strategy to Reduce OS}

Several preclinical studies on AD have shown that many antioxidants can both diminish OS and improve cognitive impairments (Table 11). Among different compounds of special interest are vitamin $\mathrm{E}$, vitamin $\mathrm{C}$, and $\alpha$-lipoic acid. Vitamin $\mathrm{E}$ given 7 days before $A \beta_{1-42}$ decreased MDA and protein carbonyls in the mouse hippocampus and cortex [247]. Similarly, $\alpha$-lipoic acid enrichment decreased HNE levels in AbPP Tg2576 mouse brains but did not decrease 3-NT levels [251]. In AbPP Tg2576 mice that overexpress a mutant form of APP (beta amyloid ( $\beta \mathrm{A})$, an (A4) precursor protein) and show impaired learning, an R- $\alpha$-lipoic acid-enriched diet, administered for 10 months, decreased HNE levels in total brain homogenates and also attenuated HNE protein adducts that accumulated around amyloid deposits in the hippocampal and cortical region, but it had little effect on cognitive performance and brain $A \beta$ load. This latter study seems to suggest that a long-term antioxidant therapy that reduced oxidative modifications provided a limited benefit [251].

In contrast to the study that used $\alpha$-lipoic acid, vitamin $\mathrm{C}$, when administered to other transgenic lines, such as APP/PSEN1 mice, did not decrease enhanced MDA levels in the cortex or $A \beta$ plaque deposits in the cortex and 
Table 10 OS biomarkers and OS defense biomarkers in pharmacologically developed and in transgenic AD animal models

\begin{tabular}{|c|c|c|c|c|}
\hline Animal model (dosage) & Animal species & OS biomarkers & OS defense biomarkers & Reference \\
\hline $\mathrm{A} \beta_{1-42}$ (i.c.v. injection) & Mice & $\begin{array}{l}\uparrow \mathrm{MDA} \text { in cerebral CTX } \\
\text { and HIP }\end{array}$ & $\begin{array}{l}\downarrow \mathrm{SOD}, \downarrow \mathrm{GPx}, \downarrow \mathrm{GSH}, \uparrow \mathrm{GSSG} \text { in } \\
\text { cerebral CTX and HIP }\end{array}$ & [237] \\
\hline $\mathrm{A} \beta_{1-42}$ injection (i.c.v. injection) & Mice (Chinese Kun Ming) & $\begin{array}{l}\uparrow \text { MDA in cerebral CTX } \\
\text { and HIP }\end{array}$ & $\begin{array}{l}\downarrow \text { SOD }, \downarrow \text { GPx }, \downarrow \text { GSH in HIP and } \\
\quad \text { cerebral CTX }\end{array}$ & {$[241]$} \\
\hline $\mathrm{A} \beta_{1-42}$ (i.c.v. injection $400 \mathrm{pmol}$ ) & Mice (C57BL/6) & $\begin{array}{l}\uparrow \mathrm{MDA}, \uparrow \mathrm{PC} \text { in cerebral } \\
\mathrm{CTX} \text { and HIP }\end{array}$ & $\begin{array}{l}\uparrow \mathrm{Mn}-\mathrm{SOD}, \uparrow \mathrm{Zn}, \mathrm{Cu}-\mathrm{SOD}, \uparrow \mathrm{GPx} \\
\text { (only up to } 2 \text { days after } \mathrm{A} \beta_{1-42} \\
\text { injection), } \uparrow \mathrm{GR} \text { (only } 2 \mathrm{~h} \text { after } \\
\mathrm{A} \beta_{1-42} \text { injection) in cerebral CTX } \\
\text { and HIP }\end{array}$ & {$[247]$} \\
\hline $\begin{array}{l}\text { Scopolamine }(2 \mathrm{mg} / \mathrm{kg} \text { i.p. once } \\
\text { per day for } 2 \text { weeks })\end{array}$ & Mice (Kun Ming) & $\uparrow \mathrm{MDA}$ in HIP & $\downarrow \mathrm{SOD}, \downarrow \mathrm{GSH}$ in HIP & [238] \\
\hline $\begin{array}{l}\text { Scopolamine (1 mg/kg, i.p. single } \\
\text { injection) }\end{array}$ & Mice (Swiss) & $\uparrow \mathrm{MDA}$ in CTX and HIP & $\begin{array}{l}\downarrow \mathrm{SOD}, \downarrow \mathrm{GPx}, \downarrow \mathrm{GSH}-\mathrm{Rx} \text { in CTX } \\
\text { and HIP }\end{array}$ & {$[248]$} \\
\hline $\begin{array}{l}\text { Scopolamine }(1.4 \mathrm{mg} / \mathrm{kg} \text {, i.p. } \\
\text { single injection) }\end{array}$ & Mice (Swiss) & $\uparrow \mathrm{MDA}$ in whole brain lysate & $\downarrow$ CAT in whole brain lysate & [249] \\
\hline $\begin{array}{l}\text { AF64A, a cholinotoxin }(2 \mathrm{nmol} / \\
2 \mu \mathrm{l} \text {, bilaterally single i.c.v. } \\
\text { injection })\end{array}$ & Rat (Wistar) & $\uparrow \mathrm{MDA}$ in HIP & nd & [239] \\
\hline $\begin{array}{l}\text { Streptozotocin }(3 \mathrm{mg} / \mathrm{kg} \\
\text { bilaterally i.c.v. injection on } \\
\text { days } 1 \text { and } 3)\end{array}$ & Rat (Wistar) & $\uparrow \mathrm{MDA}$ in whole brain lysate & $\begin{array}{l}\downarrow \mathrm{GSH}, \varnothing \mathrm{CAT}, \varnothing \mathrm{SOD} \text { in whole } \\
\quad \text { brain lysate }\end{array}$ & {$[240]$} \\
\hline $\begin{array}{l}\text { Streptozotocin }(2.57 \mathrm{mg} / \mathrm{kg} \\
\quad \text { bilaterally single i.c.v. injection })\end{array}$ & Mice (Swiss albino) & $\uparrow$ TBARS in HIP & $\downarrow \mathrm{GSH}, \downarrow \mathrm{GPx}, \downarrow \mathrm{GR}$ in HIP & {$[250]$} \\
\hline $\begin{array}{l}\text { Streptozotocin }(3.0 \mathrm{mg} / \mathrm{kg} \text { i.c.v. } \\
\text { single injection, } 5 \mu \mathrm{l} / \text { injection } \\
\text { per site) }\end{array}$ & Rat (Wistar) & $\begin{array}{l}\uparrow \mathrm{HNE}, \uparrow \mathrm{MDA}, \uparrow \mathrm{TBARS}, \\
\uparrow \mathrm{PC} \text { in HIP }\end{array}$ & $\begin{array}{l}\downarrow \mathrm{GSH}, \downarrow \mathrm{GPx}, \downarrow \mathrm{GR}, \downarrow \mathrm{CAT}, \downarrow \mathrm{SOD} \\
\quad \text { in HIP }\end{array}$ & [256] \\
\hline AbPP Tg2576 transgenic mice & & $\uparrow \mathrm{HNE}, \uparrow 3-\mathrm{NT}$ in whole brain & nd & {$[251]$} \\
\hline APP/PSEN1 transgenic mice & & $\uparrow \mathrm{MDA}$ in HIP & nd & {$[252]$} \\
\hline APP23 transgenic mice & & $\uparrow \mathrm{PC}$ in CTX & nd & [253] \\
\hline Heterozygote APP transgenic mice & & $\begin{array}{l}\uparrow \text { TBARS in the brain } \\
\text { homogenate }\end{array}$ & $\downarrow \mathrm{GSH}, \downarrow \mathrm{SOD}$ in the brain homogenate & {$[254]$} \\
\hline APPswe/PS1dE9 transgenic mice & & $\begin{array}{l}\uparrow \mathrm{MDA}, \uparrow P C \text { in the brain } \\
\text { homogenate }\end{array}$ & $\downarrow \mathrm{SOD}, \downarrow$ GPx in the brain homogenate & {$[255]$} \\
\hline
\end{tabular}

$\uparrow$ increase, $\downarrow$ decrease, $n d$ not determined, 3-NT3-nitrotyrosine, CTX cortex, GSH glutathione, CAT catalase, GPx glutathione peroxidase, GR glutathione reductase, GSSG oxidized glutathione, HIP hippocampus, HNE 4-hydroxynonenal, i.c.v. intracerebroventricular, i.p. intraperitoneal, $M D A$ malonyldialdehyde, $M n$-SOD manganese superoxide dismutase (located in mitochondria), $P C$ protein carbonyl, $S O D$ superoxide dismutase, TBARS thiobarbituric acid reactive substances, $\mathrm{Zn}, \mathrm{Cu}$-SOD copper/zinc superoxide dismutase (located in cytoplasm)

hippocampal regions in either middle-aged or aged animals [252], although the drug administration improved memory, according to tests that suggested that cognitive rescue was achieved, to some degree, even in animals that suffered from severe neuropathology. The lack of effect of vitamin $\mathrm{C}$ on $\mathrm{A} \beta$ plaque deposits seems to result from the late introduction of medication in this test because $A \beta$ plaques, considered an end point in the disease process, are detectable in these mice at $4-5$ months, which was before the beginning of the test [252]. It is also possible that ascorbate had an effect on soluble A $\beta$ [252]. Reduced vitamin C supplementation has been shown to cause enhanced OS in the form of MDA in APP/PSEN1 mice, which are not able to endogenously synthesize vitamin C [257]. This latter observation led to the conclusion that vitamin $\mathrm{C}$ may not be an anti-OS medication per se, but its deficiency in $\mathrm{AD}$ patients may lead to oxidative damage. Interestingly, another study showed that the long-lasting incretin hormone analogue D-Ala ${ }^{2}$ GIP (glucose-dependent insulinotropic polypeptide) was able to decrease OS biomarkers (i.e., 8-OHG) and amyloid plaque load in 12- and 19-month-old APPswe/PS1 mice [258]. Many natural compounds that possess antioxidant properties have been tested in animal models as AD treatments. Imperatorin and hesperidin diminished brain damage due to OS, and most of them enhanced the power of oxidative defenses [238-241, 259]. Moreover, meloxicam (an antiinflammatory drug) and selegiline, given alone or in combination, inhibited lipid peroxidation, prevented a decrease in CAT activity, and showed memory-enhancing capacity in a scopolamine AD model [249]. Another compound, $S$ allyl cysteine, which is a sulfur-containing amino acid that was reported to have antioxidant and neurotrophic activity, prevented cognitive and neurobehavioral impairments, 
Table 11 Studies with substances/drugs with antioxidant properties in different AD animal models and their influence on oxidative damage and antioxidative defense and biomarkers

\begin{tabular}{|c|c|c|c|c|}
\hline Model & $\begin{array}{l}\text { Oxidative damage and } \\
\text { defense biomarkers }\end{array}$ & Drug and route of administration & $\begin{array}{l}\text { Changes in oxidative } \\
\text { defense biomarkers }\end{array}$ & Reference \\
\hline $\begin{array}{l}\text { A } \beta_{1-42} \text { i.c.v. to mice } \\
\text { (Chinese Kun Ming) }\end{array}$ & $\begin{array}{l}\uparrow \mathrm{MDA}, \downarrow \mathrm{SOD}, \downarrow \mathrm{GPx}, \\
\downarrow \mathrm{GSH} \text { in HIP and } \\
\text { cerebral CTX }\end{array}$ & $\begin{array}{l}\text { Schisantherin A } 0.1 \mathrm{mg} / \mathrm{kg} \text { for } 5 \text { days } \\
\text { i.c.v., injection started after } 3 \text { days } \\
\text { from } \mathrm{A} \beta_{1-42} \text { injection }\end{array}$ & $\begin{array}{l}\downarrow \text { MDA in cerebral CTX, } \\
\uparrow \text { SOD, } \uparrow \mathrm{GPX}, \uparrow \mathrm{GSH} \\
\quad \text { in HIP and cerebral CTX }\end{array}$ & [241] \\
\hline $\begin{array}{l}\mathrm{A} \beta_{1-42} \text { i.c.v. to mice } \\
\quad(\mathrm{C} 57 \mathrm{BL} / 6)\end{array}$ & $\begin{array}{l}\uparrow \mathrm{MDA}, \uparrow \mathrm{PC}, \uparrow \mathrm{Mn}-\mathrm{SOD}, \\
\uparrow \mathrm{Zn}, \mathrm{Cu}-\mathrm{SOD}, \uparrow \mathrm{GPx}, \\
\uparrow \mathrm{GR} \text { in cerebral CTX } \\
\text { and HIP }\end{array}$ & $\begin{array}{l}\text { Vitamin } \mathrm{E} 150 \mathrm{mg} / \mathrm{kg}, \text { p.o. for } 27 \text { days, } \\
\text { administration began } 7 \text { days before } \\
\mathrm{A} \beta_{1-42} \text { i.c.v. }\end{array}$ & $\begin{array}{l}\downarrow \mathrm{MDA}, \downarrow \mathrm{PC}, \downarrow \mathrm{Mn}-\mathrm{SOD}, \\
\downarrow \text { Zn, Cu-SOD, } \uparrow \mathrm{GPx}, \\
\varnothing \text { GR in cerebral CTX } \\
\text { and HIP }\end{array}$ & [247] \\
\hline $\begin{array}{l}\text { AF64A (a cholinotoxin) } \\
2 \mathrm{nmol} / 2 \mu \mathrm{l} \text {, bilaterally } \\
\text { i.c.v. to rats (Wistar) }\end{array}$ & $\uparrow \mathrm{MDA}$ in HIP & $\begin{array}{c}\text { Piperine } 5 \text { or } 10 \mathrm{mg} / \mathrm{kg} \text { p.o. } 2 \text { weeks } \\
\text { before and } 1 \text { week after AF64A }\end{array}$ & $\downarrow \mathrm{MDA}$ in HIP & [239] \\
\hline $\begin{array}{l}\text { Streptozotocin } 2.57 \mathrm{mg} / \\
\mathrm{kg} \text { i.c.v. to mice } \\
\text { (Swiss albino) }\end{array}$ & $\begin{array}{l}\uparrow \text { TBARS, } \downarrow \text { GSH, } \downarrow \text { GPx, } \\
\downarrow \text { GR in HIP }\end{array}$ & $\begin{array}{l}\text { S-allyl cysteine } 30 \mathrm{mg} / \mathrm{kg} \text { i.p. for } 15 \text { days } \\
\text { pre-treatment before streptozocin }\end{array}$ & $\begin{array}{l}\downarrow \text { TBARS, } \uparrow \text { GSH, } \uparrow \text { GPx, } \\
\uparrow \text { GR in HIP }\end{array}$ & {$[250]$} \\
\hline $\begin{array}{l}\text { Scopolamine } 1 \mathrm{mg} / \mathrm{kg} \text { i.p } \\
\text { single injection to mice } \\
\text { (Swiss) } 20 \text { min before } \\
\text { pretest (memory acquisition) } \\
\text { or } 15 \text { min after pretest } \\
\text { (memory consolidation) }\end{array}$ & $\begin{array}{c}\uparrow \mathrm{MDA}, \downarrow \mathrm{SOD}, \downarrow \mathrm{GPx}, \downarrow \\
\text { GR in CTX and HIP }\end{array}$ & $\begin{array}{l}\text { Imperatorin } 1,5 \text {, or } 10 \mathrm{mg} / \mathrm{kg} \text { i.p. } 2 \times / \text { day } \\
\text { for } 7 \text { days (on } 7 \text { th day (pretest): } 10 \mathrm{~min} \\
\text { before scopolamine injection or } 15 \mathrm{~min} \\
\text { after scopolamine injection }\end{array}$ & $\begin{array}{l}\downarrow \text { MDA, } \uparrow \text { SOD in CTX and } \\
\text { HIP, } \uparrow \text { GPX in CTX and } \\
\text { HIP, } \uparrow \text { GR in CTX }\end{array}$ & {$[248]$} \\
\hline Mice (AbPP Tg2576) & $\begin{array}{l}\uparrow \mathrm{HNE}, \uparrow 3-\mathrm{NT} \text { in brain } \\
\text { homogenates }\end{array}$ & $\begin{array}{l}\alpha \text {-lipoic acid } 30 \mathrm{mg} / \mathrm{kg} / \text { day enriched diet } \\
\text { for } 10 \text { months }\end{array}$ & $\begin{array}{l}\downarrow \text { HNE, Ø 3-NT in brain } \\
\quad \text { homogenates }\end{array}$ & {$[251]$} \\
\hline Mice (APP/PSEN1 transgenic) & $\uparrow M D A$ in HIP & Vitamin C $125 \mathrm{mg} / \mathrm{kg}$ i.p. for 12 days & $\varnothing \mathrm{MDA}$ in HIP & {$[252]$} \\
\hline Mice (Gulo-/- APP/PSEN1) & $\begin{array}{l}\text { MDA level in CTX on } \\
\text { vitamin C content } \\
\text { standard diet }(0.33 \mathrm{~g} / \mathrm{L} \\
\text { of drinking water) not } \\
\text { changed }\end{array}$ & $\begin{array}{l}\text { Vitamin C- low diet content } 0.099 \mathrm{~g} / \mathrm{L} \\
\text { of drinking water }\end{array}$ & $\uparrow \mathrm{MDA}$ in CTX & {$[257]$} \\
\hline Mice (APPswe/PS1) & nd & Melatonin $5 \mathrm{mg} / \mathrm{kg}$ p.o. for 5.5 months & $\downarrow \mathrm{MDA}, \downarrow \mathrm{PC}$ in HIP & {$[260]$} \\
\hline Mice (heterozygote APP) & $\begin{array}{l}\uparrow \mathrm{TBARS}, \downarrow \mathrm{GSH}, \downarrow \mathrm{SOD} \\
\text { in the brain homogenate }\end{array}$ & $\begin{array}{l}\text { Melatonin } 10 \mathrm{mg} / \mathrm{kg} / \text { day for } 4 \text { months } \\
\text { intargastrically }\end{array}$ & $\begin{array}{l}\downarrow \text { TBARS }, \uparrow \mathrm{GSH}, \uparrow \mathrm{SOD} \text { in } \\
\text { the brain homogenate }\end{array}$ & {$[254]$} \\
\hline Mice (APPswe/PS1) & nd & $\begin{array}{l}\text { Long-lasting incretin hormone analogue } \\
\text { D-Ala }{ }^{2} \mathrm{GIP} \\
35 \text { days at } 25 \mathrm{nmol} / \mathrm{kg} \text { i.p. once daily }\end{array}$ & $\begin{array}{l}\downarrow 8-\mathrm{OHG} \text { in CA1 HIP region } \\
\text { (in } 12 \text { and } 19 \text { months old } \\
\text { mice) }\end{array}$ & {$[258]$} \\
\hline Mice (APPswe/PS1) & $\begin{array}{l}\uparrow \mathrm{H}_{2} \mathrm{O}_{2}, \uparrow \mathrm{MDA}, \downarrow \mathrm{GSH}, \downarrow \\
\text { TAC in whole brain } \\
\text { lysate }\end{array}$ & $\begin{array}{l}\text { Hesperidin } 100 \mathrm{mg} / \mathrm{kg} \text { per day for } \\
16 \text { weeks in chow }\end{array}$ & $\begin{array}{l}\downarrow \mathrm{H}_{2} \mathrm{O}_{2}, \downarrow \mathrm{MDA}, \uparrow \mathrm{GSH}, \uparrow \mathrm{TAC} \\
\quad \text { in whole brain lysate }\end{array}$ & [259] \\
\hline
\end{tabular}

$\uparrow$ increase, $\downarrow$ decrease, $\varnothing$ no changes, 3-NT 3-nitrotyrosine, CAT catalase, CTX cortex, D- $A l a^{2}$ GIP glucose-dependent insulinotropic polypeptide, GPX glutathione peroxidase, GR glutathione reductase, GSH glutathione, GSSG oxidized glutathione, HIP hippocampus, HNE 4-hydroxynonenal, i.c.v. intracerebroventricular, i.p. intraperitoneal, $M D A$ malonyldialdehyde, $M n$-SOD manganese superoxide dismutase (located in mitochondria), $P C$ protein carbonyl, $S O D$ superoxide dismutase, TAC total antioxidant capacity, TBARS thiobarbituric acid reactive substances, $Z n, C u$-SOD copper/zinc superoxide dismutase (located in cytoplasm)

prevented ROS damage in the hippocampus, and augmented endogenous antioxidant enzymes in a streptozocin AD model [250]. Similar results were obtained when melatonin was given chronically to a genetic AD mouse model, as the drug alleviated OS and enhanced GSH levels [254, 260]. Moreover, results from Feng et al. [254] showed that OS is an early event in $\mathrm{AD}$ pathogenesis and that antioxidant therapies may be beneficial if given at this stage of the disease [254].

As shown above, results from animal AD models that have used various pharmacological compounds to reduce $\mathrm{OS}$ and to alleviate memory deficits in $\mathrm{AD}$ are promising but do not yet parallel the results obtained in clinical trials.

\section{Anti-Alzheimer's Disease Drugs that Modulate Oxidative Balance}

Medications used to treat Alzheimer's disease have been shown to have antioxidant properties that depend on the dose and AD model (Table 12). For example, tacrine, the first anticholinesterase inhibitor approved by the Food and Drug Administration (FDA), was shown to suppress OS in an animal AD model [261]. In fact, tacrine $(50-800 \mu \mathrm{g} / \mathrm{kg}$ i.m.) increased the FRAP value, which serves as a measure of "antioxidant power" [262], without elevating any marker of OS-associated damage in brain tissue. The effect of tacrine may therefore be considered to be positive when this drug is 
Table 12 Trials with anti-Alzheimer drugs in different AD animal models and their influence on oxidative damage and anti-oxidative defense biomarkers

\begin{tabular}{|c|c|c|c|c|}
\hline Model & Oxidative defense biomarkers & Drug and route of administration & $\begin{array}{l}\text { Changes in oxidative } \\
\text { defense biomarkers }\end{array}$ & Reference \\
\hline $\begin{array}{l}\text { Scopolamine } 2 \mathrm{mg} / \mathrm{kg} \text { i.p. once } \\
\text { per day for } 2 \text { weeks to mice } \\
\text { (Kun Ming) }\end{array}$ & $\uparrow \mathrm{MDA}, \downarrow \mathrm{SOD}, \downarrow \mathrm{GSH}$ in HIP & $\begin{array}{r}\text { Donepezil ( } 3 \mathrm{mg} / \mathrm{kg} / \text { day p.o. } \\
\text { once per day for } 2 \text { weeks })\end{array}$ & $\begin{array}{l}\downarrow \mathrm{MDA}, \downarrow \mathrm{SOD}, \uparrow \mathrm{GSH} \text { in } \\
\quad \mathrm{HIP}\end{array}$ & [238] \\
\hline $\begin{array}{l}\mathrm{A} \beta_{1-42} 3 \mu \mathrm{l} \text { of } 1 \mathrm{mg} / \mathrm{ml} \text { solution. } \\
\text { i.c.v. to mice (Chinese Kun } \\
\text { Ming) }\end{array}$ & $\begin{array}{l}\uparrow \mathrm{MDA}, \downarrow \mathrm{SOD}, \downarrow \mathrm{GPx}, \downarrow \mathrm{GSH} \\
\text { in HIP and cerebral CTX }\end{array}$ & $\begin{array}{l}\text { Donepezil }(0.01 \mathrm{mg} / \mathrm{kg} / \text { day i.c.v. } \\
\quad \text { for } 14 \text { days })\end{array}$ & $\begin{array}{l}\downarrow \mathrm{MDA}, \uparrow \mathrm{GSH}, \uparrow \mathrm{GPx}, \varnothing \\
\text { SOD in HIP and } \\
\text { cerebral CTX }\end{array}$ & {$[241]$} \\
\hline $\begin{array}{l}\text { Mice APPswe/PS1 (transgenic } \\
\text { model) }\end{array}$ & $\uparrow \mathrm{H}_{2} \mathrm{O}_{2}, \uparrow \mathrm{MDA}, \downarrow \mathrm{GSH}, \downarrow \mathrm{TAC}$ & $\begin{array}{l}\text { Donepezil }(2.5 \mathrm{mg} / \mathrm{kg} / \text { day for } \\
16 \text { weeks })\end{array}$ & $\begin{array}{l}\downarrow \mathrm{H}_{2} \mathrm{O}_{2}, \downarrow \mathrm{MDA}, \downarrow \mathrm{GSH}, \varnothing \\
\text { TAC }\end{array}$ & [259] \\
\hline $\begin{array}{l}\text { Scopolamine } 1.4 \mathrm{mg} / \mathrm{kg} \text { i.p. once } \\
\text { a day for } 9 \text { days to mice } \\
\text { (Swiss) }\end{array}$ & $\begin{array}{l}\uparrow \mathrm{MDA}, \downarrow \mathrm{CAT} \text { in whole brain } \\
\text { lysate }\end{array}$ & $\begin{array}{l}\text { Donepezil ( } 5 \mathrm{mg} / \mathrm{kg} \text { p.o. once a } \\
\text { day for } 9 \text { days before } \\
\text { scopolamine administration) }\end{array}$ & $\begin{array}{l}\downarrow \mathrm{MDA}, \uparrow \mathrm{CAT} \text { in whole } \\
\text { brain lysate }\end{array}$ & [249] \\
\hline $\begin{array}{l}\text { Streptozotocin } 0.5 \mathrm{mg} / \mathrm{kg} \text { i.c. on } \\
1 \mathrm{st} \text { and } 3 \mathrm{rd} \text { day to mice (Swiss } \\
\text { albino) }\end{array}$ & $\begin{array}{l}\uparrow \mathrm{MDA}, \downarrow \mathrm{GSH} \text { in whole brain } \\
\text { lysate }\end{array}$ & $\begin{array}{l}\text { Tacrine ( } 5 \mathrm{mg} / \mathrm{kg} / \text { day p.o.) or } \\
\text { donepezil (5 mg/kg/day p.o.) } \\
\text { for } 7 \text { days }\end{array}$ & $\begin{array}{l}\downarrow \text { MDA, } \uparrow \text { GSH (not } \\
\text { significant) in whole } \\
\text { brain lysate }\end{array}$ & {$[261]$} \\
\hline $\begin{array}{l}\text { Colchicine } 5 \mu \mathrm{g} / 5 \mu \mathrm{l} \text { i.c.v. injec- } \\
\text { tion to rats (Wistar) }\end{array}$ & $\uparrow \mathrm{MDA}, \downarrow \mathrm{GSH}$ in brain & $\begin{array}{l}\text { Rivastigmine }(2.5 \mathrm{mg} / \mathrm{kg} \text { p.o. for } \\
28 \text { days started } 7 \text { days before } \\
\text { colchicine injection) }\end{array}$ & $\varnothing \mathrm{MDA}, \varnothing \mathrm{GSH}$ in brain & [264] \\
\hline $\begin{array}{l}\text { Kainic acid (KA) } 0.4 \mu \mathrm{g} / 2 \mu \mathrm{l} \\
\text { single unilateral } \\
\text { intrahippocampal injection to } \\
\text { rats (Wistar) }\end{array}$ & $\begin{array}{l}\uparrow \mathrm{MDA}, \uparrow \text { nitrate, } \downarrow \text { GSH }, \uparrow \\
\text { GSSG in HIP }\end{array}$ & $\begin{array}{l}\text { Galantamine }(2.5 \mathrm{mg} \text { or } 5 \mathrm{mg} / \mathrm{kg} \\
\text { for } 14 \text { days starting from the } \\
\text { day of KA injection })\end{array}$ & $\begin{array}{l}\uparrow \mathrm{MDA}, \uparrow \text { nitrate, } \downarrow \text { GSH, } \uparrow \\
\text { GSSG in HIP }\end{array}$ & [266] \\
\hline $\begin{array}{l}\mathrm{A} \beta_{25-35} \text { i.c.v. injection once a } \\
\text { day for } 3 \text { consecutive days to } \\
\text { rats (Wistar) }\end{array}$ & $\uparrow$ iNOS in HIP & $\begin{array}{l}\text { Memantine }(5 \mathrm{mg} / \mathrm{kg} / \text { day i.p. for } \\
8 \text { days, } 3 \text { times after } \mathrm{A} \beta_{25-35} \\
\text { injection and for } 5 \text { following } \\
\text { post- } \mathrm{A} \beta_{25-35} \text { days) }\end{array}$ & $\downarrow$ i NOS in HIP & [268] \\
\hline $\begin{array}{l}\text { Age-induced memory } \\
\text { impairment in rats (Wistar) } \\
\text { (24 months old) }\end{array}$ & $\uparrow \mathrm{PC}$ in HIP and CTX & $\begin{array}{l}\text { Memantine }(20 \mathrm{mg} / \mathrm{kg} \text { i.p. for } \\
21 \text { days })\end{array}$ & $\downarrow \mathrm{PC}$ in HIP and CTX & {$[267]$} \\
\hline $\begin{array}{l}\text { Streptozocin } 10 \mu \mathrm{l} \text { injection of } \\
3 \mathrm{mg} / \mathrm{kg} \text { bilaterally on } 1 \mathrm{st} \text { and } \\
3 \mathrm{rd} \text { day to rats (Sprague- } \\
\text { Dawley) }\end{array}$ & $\begin{array}{l}\uparrow \mathrm{ROS}, \uparrow \text { nitrate in CTX and } \\
\text { HIP }\end{array}$ & $\begin{array}{l}\text { Memantine }(10 \mathrm{mg} / \mathrm{kg} \text { p.o. for } \\
13 \text { days starting from STZ } \\
\text { injection) }\end{array}$ & $\begin{array}{l}\downarrow \text { ROS, } \downarrow \text { nitrate in CTX } \\
\text { and HIP }\end{array}$ & [269] \\
\hline $\begin{array}{l}\text { Kainic acid } 200 \mathrm{ng} / 10 \mu \mathrm{l} \text { bilater- } \\
\text { ally i.c.v. to rats (Sprague- } \\
\text { Dawley) }\end{array}$ & $\begin{array}{l}\uparrow \mathrm{ROS}, \uparrow \mathrm{MDA}, \text { in STR, CTX, } \\
\text { cerebellum, HIP, } \uparrow \text { nitrite in } \\
\text { CTX, HIP }\end{array}$ & $\begin{array}{l}\text { Memantine }(10 \mathrm{mg} / \mathrm{kg} \text { p.o. for } \\
13 \text { days starting from the day } \\
\text { of OKA injection) }\end{array}$ & $\begin{array}{l}\downarrow \text { ROS, } \downarrow \text { MDA in STR, } \\
\text { CTX, cerebellum, HIP, } \\
\downarrow \text { nitrite in CTX, HIP }\end{array}$ & {$[270]$} \\
\hline
\end{tabular}

$\uparrow$ increase, $\downarrow$ decrease, $\varnothing$ no changes, $n d$ not determined, 3-NT 3-nitrotyrosine, $A l C l_{3}$ aluminum chloride, $C A T$ catalase, $C T X$ cortex, $G P x$ glutathione peroxidase, GR glutathione reductase, GSH glutathione, GSSG oxidized glutathione, HIP hippocampus, HNE 4-hydroxynonenal, i.c. intracerebral, i.c.v. intracerebroventricular, i.p. intraperitoneal, $K A$ kainic acid, $M D A$ malonyldialdehyde, $P C$ protein carbonyl, $S O D$ superoxide dismutase, $S T R$ striatum, $T A C$ total antioxidant capacity, TBARS thiobarbituric acid reactive substances

used in doses that stimulate the antioxidant system without inducing oxidative damage in brain tissue [263].

Donepezil is another cholinesterase inhibitor used in $\mathrm{AD}$ patients that, when given in doses as low as $3 \mathrm{mg} / \mathrm{kg}$ [259], $5 \mathrm{mg} / \mathrm{kg}$ [238, 249], or even $0.01 \mathrm{mg} / \mathrm{kg}$ [241] in a mouse AD model, both increased antioxidant power (CAT, SOD, GSH, or GPx, depending on the dose; see Table 12) and diminished lipid peroxidation [238, 241, 249]. However, donepezil, when given in a similar dose of $2.5 \mathrm{mg} / \mathrm{kg}$, failed to combat $\mathrm{OS}$ biomarkers and to stimulate antioxidant defenses in the APPswe/PS1 transgenic mouse AD model [259]. Those contradictory results come from studies using non-transgenic and transgenic animal AD models, which means that the multiple adaptations developed for use in these transgenic animals could be the reason for the observed difference in outcomes.
Another medication used in $\mathrm{AD}$ treatment is rivastigmine. This drug neither attenuated lipid peroxidation nor restored GSH depletion in the brains of rats in an AD model [264], although an older study indicated antioxidant properties for rivastigmine when $\mathrm{AD}$ was induced in rats by aluminum chloride administration [265]. Such differences in the effects of rivastigmine might be caused either by differences in the $\mathrm{AD}$ model used in the study (aluminum chlorate p.o. vs. colchicine i.c.v. models) or by differences in the rivastigmine dose regimen $(0.3 \mathrm{mg} / \mathrm{kg}$ for 3 months vs. $2.5 \mathrm{mg} / \mathrm{kg}$ p.o. for 28 days $)$. Based on the above scant reports, it is too soon to either confirm or exclude rivastigmine as an effective OS scavenger in $\mathrm{AD}$.

A single report showed the ability of another AChE inhibitor, galantamine, to reduce OS. In a cognitive impairment 
animal model, galantamine decreased lipid peroxidation, nitrate, and GSSG levels, enhanced SOD activity, and impaired GSH levels following kainic acid intrahippocampal injection, and it restored cognitive deficits as well [266].

Memantine has also been widely studied in preclinical AD models. For example, it was shown that memantine reduced oxidative damage to proteins in the cortex and hippocampus but not in the striatum, resulting in the reversal of concomitant age-induced recognition memory deficits in aged rats [267]. Other studies found that memantine diminished the level of inducible forms of NOS in an $\mathrm{A} \beta_{25-35} \mathrm{AD}$ model [268] and ROS and nitrate levels in the hippocampus and cortex in a streptozotocin AD model [269] and in a kainic acid-induced model of dementia [270]. However, memantine was shown to have neuroprotective properties not only in $\mathrm{AD}$ models but also in 3-nitropropionic acid [271], rotenone [272], and diisopropylphosphorofluoridate (DFP) toxicity models [273].

There is a wide range of evidence showing that several drugs used to treat $\mathrm{AD}$ have antioxidant properties, suggesting that at least part of their efficacy in animal models may come from that action.

\section{Summary and Conclusions}

In general, the presence of OS in the pathophysiology of many neurodegenerative disorders, including ALS, PD, and AD, is a well-recognized phenomenon. The results of many in vitro and in vivo preclinical and clinical studies have consistently demonstrated that OS is one of the crucial players in the degeneration that occurs in the nervous system. The imbalance between OS and antioxidant defense systems seems to be a universal condition in neurodegeneration. However, what can be surprising is that the results of many studies often provide different results when trying to determine the exact mechanisms that underlie OS and to determine which of the markers of OS could be clinically useful. What has been shown to be elevated in one study does not necessarily have to rise in another. In preclinical studies, these divergent results could be explained by the use of different models, different species, or different methodologies. As for the clinical setting, it must be stressed that the number of patients available for study is usually small because they are in different stages of their diseases, there are often coexisting comorbidities, and, last but not least, they often take many other medications with different pro- or antioxidant properties. The analysis of potential biomarkers under these conditions is extremely difficult. Therefore, assessing the real efficacy of potential antioxidant drugs is a challenge. However, there are some data, if even modest, that some of the existing drugs possess anti-oxidant properties and that they could slow down neurodegenerative processes and improve our understanding of the significance of OS in the pathobiology of these untreatable conditions.
The results of clinical and preclinical studies have demonstrated the presence of elevated levels of OS biomarkers as well as impairments to antioxidant defenses in the brain and peripheral tissues in $\mathrm{PD}, \mathrm{AD}$, and ALS. As the currently available therapies for these neurodegenerative diseases are not sufficiently effective for treating disease symptoms, novel substances are searched for. Among these, drugs with antioxidant activity, which are widely studied as a possible antineurodegenerative PD, AD, or ALS agents, can efficiently normalize biomarkers of the oxidant/antioxidant balance in animal models. Most such drugs have so far failed to slow down the progression of the disease or to prolong the lives of patients. Some exceptions within these antineurodegenerative drugs exist, and they give hope and inspire further research.

Acknowledgments This work has been supported by the statutory funds of the Jagiellonian University (K/ZDS/004127) and by the grant from the National Science Centre no. UMO-2011/01/B/NZ4/00708.

Open Access This article is distributed under the terms of the Creative Commons Attribution 4.0 International License (http:// creativecommons.org/licenses/by/4.0/), which permits unrestricted use, distribution, and reproduction in any medium, provided you give appropriate credit to the original author(s) and the source, provide a link to the Creative Commons license, and indicate if changes were made.

\section{References}

1. Li J, O W, Li W, Jiang Z, Ghanbari HA (2013) Oxidative stress and neurodegenerative disorders. Int J Mol Sci 14:24438-24475

2. Falkowski PG, Godfrey LV (2008) Electrons, life and the evolution of earth's oxygen cycle. Philosophical Transactions of the Royal Society of London Ser B, Biol Sci 363:2705-2716

3. Paiva CN, Bozza MT (2014) Are reactive oxygen species always detrimental to pathogens? Antioxid Redox Signal 20:1000-1037

4. Popa-Wagner A, Mitran S, Sivanesan S, Chang E, Buga A (2013) ROS and brain diseases: the good, the bad, and the ugly. Oxidative Med Cell Longevity 2013

5. Metodiewa D, Ko $`$ ka C (2000) Reactive oxygen species and reactive nitrogen species: relevance to cyto(neuro)toxic events and neurologic disorders. An overview. Neurotox Res 1:197-233

6. Venditti P, Di Stefano L, Di Meo S (2013) Mitochondrial metabolism of reactive oxygen species. Mitochondrion 13:71-82

7. Li X, Fang P, Mai J, Choi ET, Wang H, Yang X (2013) Targeting mitochondrial reactive oxygen species as novel therapy for inflammatory diseases and cancers. J Hematol Oncol 6

8. Mailloux RJ, McBride SL, Harper M (2013) Unearthing the secrets of mitochondrial ROS and glutathione in bioenergetics. Trends Biochem Sci 38:592-602

9. Cordeiro RM (2014) Reactive oxygen species at phospholipid bilayers: distribution, mobility and permeation. Biochim Biophys Acta 1838:438-444

10. Blough NV, Zafiriou OC (1985) Reaction of superoxide with nitric oxide to form peroxonitrite in alkaline aqueous solution. Inorg Chem 24:3502-3504

11. Forstermann U, Sessa WC (2012) Nitric oxide synthases: regulation and function. Eur Heart J 33:829-837 
12. Bedard K, Krause K (2007) The NOX family of ROS-generating NADPH oxidases: physiology and pathophysiology. Physiol Rev $87: 245-313$

13. Fritz KS, Petersen DR (2013) An overview of the chemistry and biology of reactive aldehydes. Free Radic Biol Med 59:85-91

14. Albarracin SL, Stab B, Casas Z, Sutachan JJ, Samudio I, Gonzalez J, Gonzalo L, Capani F, Morales L, Barreto GE (2012) Effects of natural antioxidants in neurodegenerative disease. Nutr Neurosci 15:1-9

15. Pinchuk I, Shoval H, Dotan Y, Lichtenberg D (2012) Evaluation of antioxidants: scope, limitations and relevance of assays. Chem Phys Lipids 165:638-647

16. Miller E, bieta, Morel A, Saso L, Saluk J (2014) Isoprostanes and neuroprostanes as biomarkers of oxidative stress in neurodegenerative diseases. Oxidat Med Cell Longevity 2014

17. Ho E, Karimi Galougahi K, Liu C, Bhindi R, Figtree GA (2013) Biological markers of oxidative stress: applications to cardiovascular research and practice. Redox Biol 1:483-491

18. Zitka O, Krizkova S, Skalickova S, Kopel P, Babula P, Adam V, Kizek R (2013) Electrochemical study of DNA damaged by oxidation stress. Comb Chem High Throughput Screen 16:130-141

19. Li J, Liu D, Sun L, Lu Y, Zhang Z (2012) Advanced glycation end products and neurodegenerative diseases: mechanisms and perspective. J Neurol Sci 317:1-5

20. Yavuz BB, Yavuz B, Halil M, Cankurtaran M, Ulger Z, Cankurtaran ES, Aytemir K, Ariogul S (2008) Serum elevated gamma glutamyltransferase levels may be a marker for oxidative stress in Alzheimer's disease. Int Psychogeriatr 20:815-823

21. Kadiiska MB, Basu S, Brot N, Cooper C, Saari Csallany A, Davies MJ, George MM, Murray DM, Jackson Roberts L IIL, Shigenaga MK, Sohal RS, Stocker R, Van Thiel DH, Wiswedel I, Hatch GE, Mason RP (2013) Biomarkers of oxidative stress study V: ozone exposure of rats and its effect on lipids, proteins, and DNA in plasma and urine. Free Radic Biol Med 61:408-415

22. Gomez-Mejiba SE, Zhai Z, Della-Vedova MC, Muñoz MD, Chatterjee S, Towner RA, Hensley K, Floyd RA, Mason RP, Ramirez DC (2014) Immuno-spin trapping from biochemistry to medicine: advances, challenges, and pitfalls. focus on proteincentered radicals. Biochim Biophys Acta - Gen Subj 1840:722729

23. Cozzolino M, Carrì MT (2012) Mitochondrial dysfunction in ALS. Prog Neurobiol 97:54-66

24. Chen S, Sayana P, Zhang X, Le W (2013) Genetics of amyotrophic lateral sclerosis: an update. Molec Neurodegen 8

25. Weiduschat N, Mao X, Hupf J, Armstrong N, Kang G, Lange DJ, Mitsumoto H, Shungu DC (2014) Motor cortex glutathione deficit in ALS measured in vivo with the J-editing technique. Neurosci Lett 570:102-107

26. Parakh S, Spencer DM, Halloran MA, Soo KY, Atkin JD (2013) Redox regulation in amyotrophic lateral sclerosis. Oxidat Med Cell Longevity

27. Blokhuis AM, Groen EJN, Koppers M, Van Den Berg LH, Pasterkamp RJ (2013) Protein aggregation in amyotrophic lateral sclerosis. Acta Neuropathol 125:777-794

28. Schymick JC, Talbot K, Traynor BJ (2007) Genetics of sporadic amyotrophic lateral sclerosis. Hum Mol Genet 16:R233-R242

29. Corcia P, Blasco H, Camu W (2014) Genetics of amyotrophic lateral sclerosis. Presse Med 43:555-562

30. Mendez EF, Sattler R (2015) Biomarker development for C9orf72 repeat expansion in ALS. Brain Res 1607:26-35

31. Beckman G, Lundgren E, Tarnvik A (1973) Superoxide dismutase isozymes in different human tissues, their genetic control and intracellular localization. Hum Hered 23:338-345

32. Saccon RA, Bunton-Stasyshyn RKA, Fisher EMC, Fratta P (2013) Is SOD1 loss of function involved in amyotrophic lateral sclerosis? Brain 136:2342-2358
33. Pasinelli P, Belford ME, Lennon N, Bacskai BJ, Hyman BT, Trotti D, Brown RH Jr (2004) Amyotrophic lateral sclerosis-associated SOD1 mutant proteins bind and aggregate with $\mathrm{Bcl}-2$ in spinal cord mitochondria. Neuron 43:19-30

34. Rakhit R, Crow JP, Lepock JR, Kondejewski LH, Cashman NR, Chakrabartty A (2004) Monomeric Cu, Zn-superoxide dismutase is a common misfolding intermediate in the oxidation models of sporadic and familial amyotrophic lateral sclerosis. J Biol Chem 279:15499-15504

35. Ezzi SA, Urushitani M, Julien J (2007) Wild-type superoxide dismutase acquires binding and toxic properties of ALS-linked mutant forms through oxidation. J Neurochem 102:170-178

36. Ito H, Wate R, Zhang J, Ohnishi S, Kaneko S, Ito H, Nakano S, Kusaka H (2008) Treatment with edaravone, initiated at symptom onset, slows motor decline and decreases SOD1 deposition in ALS mice. Exp Neurol 213:448-455

37. Watanabe M, Dykes-Hoberg M, Cizewski Culotta V, Price DL, Wong PC, Rothstein JD (2001) Histological evidence of protein aggregation in mutant SOD1 transgenic mice and in amyotrophic lateral sclerosis neural tissues. Neurobiol Dis 8:933-941

38. Forsberg K, Jonsson PA, Andersen PM, Bergemalm D, Graffmo KS, Hultdin M, Jacobsson J, Rosquist R, Marklund SL, Brännström T (2010) Novel antibodies reveal inclusions containing non-native SOD1 in sporadic ALS patients. PLoS ONE 5

39. Tohgi H, Abe T, Yamizaki K, Murata T, Ishizaki E, Isobe C (1999) Remarkable increase in cerebrospinal fluid 3-nitrotyrosine in patients with sporadic amyotrophic lateral sclerosis. Ann Neurol 46: 129-131

40. Smith RG, Henry YK, Mattson MP, Appel SH (1998) Presence of 4-hydroxynonenal in cerebrospinal fluid of patients with sporadic amyotrophic lateral sclerosis. Ann Neurol 44:696-699

41. Bogdanov M, Brown RH Jr, Matson W, Smart R, Hayden D, O'Donnell H, Flint Beal M, Cudkowicz M (2000) Increased oxidative damage to DNA in ALS patients. Free Radic Biol Med 29: $652-658$

42. Ihara Y, Nobukuni K, Takata H, Hayabara T (2005) Oxidative stress and metal content in blood and cerebrospinal fluid of amyotrophic lateral sclerosis patients with and without a $\mathrm{Cu}, \mathrm{Zn}$ superoxide dismutase mutation. Neurol Res 27:105-108

43. Barber SC, Shaw PJ (2010) Oxidative stress in ALS: key role in motor neuron injury and therapeutic target. Free Radic Biol Med 48:629-641

44. Oteiza PI, Uchitel OD, Carrasquedo F, Dubrovski AL, Roma JC, Fraga CG (1997) Evaluation of antioxidants, protein, and lipid oxidation products in blood from sporadic amiotrophic lateral sclerosis patients. Neurochem Res 22:535-539

45. Babu GN, Kumar A, Chandra R, Puri SK, Singh RL, Kalita J, Misra UK (2008) Oxidant-antioxidant imbalance in the erythrocytes of sporadic amyotrophic lateral sclerosis patients correlates with the progression of disease. Neurochem Int 52:1284-1289

46. LoGerfo A, Chico L, Borgia L, et al. (2014) Lack of association between nuclear factor erythroid-derived 2-like 2 promoter gene polymorphisms and oxidative stress biomarkers in amyotrophic lateral sclerosis patients. Oxidat Med Cell Longevity, vol. 2014, Article ID 432626, 9 pages, 2014. doi:10.1155/2014/432626

47. Mitsumoto H, Santella R, Liu X, Bogdanov M, Zipprich J, Wu H, Mahata J, Kilty M, Bednarz K, Bell D, Gordon PH, Hornig M, Mehrazin M, Naini A, Flint Beal M, Factor-Litvak P (2008) Oxidative stress biomarkers in sporadic ALS. Amyotrophic Lat Scler 9:177-183

48. Ikawa M, Okazawa H, Tsujikawa T, Muramatsu T, Kishitani T, Kamisawa T, Matsunaga A, Yamamura O, Mori T, Hamano T, Kiyono Y, Nakamoto Y, Yoneda M (2014) Increased cerebral oxidative stress in amyotrophic lateral sclerosis: a 62CU-ATSM pet study. Neurology 82 
49. Tohgi H, Abe T, Yamazaki K, Murata T, Ishizaki E, Isobe C (1999) Increase in oxidized NO products and reduction in oxidized glutathione in cerebrospinal fluid from patients with sporadic form of amyotrophic lateral sclerosis. Neurosci Lett 260:204206

50. Boll M, Alcaraz-Zubeldia M, Montes S, Murillo-Bonilla L, Rios C (2003) Raised nitrate concentration and low SOD activity in the CSF of sporadic ALS patients. Neurochem Res 28:699-703

51. Nikolic-Kokic A, Stevic Z, Blagojevic D, Davidovic B, Jones DR, Spasic MB (2006) Alterations in anti-oxidative defence enzymes in erythrocytes from sporadic amyotrophic lateral sclerosis (SALS) and familial ALS patients. Clin Chem Lab Med 44:589593

52. Apostolski S, Marinkovic Z, Nikolic A, Blagojevic D, Spasic MB, Michael Michelson A (1998) Glutathione peroxidase in amyotrophic lateral sclerosis: the effects of selenium supplementation. $\mathrm{J}$ Environ Pathol Toxicol Oncol 17:325-329

53. Kokic AN, Stevic Z, Stojanovic S, Blagojevic DP, Jones DR, Pavlovic S, Niketic V, Apostolski S, Spasic MB (2005) Biotransformation of nitric oxide in the cerebrospinal fluid of amyotrophic lateral sclerosis patients. Redox Rep 10:265-270

54. Süssmuth SD, Brettschneider J, Ludolph AC, Tumani H (2008) Biochemical markers in CSF of ALS patients. Curr Med Chem 15: 1788-1801

55. Tanaka H, Shimazawa M, Takata M, Kaneko H, Tsuruma K, Ikeda T, Warita H, Aoki M, Yamada M, Takahashi H, Hozumi I, Minatsu H, Inuzuka T, Hara H (2013) ITIH4 and Gpx3 are potential biomarkers for amyotrophic lateral sclerosis. J Neurol 260:17821797

56. Kuzma M, Jamrozik Z, Baranczyk-Kuzma A (2006) Activity and expression of glutathione S-transferase pi in patients with amyotrophic lateral sclerosis. Clin Chim Acta 364:217-221

57. Cova E, Bongioanni P, Cereda C, Metelli MR, Salvaneschi L, Bernuzzi S, Guareschi S, Rossi B, Ceroni M (2010) Time course of oxidant markers and antioxidant defenses in subgroups of amyotrophic lateral sclerosis patients. Neurochem Int 56:687-693

58. De Bustos F, Jiménez-Jiménez FJ, Molina JA, Esteban J, Guerrero-Sola A, Zurdo M, Ortì-Pareja M, Tallón-Barranco A, Gómez-Escalonilla C, Ramírez-Ramos C, Arenas J, Enríquez De Salamanca R (1998) Cerebrospinal fluid levels of alphatocopherol in amyotrophic lateral sclerosis. J Neural Transm 105:703-708

59. Paraskevas GP, Kapaki E, Libitaki G, Zournas C, Segditsa I, Papageorgiou C (1997) Ascorbate in healthy subjects, amyotrophic lateral sclerosis and Alzheimer's disease. Acta Neurol Scand 96:88-90

60. Johnson WM, Wilson-Delfosse AL, Mieyal JJ (2012) Dysregulation of glutathione homeostasis in neurodegenerative diseases. Nutrients 4:1399-1440

61. Desnuelle C, Dib M, Garrel C, Favier A (2001) A double-blind, placeho-controlled randomized clinical trial of a-tocopherol (vita$\min \mathrm{E}$ ) in the treatment of amyotrophic lateral sclerosis. Amyotrop Lateral Sclerosis Motor Neuron Disord 2:9-18

62. Graf M, Ecker D, Horowski R, Kramer B, Riederer P, Gerlach M, Hager C, Ludolph AC (2005) High dose vitamin E therapy in amyotrophic lateral sclerosis as add-on therapy to riluzole: results of a placebo-controlled double-blind study. J Neural Transm 112: 649-660

63. Veldink JH, Kalmijn S, Groeneveld G, Wunderink W, Koster A, De Vries JHM, Van Der Luyt J, Wokke JHJ, Van Den Berg LH (2007) Intake of polyunsaturated fatty acids and vitamin E reduces the risk of developing amyotrophic lateral sclerosis. J Neurol Neurosurg Psychiatry 78:367-371

64. Yoshino H, Kimura A (2006) Investigation of the therapeutic effects of edaravone, a free radical scavenger, on amyotrophic lateral sclerosis (phase II study). Amyotrop Later Sclerosis: Off Public World Fed Neurol Res Group Motor Neuron Dis 7:241-245

65. https://clinicaltrials.gov/show/NCT01492686. Accessed 15 May 2015

66. Kaufmann P, Thompson JLP, Levy G, Buchsbaum R, Shefner J, Krivickas LS, Katz J, Rollins Y, Barohn RJ, Jackson CE, Tiryaki E, Lomen-Hoerth C, Armon C, Tandan R, Rudnicki SA, Rezania K, Sufit R, Pestronk A, Novella SP, Heiman-Patterson T, Kasarskis EJ, Pioro EP, Montes J, Arbing R, Vecchio D, Barsdorf A, Mitsumoto H, Levin B (2009) Phase II trial of CoQ10 for ALS finds insufficient evidence to justify phase III. Ann Neurol 66:235-244

67. Groeneveld GJ, Veldink JH, Van der Tweel I, Kalmijn S, Beijer C, De Visser M, Wokke JHJ, Franssen H, Van den Berg LH (2003) A randomized sequential trial of creatine in amyotrophic lateral sclerosis. Ann Neurol 53:437-445

68. Louwerse ES, Weverling GJ, Bossuyt PMM, Meyjes FEP, De Jong JMBV (1995) Randomized, double-blind, controlled trial of acetylcysteine in amyotrophic lateral sclerosis. Arch Neurol 52:559-564

69. Lange DJ, Murphy PL, Diamond B, Appel V, Lai EC, Younger DS, Appel SH (1998) Selegiline is ineffective in a collaborative double-blind, placebo-controlled trial for treatment of amyotrophic lateral sclerosis. Arch Neurol 55:93-96

70. Weishaupt JH, Bartels C, Pölking E, Dietrich J, Rohde G, Poeggeler B, Mertens N, Sperling S, Bohn M, Hüther G, Schneider A, Bach A, Sirén A, Hardeland R, Bähr M, Nave K, Ehrenreich H (2006) Reduced oxidative damage in ALS by highdose enteral melatonin treatment. J Pineal Res 41:313-323

71. Zoccolella S., Santamato, A. Lamberti, P. (2009) Current and emerging treatments for amyotrophic lateral sclerosis. Neuropsychiat Dis Treatment Vol 5, Issue 1, 2009, Pages 577595 5:577-595

72. Turner BJ, Talbot K (2008) Transgenics, toxicity and therapeutics in rodent models of mutant SOD1-mediated familial ALS. Prog Neurobiol 85:94-134

73. McGoldrick P, Joyce PI, Fisher EMC, Greensmith L (2013) Rodent models of amyotrophic lateral sclerosis. Biochim Biophys Acta (BBA) - Mol Basis Dis 1832:1421-1436

74. Bogdanov MB, Ramos LE, Xu Z, Beal MF (1998) Elevated 'hydroxyl radical' generation in vivo in an animal model of amyotrophic lateral sclerosis. J Neurochem 71:1321-1324

75. Liu D, Wen J, Liu J, Li L (1999) The roles of free radicals in amyotrophic lateral sclerosis: reactive oxygen species and elevated oxidation of protein, DNA, and membrane phospholipids. FASEB J 13:2318-2328

76. Towner RA, Smith N, Saunders D, Lupu F, Silasi-Mansat R, West M, Ramirez DC, Gomez-Mejiba SE, Bonini MG, Mason RP, Ehrenshaft M, Hensley K (2013) In vivo detection of free radicals using molecular MRI and immuno-spin trapping in a mouse model for amyotrophic lateral sclerosis. Free Radic Biol Med 63:351360

77. Poon HF, Hensley K, Thongboonkerd V, Merchant ML, Lynn BC, Pierce WM, Klein JB, Calabrese V, Butterfield DA (2005) Redox proteomics analysis of oxidatively modified proteins in G93ASOD1 transgenic mice - a model of familial amyotrophic lateral sclerosis. Free Radic Biol Med 39:453-462

78. Liu D, Bao F, Wen J, Liu J (2007) Mutation of superoxide dismutase elevates reactive species: comparison of nitration and oxidation of proteins in different brain regions of transgenic mice with amyotrophic lateral sclerosis. Neuroscience 146:255-264

79. Miana-Mena FJ, González-Mingot C, Larrodé P, Muñoz MJ, Oliván S, Fuentes-Broto L, Martínez-Ballarín E, Reiter RJ, Osta R, García JJ (2011) Monitoring systemic oxidative stress in an animal model of amyotrophic lateral sclerosis. J Neurol 258: $762-769$ 
80. Morimoto N, Miyazaki K, Kurata T, Ikeda Y, Matsuura T, Kang D, Ide T, Abe K (2012) Effect of mitochondrial transcription factor a overexpression on motor neurons in amyotrophic lateral sclerosis model mice. J Neurosci Res 90:1200-1208

81. Seo J, Baek I, Leem Y, Kim T, Cho Y, Lee SM, Park YH, Han P (2011) SK-PC-B70M alleviates neurologic symptoms in G93ASOD1 amyotrophic lateral sclerosis mice. Brain Res 1368:299307

82. Casoni F, Basso M, Massignan T, Gianazzail E, Cheroni C, Salmona M, Bendotti C, Bonetto V (2005) Protein nitration in a mouse model of familial amyotrophic lateral sclerosis: possible multifunctional role in the pathogenesis. J Biol Chem 280: 16295-16304

83. Nardo G, Pozzi S, Mantovani S, Garbelli S, Marinou K, Basso M, Mora G, Bendotti C, Bonetto V (2009) Nitroproteomics of peripheral blood mononuclear cells from patients and a rat model of ALS. Antioxid Redox Signal 11:1559-1567

84. Basso M, Samengo G, Nardo G, Massignan T, D’Alessandro G, Tartari S, Cantoni L, Marino M, Cheroni C, de Biasi S, Giordana MT, Strong MJ, Estevez AG, Salmona M, Bendotti C, Bonetto V (2009) Characterization of detergent-insoluble proteins in ALS indicates a causal link between nitrative stress and aggregation in pathogenesis. PLoS ONE 4

85. Cha CI, Chung YH, Shin C, Shin DH, Kim YS, Gurney ME, Lee KW (2000) Immunocytochemical study on the distribution of nitrotyrosine in the brain of the transgenic mice expressing a human $\mathrm{Cu} / \mathrm{Zn}$ SOD mutation. Brain Res 853:156-161

86. Tokuda E, Ono S, Ishige K, Watanabe S, Okawa E, Ito Y, Suzuki T (2008) Ammonium tetrathiomolybdate delays onset, prolongs survival, and slows progression of disease in a mouse model for amyotrophic lateral sclerosis. Exp Neurol 213:122-128

87. Chi L, Ke Y, Luo C, Gozal D, Liu R (2007) Depletion of reduced glutathione enhances motor neuron degeneration in vitro and in vivo. Neuroscience 144:991-1003

88. Vargas MR, Johnson DA, Johnson JA (2011) Decreased glutathione accelerates neurological deficit and mitochondrial pathology in familial ALS-linked hSOD1G93A mice model. Neurobiol Dis 43:543-551

89. Vargas MR, Johnson DA, Sirkis DW, Messing A, Johnson JA (2008) Nrf2 activation in astrocytes protects against neurodegeneration in mouse models of familial amyotrophic lateral sclerosis. J Neurosci 28:13574-13581

90. Kato S, Kato M, Abe Y, Matsumura T, Nishino T, Aoki M, Itoyama Y, Asayama K, Awaya A, Hirano A, Ohama E (2005) Redox system expression in the motor neurons in amyotrophic lateral sclerosis (ALS): immunohistochemical studies on sporadic ALS, superoxide dismutase 1 (SOD1)-mutated familial ALS, and SOD1-mutated ALS animal models. Acta Neuropathol 110:101112

91. Kato S, Saeki Y, Aoki M, Nagai M, Ishigaki A, Itoyama Y, Kato M, Asayama K, Awaya A, Hirano A, Ohama E (2004) Histological evidence of redox system breakdown caused by superoxide dismutase 1 (SOD1) aggregation is common to SOD1mutated neurons in humans and animal models. Acta Neuropathol 107:149-158

92. Cudkowicz ME, Pastusza KA, Sapp PC, Mathews RK, Leahy J, Pasinelli P, Francis JW, Jiang D, Andersen JK, Brown RH Jr (2002) Survival in transgenic ALS mice does not vary with CNS glutathione peroxidase activity. Neurology 59:729-734

93. Lucchetti J, Marino M, Papa S, Tortarolo M, Guiso G, Pozzi S, Bonetto V, Caccia S, Beghi E, Bendotti C, Gobbi M (2013) A mouse model of familial ALS has increased CNS levels of endogenous Ubiquino19/10 and does not benefit from exogenous administration of Ubiquinol10. PLoS ONE 8

94. Klivenyi P, Kiaei M, Gardian G, Calingasan NY, Beal MF (2004) Additive neuroprotective effects of creatine and cyclooxygenase 2 inhibitors in a transgenic mouse model of amyotrophic lateral sclerosis. J Neurochem 88:576-582

95. Peña-Altamira E, Crochemore C, Virgili M, Contestabile A (2005) Neurochemical correlates of differential neuroprotection by longterm dietary creatine supplementation. Brain Res 1058:183-188

96. Zhang W, Narayanan M, Friedlander RM (2003) Additive neuroprotective effects of minocycline with creatine in a mouse model of ALS. Ann Neurol 53:267-270

97. Matthews RT, Ferrante RJ, Klivenyi P, Yang L, Klein AM, Mueller G, Kaddurah-Daouk R, Beal MF (1999) Creatine and cyclocreatine attenuate MPTP neurotoxicity. Exp Neurol 157: 142-149

98. Klivenyi P, Ferrante RJ, Matthews RT, Bogdanov MB, Klein AM, Andreassen OA, Mueller G, Wermer M, Kaddurah-Daouk R, Beal MF (1999) Neuroprotective effects of creatine in a transgenic animal model of amyotrophic lateral sclerosis. Nat Med 5:347-350

99. Choi J, Küstermann E, Dedeoglu A, Jenkins BG (2009) Magnetic resonance spectroscopy of regional brain metabolite markers in FALS mice and the effects of dietary creatine supplementation. Eur J Neurosci 30:2143-2150

100. Derave W, Van Den Bosch L, Lemmens G, Eijnde BO, Robberecht W, Hespel P (2003) Skeletal muscle properties in a transgenic mouse model for amyotrophic lateral sclerosis: effects of creatine treatment. Neurobiol Dis 13:264-272

101. Levkovitch-Verbin H, Waserzoog Y, Vander S, Makarovsky D, Piven I (2014) Minocycline upregulates pro-survival genes and downregulates pro-apoptotic genes in experimental glaucoma. Graefes Arch Clin Exp Ophthalmol 252:761-772

102. Jung C, Rong Y, Doctrow S, Baudry M, Malfroy B, Xu Z (2001) Synthetic superoxide dismutase/catalase mimetics reduce oxidative stress and prolong survival in a mouse amyotrophic lateral sclerosis model. Neurosci Lett 304:157-160

103. Chang Y, Kong Q, Shan X, Tian G, Ilieva H, Cleveland DW, Rothstein JD, Borchelt DR, Wong PC, Lin C-G (2008) Messenger RNA oxidation occurs early in disease pathogenesis and promotes motor neuron degeneration in ALS. PLoS ONE 3

104. Zhang Y, Cook A, Kim J, Baranov SV, Jiang J, Smith K, Cormier K, Bennett E, Browser RP, Day AL, Carlisle DL, Ferrante RJ, Wang X, Friedlander RM (2013) Melatonin inhibits the caspase1/cytochrome c/caspase-3 cell death pathway, inhibits MT1 receptor loss and delays disease progression in a mouse model of amyotrophic lateral sclerosis. Neurobiol Dis 55:26-35

105. Tokuda E, Okawa E, Watanabe S, Ono S, Marklund SL (2013) Dysregulation of intracellular copper homeostasis is common to transgenic mice expressing human mutant superoxide dismutase1s regardless of their copper-binding abilities. Neurobiol Dis 54: 308-319

106. Song L, Chen L, Zhang X, Li J, Le W (2014) Resveratrol ameliorates motor neuron degeneration and improves survival in SOD1G93A mouse model of amyotrophic lateral sclerosis. BioMed Rese Int 2014

107. Dardiotis E, Panayiotou E, Feldman ML, Hadjisavvas A, Malas S, Vonta I, Hadjigeorgiou G, Kyriakou K, Kyriakides T (2013) Intraperitoneal melatonin is not neuroprotective in the G93ASOD1 transgenic mouse model of familial ALS and may exacerbate neurodegeneration. Neurosci Lett 548:170-175

108. Crow JP, Calingasan NY, Chen J, Hill JL, Beal MF (2005) Manganese porphyrin given at symptom onset markedly extends survival of ALS mice. Ann Neurol 58:258-265

109. Gurney ME, Cutting FB, Zhai P, Doble A, Taylor CP, Andrus PK, Hall ED (1996) Benefit of vitamin E, riluzole, and gabapentin in a transgenic model of familial amyotrophic lateral sclerosis. Ann Neurol 39:147-157

110. Snow RJ, Turnbull J, Da Silva S, Jiang F, Tarnopolsky MA (2003) Creatine supplementation and riluzole treatment provide similar 
beneficial effects in copper, zinc superoxide dismutase (G93A) transgenic mice. Neuroscience 119:661-667

111. Koh J, Kim D, Hwang JY, Kim YH, Seo JH (1999) Antioxidative and proapoptotic effects of riluzole on cultured cortical neurons. $\mathrm{J}$ Neurochem 72:716-723

112. http://www.icd10data.com/ICD10CM/Codes/G00-G99/G20G26/G20-/G20. Accessed 15 May 2015

113. Gandhi SAA (2012) Mechanism of oxidative stress in neurodegeneration. Oxid Med Cell Longev 2012:428010

114. Dexter DT, Carter CJ, Wells FR, Javoy-Agid F, Agid Y, Lees A, Jenner P, Marsden CD (1989) Basal lipid peroxidation in substantia nigra is increased in Parkinson's disease. J Neurochem 52:381-389

115. Mythri RB, Venkateshappa C, Harish G, Mahadevan A, Muthane UB, Yasha TC, Srinivas Bharath MM, Shankar SK (2011) Evaluation of markers of oxidative stress, antioxidant function and astrocytic proliferation in the striatum and frontal cortex of Parkinson's disease brains. Neurochem Res 36:1452-1463

116. Castellani RJ, Perry G, Siedlak SL, Nunomura A, Shimohama S, Zhang J, Montine T, Sayre LM, Smith MA (2002) Hydroxynonenal adducts indicate a role for lipid peroxidation in neocortical and brainstem Lewy bodies in humans. Neurosci Lett 319:25-28

117. Shamoto-Nagai M, Maruyama W, Hashizume Y, Yoshida M, Osawa T, Riederer P, Naoi M (2007) In parkinsonian substantia nigra, a-synuclein is modified by acrolein, a lipid-peroxidation product, and accumulates in the dopamine neurons with inhibition of proteasome activity. J Neural Transm 114:1559-1567

118. Yoritaka A, Hattori N, Uchida K, Tanaka M, Stadtman ER, Mizuno Y (1996) Immunohistochemical detection of 4hydroxynonenal protein adducts in Parkinson disease. Proc Natl Acad Sci U S A 93:2696-2701

119. Xiang W, Schlachetzki JCM, Helling S, Bussmann JC, Berlinghof M, Schäffer TE, Marcus K, Winkler J, Klucken J, Becker C (2013) Oxidative stress-induced posttranslational modifications of alphasynuclein: specific modification of alpha-synuclein by 4-hydroxy2-nonenal increases dopaminergic toxicity. Mol Cell Neurosci 54: 71-83

120. Fessel JP, Hulette C, Powell S, Roberts LJ II, Zhang J (2003) Isofurans, but not F2-isoprostanes, are increased in the substantia nigra of patients with Parkinson's disease and with dementia with Lewy body disease. J Neurochem 85:645-650

121. Alam ZI, Daniel SE, Lees AJ, Marsden DC, Jenner P, Halliwell B (1997) A generalised increase in protein carbonyls in the brain in Parkinson's but not incidental Lewy body disease. J Neurochem 69:1326-1329

122. Ogata M, Kaneya D, Shin-Ya K, Li L, Abe Y, Katoh H, Seki S, Seki Y, Gonda R, Urano S, Endo T (2005) Trapping effect of eugenol on hydroxyl radicals induced by L-DOPA in vitro. Chem Pharm Bull 53:1167-1170

123. Good PF, Hsu A, Werner P, Perl DP, Warren Olanow C (1998) Protein nitration in Parkinson's disease. J Neuropathol Exp Neurol 57:338-342

124. Zhang J, Perry G, Smith MA, Robertson D, Olson SJ, Graham DG, Montine TJ (1999) Parkinson's disease is associated with oxidative damage to cytoplasmic DNA and RNA in substantia nigra neurons. Am J Pathol 154:1423-1429

125. Alam ZI, Jenner A, Daniel SE, Lees AJ, Cairns N, Marsden CD, Jenner P, Halliwell B (1997) Oxidative DNA damage in the Parkinsonian brain: an apparent selective increase in 8 hydroxyguanine levels in substantia nigra. J Neurochem 69: 1196-1203

126. Kikuchi A, Takeda A, Onodera H, Kimpara T, Hisanaga K, Sato N, Nunomura A, Castellani RJ, Perry G, Smith MA, Itoyama Y (2002) Systemic increase of oxidative nucleic acid damage in
Parkinson's disease and multiple system atrophy. Neurobiol Dis 9:244-248

127. Isobe C, Abe T, Terayama Y (2010) Levels of reduced and oxidized coenzymeQ-10 and 8-hydroxy-2'-deoxyguanosine in the cerebrospinal fluid of patients with living Parkinson's disease demonstrate that mitochondrial oxidative damage and/or oxidative DNA damage contributes to the neurodegenerative process. Neurosci Lett 469:159-163

128. Boll M, Alcaraz-Zubeldia M, Montes S, Rios C (2008) Free copper, ferroxidase and SOD1 activities, lipid peroxidation and NOx content in the CSF. A different marker profile in four neurodegenerative diseases. Neurochem Res 33:1717-1723

129. Selley ML (1998) (E)-4-Hydroxy-2-nonenal may be involved in the pathogenesis of Parkinson's disease. Free Radic Biol Med 25: 169-174

130. Ilic TV, Jovanovic M, Jovicic A, Tomovic M (1999) Oxidative stress indicators are elevated in de novo Parkinson's disease patients. Funct Neurol 14:141-147

131. Shukla R, Rajani M, Srivastava N, Barthwal MK, Dikshit M (2006) Nitrite and malondialdehyde content in cerebrospinal fluid of patients with Parkinson's disease. Int J Neurosci 116:13911402

132. Sanders LH, Timothy Greenamyre J (2013) Oxidative damage to macromolecules in human Parkinson disease and the rotenone model. Free Radic Biol Med 62:111-120

133. Sato S, Mizuno Y, Hattori N (2005) Urinary 8hydroxydeoxyguanosine levels as a biomarker for progression of Parkinson disease. Neurology 64:1081-1083

134. Seet RCS, Lee CJ, Lim ECH, Tan JJH, Quek AML, Chong W, Looi W, Huang S, Wang H, Chan Y, Halliwell B (2010) Oxidative damage in Parkinson disease: measurement using accurate biomarkers. Free Radic Biol Med 48:560-566

135. Lee C-J, Seet RCS, Huang SH, Long LH, Halliwell B (2009) Different patterns of oxidized lipid products in plasma and urine of dengue fever, stroke, and Parkinson's disease patients: cautions in the use of biomarkers of oxidative stress. Antioxid Redox Signal 11:407-420

136. Ahlskog JE, Uitti RJ, Low PA, Tyce GM, Nickander KK, Petersen RC, Kokmen E (1995) No evidence for systemic oxidant stress in Parkinson's or Alzheimer's disease. Mov Disord 10:566-573

137. Molina J, Jiménez-Jiménez FJ, Fernandez-Calle P, Lalinde L, Tenias J, Pondal M, Vazquez A, Codoceo R (1992) Serum lipid peroxides in patients with Parkinson's disease. Neurosci Lett 136: $137-140$

138. Connolly J, Siderowf A, Clark CM, Mu D, Pratico D (2008) F2 isoprostane levels in plasma and urine do not support increased lipid peroxidation in cognitively impaired parkinson disease patients. Cogn Behav Neurol 21:83-86

139. Sian J, Dexter DT, Lees AJ, Daniel S, Agid Y, Javoy-Agid F, Jenner P, Marsden CD (1994) Alterations in glutathione levels in Parkinson's disease and other neurodegenerative disorders affecting basal ganglia. Ann Neurol 36:348-355

140. Perry TL, Yong VW (1986) Idiopathic Parkinson's disease, progressive supranuclear palsy and glutathione metabolism in the substantia nigra of patients. Neurosci Lett 67:269-274

141. Perry TL, Godin DV, Hansen S (1982) Parkinson's disease: a disorder due to nigral glutathione deficiency? Neurosci Lett 33: 305-310

142. Danielson SR, Andersen JK (2008) Oxidative and nitrative protein modifications in Parkinson's disease. Free Radic Biol Med 44: 1787-1794

143. Riederer P, Sofic E, Rausch W, Schmidt B, Reynolds GP, Jellinger K, Youdim MBH (1989) Transition metals, ferritin, glutathione, and ascorbic acid in parkinsonian brains. J Neurochem 52:515520 
144. Chinta SJ, Andersen JK (2008) Redox imbalance in Parkinson's disease. Biochim Biophys Acta Gen Subj 1780:1362-1367

145. Marttila RJ, Lorentz H, Rinne UK (1988) Oxygen toxicity protecting enzymes in Parkinson's disease: increase of superoxide dismutase-like activity in the substantia nigra and basal nucleus. J Neurol Sci 86:321-331

146. Kish SJ, Morito C, Hornykiewicz O (1985) Glutathione peroxidase activity in Parkinson's disease brain. Neurosci Lett 58:343346

147. Mbangata MB, Kartha RV, Mishra U, Coles LD, Tuite PJ, Cloyd JC (2014) Oxidative stress status in patients with Parkinson's disease on and off medication. Mov Disord 29:S143

148. Sechi G, Deledda MG, Bua G, Satta WM, Deiana GA, Pes GM, Rosati G (1996) Reduced intravenous glutathione in the treatment of early Parkinson's disease. Prog Neuro-Psychopharmacol Biol Psychiatry 20:1159-1170

149. Holmay MJ, Terpstra M, Coles LD, Mishra U, Ahlskog M, Öz G, Cloyd JC, Tuite PJ (2013) N-acetylcysteine boosts brain and blood glutathione in gaucher and Parkinson diseases. Clin Neuropharmacol 36:103-106

150. Katz M, Swanson RA, Glass GA (2014) Cerebrospinal fluid concentrations of N-acetylcysteine after oral administration: phase I trial in Parkinson's disease. Mov Disord 29:S247

151. Gorell JM, Ordidge RJ, Brown GG, Deniau J, Buderer NM, Helpern JA (1995) Increased iron-related MRI contrast in the substantia nigra in Parkinson's disease. Neurology 45:1138-1143

152. Devos D, Moreau C, Devedjian JC, Kluza J, Petrault M, Laloux C, Jonneaux A, Ryckewaert G, Garçon G, Rouaix N, Duhamel A, Jissendi P, Dujardin K, Auger F, Ravasi L, Hopes L, Grolez G, Firdaus W, Sablonnière B, Strubi-Vuillaume I, Zahr N, Destée A, Corvol J, Pöltl D, Leist M, Rose C, Defebvre L, Marchetti P, Cabantchik ZI, Bordet R (2014) Targeting chelatable iron as a therapeutic modality in Parkinson's disease. Antioxid Redox Signal 21:195-210

153. Shoulson I (1998) DATATOP: a decade of neuroprotective inquiry. Ann Neurol 44:S160-S166

154. Shoulson I, Fahn S, Oakes D, Kieburtz K, Lang A, Langston JW, LeWitt P, Olanow CW, Penney JB, Tanner C, Rudolph A, Pelusio RM (1993) Effects of tocopherol and deprenyl on the progression of disability in early Parkinson's disease. N Engl J Med 328:176183

155. Beal MF (2014) A randomized clinical trial of high-dosage coenzyme q10 in early parkinson disease no evidence of benefit. JAMA Neurol 71:543-552

156. Su W, Chen H, Zhang Z, Chen B, Wang L, Sun X, Shen Y, Li Y, Geng T, Zhao W, Zhang X (2004) A multi-center, randomized, vitamin $\mathrm{E}$ controlled and opening clinical trial of selegiline in patients with Parkinson's disease. Chin J Neurol 37:413-416

157. Shults CW, Oakes D, Kieburtz K, Flint Beal M, Haas R, Plumb S, Juncos JL, Nutt J, Shoulson I, Carter J, Kompoliti K, Perlmutter JS, Reich S, Stern M, Watts RL, Kurlan R, Molho E, Harrison M, Lew M (2002) Effects of coenzyme Q 10 in early Parkinson disease: evidence of slowing of the functional decline. Arch Neurol 59:1541-1550

158. Storch A, Jost WH, Vieregge P, Spiegel J, Greulich W, Durner J, MüLler T, Kupsch A, Henningsen H, Oertel WH, Fuchs G, Kuhn W, Niklowitz P, Koch R, Herting B, Reichmann H (2007) Randomized, double-blind, placebo-controlled trial on symptomatic effects of coenzyme Q10 in Parkinson disease. Arch Neurol 64:938-944

159. NINDS (2006) A randomized, double-blind, futility clinical trial of creatine and minocycline in early Parkinson disease. Neurology 66:664-671

160. Kieburtz K, Tilley B, Ravina B, Galpern W, Shannon K, Tanner C, Wooten GF (2008) A pilot clinical trial of creatine and minocycline in early Parkinson disease: 18 -month results. Clin Neuropharmacol 31:141-150

161. Bender A, Koch W, Elstner M, Schombacher Y, Bender J, Moeschl M, Gekeler F, Muller-Myhsok B, Gasser T, Tatsch K, Klopstock T (2006) Creatine supplementation in Parkinson disease: a placebo-controlled randomized pilot trial. Neurology 67: $1262-1264$

162. http://parkinsontrial.ninds.nih.gov/netpd-LS1-study-termination. htm. Accessed 15 May 2015

163. Hirayama M, Goto S, Nakamura T, Mizutani Y, Suzuki J, Watanabe H, Sobue G (2014) Oxdative stress maker (urinary 8hydroxy-2'-deoxyguanosine) was modified by treatment of various Parkinson's drug. Mov Disord 29:S140

164. Sen CK (1999) Glutathione homeostasis in response to exercise training and nutritional supplements. Mol Cell Biochem 196:3142

165. Elokda A, Di Francisco-Donoghue J, Lamberg EM, Werner WG (2010) Effects of exercise induced oxidative stress on glutathione levels in Parkinson's disease on and off medication. J Neurol 257: 1648-1653

166. Nikolova GD, Grigorov BG, Zheleva AM, Gadjeva VG (2014) Influence of therapy on some important final products of oxidation of lipids, proteins and nucleic acids in patients with Parkinson's diseases. Adv Biol Chem 4:253-260

167. Blesa J, Phani S, Jackson-Lewis V, Przedborski S (2012) Classic and new animal models of Parkinson's disease. J Biomed Biotechnol 2012

168. Ungerstedt U (1971) Postsynaptic supersensitivity after 6hydroxy-dopamine induced degeneration of the nigro-striatal dopamine system. Acta Physiol Scandinav, Suppl 367:69-93

169. Langston JW, Forno LS, Rebert CS, Irwin I (1984) Selective nigral toxicity after systemic administration of 1-methyl-4-phenyl-1,2,5, 6-tetrahydropyrine (MPTP) in the squirrel monkey. Brain Res 292: 390-394

170. Blesa J, Juri C, Collantes M, Peñuelas I, Prieto E, Iglesias E, Martí-Climent J, Arbizu J, Zubieta JL, Rodríguez-Oroz MC, García-García D, Richter JA, Cavada C, Obeso JA (2010) Progression of dopaminergic depletion in a model of MPTPinduced parkinsonism in non-human primates. An 18F-DOPA and 11C-DTBZ PET study. Neurobiol Dis 38:456-463

171. Ohashi S1, Mori A, Kurihara N, Mitsumoto Y, Nakai M (2006) Age-related severity of dopaminergic neurodegeneration to MPTP neurotoxicity causes motor dysfunction in C57BL/6 mice. Neurosci Lett 401(1-2):183-187 (2006 Jun 19;401(1-2):183-7. Epub 2006 Apr 3.)

172. Shimohama S, Hisahara S (2011) Toxin-induced and genetic animal models of Parkinson's disease. Parkinson's Dis

173. Betarbet R, Sherer TB, MacKenzie G, Garcia-Osuna M, Panov AV, Greenamyre JT (2000) Chronic systemic pesticide exposure reproduces features of Parkinson's disease. Nat Neurosci 3:13011306

174. McCormack AL, Atienza JG, Johnston LC, Andersen JK, Vu S, Di Monte DA (2005) Role of oxidative stress in paraquat-induced dopaminergic cell degeneration. J Neurochem 93:1030-1037

175. Kumar A, Leinisch F, Kadiiska MB, Corbett J, Mason RP (2015) Formation and implications of alpha-synuclein radical in maneband paraquat-induced models of Parkinson's disease. Mol Neurobiol

176. Smith MP, Cass WA (2007) Oxidative stress and dopamine depletion in an intrastriatal 6-hydroxydopamine model of Parkinson's disease. Neuroscience 144:1057-1066

177. Haleagrahara N, Siew CJ, Ponnusamy K (2013) Effect of quercetin and desferrioxamine on 6-hydroxydopamine (6-OHDA) induced neurotoxicity in striatum of rats. J Toxicol Sci 38:25-33

178. Dagdelen M, Akkaya H, Genc E (2013) The role of valproic acid and levodopa on oxidative stress in a 6-hydroxydopamine 
lesioned rat model of Parkinson's disease. Eur Neuropsychopharmacol 23:S197

179. Inden M, Kitamura Y, Kondo J, Hayashi K, Yanagida T, Takata K, Tsuchiya D, Yanagisawa D, Nishimura K, Taniguchi T, Shimohama S, Sugimoto H, Akaike A (2005) Serofendic acid prevents 6-hydroxydopamine-induced nigral neurodegeneration and drug-induced rotational asymmetry in hemi-parkinsonian rats. J Neurochem 95:950-961

180. Su-Fen Y, Zheng-Qin Y, Qin W, An-Sheng S, Xie-Nan H, JingShan S (2001) Protective effect and mechanism of Ginkgo biloba leaf extracts for Parkinson disease induced by 1-methyl-4-phenyl1,2,3,6-tetrahydropyridine. Acta Pharmacol Sin 22:1089-1093

181. Ghosh A, Kanthasamy A, Joseph J, Anantharam V, Srivastava P, Dranka BP, Kalyanaraman B, Kanthasamy AG (2012) Antiinflammatory and neuroprotective effects of an orally active apocynin derivative in pre-clinical models of Parkinson's disease. J Neuroinflammat 9

182. Bisht R, Kaur B, Gupta H, Prakash A (2014) Ceftriaxone mediated rescue of nigral oxidative damage and motor deficits in MPTP model of Parkinson's disease in rats. Neurotoxicology 44:71-79

183. Barbiero JK, Santiago R, Tonin FS, Boschen S, da Silva LM, de Paula Werner MF, da Cunha C, Lima MMS, Vital MABF (2014) PPAR- $\alpha$ agonist fenofibrate protects against the damaging effects of MPTP in a rat model of Parkinson's disease. Prog NeuroPsychopharmacol Biol Psychiatry 53:35-44

184. Verma R, Nehru B (2009) Effect of centrophenoxine against rotenone-induced oxidative stress in an animal model of Parkinson's disease. Neurochem Int 55:369-375

185. Zaitone SA, Abo-Elmatty DM, Shaalan AA (2012) Acetyl-1carnitine and (alpha)-lipoic acid affect rotenone-induced damage in nigral dopaminergic neurons of rat brain, implication for Parkinson's disease therapy. Pharmacol Biochem Behav 100: 347-360

186. Gokul K, Muralidhara (2014) Oral supplements of aqueous extract of tomato seeds alleviate motor abnormality, oxidative impairments and neurotoxicity induced by rotenone in mice: relevance to Parkinson's disease. Neurochem Res 39:1382-1394

187. Liang L, Huang J, Fulton R, Day BJ, Patel M (2007) An orally active catalytic metalloporphyrin protects against 1-methyl-4-phenyl-1,2,3,6-tetrahydropyridine neurotoxicity in vivo. J Neurosci 27:4326-4333

188. Chen L, Gao Y, Li X, Shen D, Sun F (2005) Melatonin protects against MPTP/MPP+-induced mitochondrial DNA oxidative damage in vivo and in vitro. J Pineal Res 39:34-42

189. Fujita K, Seike T, Yutsudo N, Ohno M, Yamada H, Yamaguchi H, Sakumi K, Yamakawa Y, Kido MA, Takaki A, Katafuchi T, Tanaka Y, Nakabeppu Y, Noda M (2009) Hydrogen in drinking water reduces dopaminergic neuronal loss in the 1-methyl-4-phenyl-1,2,3,6-tetrahydropyridine mouse model of Parkinson's disease. PLoS ONE 4

190. Singhal NK, Srivastava G, Patel DK, Jain SK, Singh MP (2011) Melatonin or silymarin reduces maneb- and paraquat-induced Parkinson's disease phenotype in the mouse. J Pineal Res 50:97109

191. Ahmad M, Saleem S, Ahmad AS, Yousuf S, Ansari MA, Khan MB, Ishrat T, Chaturvedi RK, Agrawal AK, Islam F (2005) Ginkgo biloba affords dose-dependent protection against 6hydroxydopamine-induced parkinsonism in rats: neurobehavioural, neurochemical and immunohistochemical evidences. J Neurochem 93:94-104

192. Thomas B, Mohanakumar KP (2004) Melatonin protects against oxidative stress caused by 1-methyl-4-phenyl-1, 2,3,6tetrahydropyridine in the mouse nigrostriatum. J Pineal Res 36 : 25-32

193. Zaminelli T, Gradowski RW, Bassani TB, Barbiero JK, Santiago RM, Maria-Ferreira D, Baggio CH, Vital MABF (2014)
Antidepressant and antioxidative effect of ibuprofen in the rotenone model of Parkinson's disease. Neurotoxicity Res

194. Karuppagounder SS, Madathil SK, Pandey M, Haobam R, Rajamma U, Mohanakumar KP (2013) Quercetin up-regulates mitochondrial complex-I activity to protect against programmed cell death in rotenone model of Parkinson's disease in rats. Neuroscience 236:136-148

195. Kaur H, Chauhan S, Sandhir R (2011) Protective effect of lycopene on oxidative stress and cognitive decline in rotenone induced model of Parkinson's disease. Neurochem Res 36: $1435-1443$

196. Khurana N, Gajbhiye A (2013) Ameliorative effect of Sida cordifolia in rotenone induced oxidative stress model of Parkinson's disease. Neurotoxicology 39:57-64

197. Chen C, Yin M, Hsu C, Liu T (2007) Antioxidative and antiinflammatory effects of four cysteine-containing agents in striatum of MPTP-treated mice. Nutrition 23:589-597

198. Kaya Y, Ozsoy O, Onullut E, Aslan M, Yildirim FB, Anullar A (2013) Beneficial effect of melatonin treatment on substantia nigra in an experimental model of Parkinson's disease. J Neurol Sci 30: 142

199. Sharma A, Kaur P, Kumar V, Gill KD (2007) Attenuation of 1methyl-4-phenyl-1,2,3,6-tetrahydropyridine induced nigrostriatal toxicity in mice by N-acetyl cysteine. Cell Mol Biol 53:48-55

200. Shin JY, Park H, Ahn YH, Lee PH (2009) Neuroprotective effect of 1-dopa on dopaminergic neurons is comparable to pramipexol in MPTP-treated animal model of Parkinson's disease: a direct comparison study. J Neurochem 111:1042-1050

201. Sutherland GT, Chami B, Youssef P, Witting PK (2013) Oxidative stress in Alzheimer's disease: primary villain or physiological byproduct? Redox Rep 18:134-141

202. Wolfson C, Wolfson DB, Asgharian M, M'Lan CE, Østbye T, Rockwood K, Hogan DB (2001) A reevaluation of the duration of survival after the onset of dementia. N Engl J Med 344:11111116

203. Martins RN, Harper CG, Stokes GB, Masters CL (1986) Increased cerebral glucose-6-phosphate dehydrogenase activity in Alzheimer's disease may reflect oxidative stress. J Neurochem 46:1042-1045

204. Sultana R, Butterfield DA (2010) Role of oxidative stress in the progression of Alzheimer's disease. J Alzheimer's Dis 19:341353

205. Ansari MA, Scheff SW (2010) Oxidative stress in the progression of Alzheimer disease in the frontal cortex. J Neuropathol Exp Neurol 69:155-167

206. Lüth H, Münch G, Arendt T (2002) Aberrant expression of NOS isoforms in Alzheimer's disease is structurally related to nitrotyrosine formation. Brain Res 953:135-143

207. Lüth H, Holzer M, Gärtner U, Staufenbiel M, Arendt T (2001) Expression of endothelial and inducible NOS-isoforms is increased in Alzheimer's disease, in APP23 transgenic mice and after experimental brain lesion in rat: evidence for an induction by amyloid pathology. Brain Res 913:57-67

208. Massaad CA (2011) Neuronal and vascular oxidative stress in Alzheimer's disease. Curr Neuropharmacol 9:662-673

209. Toda N, Ayajiki K, Okamura T (2009) Cerebral blood flow regulation by nitric oxide in neurological disorders. Can J Physiol Pharmacol 87:581-594

210. Lovell MA, Gabbita SP, Markesbery WR (1999) Increased DNA oxidation and decreased levels of repair products in Alzheimer's disease ventricular CSF. J Neurochem 72:771-776

211. Mecocci P, MacGarvey U, Beal MF (1994) Oxidative damage to mitochondrial DNA is increased in Alzheimer's disease. Ann Neurol 36:747-751 
212. Lovell MA, Xie C, Markesbery WR (1998) Decreased glutathione transferase activity in brain and ventricular fluid in Alzheimer's disease. Neurology 51:1562-1566

213. Casado Á, Encarnación López-Fernández M, Concepción Casado M, De La Torre R (2008) Lipid peroxidation and antioxidant enzyme activities in vascular and Alzheimer dementias. Neurochem Res 33:450-458

214. Marcus DL, Thomas C, Rodriguez C, Simberkoff K, Tsai JS, Strafaci JA, Freedman ML (1998) Increased peroxidation and reduced antioxidant enzyme activity in Alzheimer's disease. Exp Neurol 150:40-44

215. Spalletta G, Bernardini S, Bellincampi L, Federici G, Trequattrini A, Ciappi F, Bria P, Caltagirone C, Bossù P (2007) Glutathione Stransferase $\mathrm{p} 1$ and $\mathrm{t} 1$ gene polymorphisms predict longitudinal course and age at onset of Alzheimer disease. Am J Geriatr Psychiatr 15:879-887

216. Paz-Y-Miño C, Carrera C, López-Cortés A, Muñoz MJ, Cumbal N, Castro B, Cabrera A, Sánchez ME (2010) Genetic polymorphisms in apolipoprotein e and glutathione peroxidase 1 genes in the Ecuadorian population affected with Alzheimer's disease. Am J Med Sci 340:373-377

217. Aoyama K, Nakaki T (2013) Impaired glutathione synthesis in neurodegeneration. Int J Mol Sci 14:21021-21044

218. Sultana R, Piroddi M, Galli F, Butterfield DA (2008) Protein levels and activity of some antioxidant enzymes in hippocampus of subjects with amnestic mild cognitive impairment. Neurochem Res 33:2540-2546

219. Foy CJ, Passmore AP, Vahidassr MD, Young IS, Lawson JT (1999) Plasma chain-breaking antioxidants in Alzheimer's disease, vascular dementia and Parkinson's disease. QJM - Month J Assoc Phys 92:39-45

220. Kim T, Pae C, Yoon S, Jang W, Lee NJ, Kim J, Lee S, Lee C, Paik I, Lee C (2006) Decreased plasma antioxidants in patients with Alzheimer's disease. Int J Geriatr Psychiatr 21:344-348

221. Giavarotti L, Simon KA, Azzalis LA, Fonseca FLA, Lima AF, Freitas MCV, Brunialti MKC, Salomão R, Moscardi AAVS, M. Montaño MBM, Ramos LR, Junqueira VBC (2013) Mild systemic oxidative stress in the subclinical stage of Alzheimer's disease. Oxidat Med Cell Longevity

222. Arlt S, Müller-Thomsen T, Beisiegel U, Kontush A (2012) Effect of one-year vitamin C- and E-supplementation on cerebrospinal fluid oxidation parameters and clinical course in Alzheimer's disease. Neurochem Res 37:2706-2714

223. Galasko DR, Peskind E, Clark CM, Quinn JF, Ringman JM, Jicha GA, Cotman C, Cottrell B, Montine TJ, Thomas RG, Aisen P (2012) Antioxidants for Alzheimer disease: a randomized clinical trial with cerebrospinal fluid biomarker measures. Arch Neurol 69: 836-841

224. Dysken MW, Sano M, Asthana S, Vertrees JE, Pallaki M, Llorente M, Love S, Schellenberg GD, McCarten JR, Malphurs J, Prieto S, Chen P, Loreck DJ, Trapp G, Bakshi RS, Mintzer JE, Heidebrink JL, Vidal-Cardona A, Arroyo LM, Cruz AR, Zachariah S, Kowall NW, Chopra MP, Craft S, Thielke S, Turvey CL, Woodman C, Monnell KA, Gordon K, Tomaska J, Segal Y, Peduzzi PN, Guarino PD (2014) Effect of vitamin E and memantine on functional decline in Alzheimer disease: the TEAM-AD VA cooperative randomized trial. JAMA - J Am Med Assoc 311:33-44

225. Thal LJ, Grundman M, Berg J, Ernstrom K, Margolin R, Pfeiffer E, Weiner MF, Zamrini E, Thomas RG (2003) Idebenone treatment fails to slow cognitive decline in Alzheimer's disease. Neurology 61:1498-1502

226. Quinn JF, Raman R, Thomas RG, Yurko-Mauro K, Nelson EB, Van Dyck C, Galvin JE, Emond J, Jack CR Jr, Weiner M, Shinto L, Aisen PS (2010) Docosahexaenoic acid supplementation and cognitive decline in Alzheimer disease: a randomized trial. JAMA - J Am Med Assoc 304:1903-1911
227. Freund-Levi Y, Eriksdotter-Jönhagen M, Cederholm T, Basun H, Faxén-Irving G, Garlind A, Vedin I, Vessby B, Wahlund L, Palmblad J (2006) $\omega-3$ fatty acid treatment in 174 patients with mild to moderate Alzheimer disease: OmegAD study — a randomized double-blind trial. Arch Neurol 63:1402-1408

228. Shinto L, Quinn J, Montine T, Dodge HH, Woodward W, BaldaufWagner S, Waichunas D, Bumgarner L, Bourdette D, Silbert L, Kaye J (2014) A randomized placebo-controlled pilot trial of omega-3 fatty acids and alpha lipoic acid in Alzheimer's disease. J Alzheimer's Dis 38:111-120

229. Ringman JM, Frautschy SA, Teng E, Begum AN, Bardens J, Beigi M, Gylys KH, Badmaev V, Heath DD, Apostolova LG, Porter V, Vanek Z, Marshall GA, Hellemann G, Sugar C, Masterman DL, Montine TJ, Cummings JL, Cole GM (2012) Oral curcumin for Alzheimer's disease: tolerability and efficacy in a 24-week randomized, double blind, placebo-controlled study. Alzheimer's Res Therapy 4

230. Baum L, Lam CWK, Cheung SK, Kwok T, Lui V, Tsoh J, Lam L, Leung V, Hui E, Ng C, Woo J, Chiu HFK, Goggins WB, Zee BC, Cheng KF, Fong CYS, Wong A, Mok H, Chow MSS, Ho PC, Ip SP, Ho CS, Yu XW, Lai CYL, Chan M, Szeto S, Chan IHS, Mok V (2008) Six-month randomized, placebo-controlled, double-blind, pilot clinical trial of curcumin in patients with Alzheimer disease. J Clin Psychopharmacol 28:110-113

231. Disilvestro RA, Joseph E, Zhao S, Bomser J (2012) Diverse effects of a low dose supplement of lipidated curcumin in healthy middle aged people. Nutrition $\mathrm{J} 11$

232. Truelsen T, Thudium D, Grønbæk M (2002) Amount and type of alcohol and risk of dementia: the Copenhagen City Heart Study. Neurology 59:1313-1319

233. https://clinicaltrials.gov/ct2/show/NCT01504854. Accessed 15 May 2015

234. Klugman A, Naughton DP, Isaac M, Shah I, Petroczi A, Tabet N (2012) Antioxidant enzymatic activities in Alzheimer's disease: the relationship to acetylcholinesterase inhibitors. J Alzheimer's Dis 30:467-474

235. Gubandru M, Margina D, Tsitsimpikou C, Goutzourelas N, Tsarouhas K, Ilie M, Tsatsakis AM, Kouretas D (2013) Alzheimer's disease treated patients showed different patterns for oxidative stress and inflammation markers. Food Chem Toxicol 61:209-214

236. Snalina N, Alessenko A, Gavrilova S, Gurianova S, Prochorov A, Kononova E, Fedorova Y (2014) Memantine changes lipids spectrum and lipid peroxidation in animal brain and plasma of patients with Alzheimer's disease. FEBS J 281:86

237. Hu D, Li C, Han N, Miao L, Wang D, Liu Z, Wang H, Yin J (2012) Deoxyschizandrin isolated from the fruits of Schisandra chinensis ameliorates a $\beta$ induced memory impairment in mice. Planta Med 78:1332-1336

238. Hou X, Wu D, Zhang C, Yan R, Yang C, Rong C, Zhang L, Chang X, Su R, Zhang S, He W, Qu Z, Li S, Su Z, Chen Y, Wang Q, Fang S (2014) Bushen-Yizhi formula ameliorates cognition deficits and attenuates oxidative stress-related neuronal apoptosis in scopolamine-induced senescence in mice. Int J Mol Med 34: 429-439

239. Chonpathompikunlert P, Wattanathorn J, Muchimapura S (2010) Piperine, the main alkaloid of Thai black pepper, protects against neurodegeneration and cognitive impairment in animal model of cognitive deficit like condition of Alzheimer's disease. Food Chem Toxicol 48:798-802

240. Veerendra Kumar MH, Gupta YK (2003) Effect of Centella asiatica on cognition and oxidative stress in an intracerebroventricular streptozotocin model of Alzheimer's disease in rats. Clin Exp Pharmacol Physiol 30:336-342 
241. Li X, Zhao X, Xu X, Mao X, Liu Z, Li H, Guo L, Bi K, Jia Y (2014) Schisantherin A recovers A(beta)-induced neurodegeneration with cognitive decline in mice. Physiol Behav 132:10-16

242. Fan Y, Hu J, Li J, Yang Z, Xin X, Wang J, Ding J, Geng M (2005) Effect of acidic oligosaccharide sugar chain on scopolamineinduced memory impairment in rats and its related mechanisms. Neurosci Lett 374:222-226

243. Richards JG, Higgins GA, Ouagazzal A, Ozmen L, Kew JNC, Bohrmann B, Malherbe P, Brockhaus M, Loetscher H, Czech C, Huber G, Bluethmann H, Jacobsen H, Kemp JA (2003) PS2APP transgenic mice, coexpressing hPS2mut and hAPPswe, show age-related cognitive deficits associated with discrete brain amyloid deposition and inflammation. J Neurosci 23:8989-9003

244. Cavanaugh SE, Pippin JJ, Barnard ND (2014) Animal models of Alzheimer disease: historical pitfalls and a path forward. ALTEX 31:279-302

245. Götz J, Ittner LM (2008) Animal models of Alzheimer's disease and frontotemporal dementia. Nat Rev Neurosci 9:532-544

246. Lannert H, Hoyer S (1998) Intracerebroventricular administration of streptozotocin causes long-term diminutions in learning and memory abilities and in cerebral energy metabolism in adult rats. Behav Neurosci 112:1199-1208

247. Jhoo JH, Kim H, Nabeshima T, Yamada K, Shin E, Jhoo W, Kim W, Kang K, Jo SA, Woo JI (2004) $\beta$-Amyloid (1-42)-induced learning and memory deficits in mice: involvement of oxidative burdens in the hippocampus and cerebral cortex. Behav Brain Res 155:185-196

248. Budzynska B, Boguszewska-Czubara A, Kruk-Slomka M, Skalicka-Wozniak K, Michalak A, Musik I, Biala G (2015) Effects of imperatorin on scopolamine-induced cognitive impairment and oxidative stress in mice. Psychopharmacology (Berl) 232:931-942

249. Goverdhan P, Sravanthi A, Mamatha T (2012) Neuroprotective effects of meloxicam and selegiline in scopolamine-induced cognitive impairment and oxidative stress. Int J Alzheimer's Dis

250. Javed H, Khan MM, Khan A, Vaibhav K, Ahmad A, Khuwaja G, Ahmed ME, Raza SS, Ashafaq M, Tabassum R, Siddiqui MS, ElAgnaf OM, Safhi MM, Islam F (2011) S-allyl cysteine attenuates oxidative stress associated cognitive impairment and neurodegeneration in mouse model of streptozotocin-induced experimental dementia of Alzheimer's type. Brain Res 1389:133-142

251. Siedlak SL, Casadesus G, Webber KM, Pappolla MA, Atwood CS, Smith MA, Perry G (2009) Chronic antioxidant therapy reduces oxidative stress in a mouse model of Alzheimer's disease. Free Radic Res 43:156-164

252. Harrison FE, Hosseini AH, McDonald MP, May JM (2009) Vitamin $\mathrm{C}$ reduces spatial learning deficits in middle-aged and very old APP/PSEN1 transgenic and wild-type mice. Pharmacol Biochem Behav 93:443-450

253. Hartl D, Schuldt V, Forler S, Zabel C, Klose J, Rohe M (2012) Presymptomatic alterations in energy metabolism and oxidative stress in the APP23 mouse model of Alzheimer disease. J Proteome Res 11:3295-3304

254. Feng Z, Qin C, Chang Y, Zhang J (2006) Early melatonin supplementation alleviates oxidative stress in a transgenic mouse model of Alzheimer's disease. Free Radic Biol Med 40:101-109

255. Zhang W, Bai M, Xi Y, Hao J, Liu L, Mao N, Su C, Miao J, Li Z (2012) Early memory deficits precede plaque deposition in APPswe/PS1dE9 mice: involvement of oxidative stress and cholinergic dysfunction. Free Radic Biol Med 52:1443-1452

256. Khan MB, Khan MM, Khan A, Ahmed ME, Ishrat T, Tabassum R, Vaibhav K, Ahmad A, Islam F (2012) Naringenin ameliorates Alzheimer's disease (AD)-type neurodegeneration with cognitive impairment (AD-TNDCI) caused by the intracerebroventricularstreptozotocin in rat model. Neurochem Int 61:1081-1093
257. Harrison FE, May JM, McDonald MP (2010) Vitamin C deficiency increases basal exploratory activity but decreases scopolamineinduced activity in APP/PSEN1 transgenic mice. Pharmacol Biochem Behav 94:543-552

258. Duffy AM, Hölscher C (2013) The incretin analogue D-Ala2GIP reduces plaque load, astrogliosis and oxidative stress in an APP/ PS1 mouse model of Alzheimer's disease. Neuroscience 228:294300

259. Wang D, Liu L, Zhu X, Wu W, Wang Y (2014) Hesperidin alleviates cognitive impairment, mitochondrial dysfunction and oxidative stress in a mouse model of Alzheimer's disease. Cell Mol Neurobiol

260. Otalora BB, Popovic N, Gambini J, Popovic M, Viña J, BonetCosta V, Reiter RJ, Camello PJ, Rol MÁ, Madrid JA (2012) Circadian system functionality, hippocampal oxidative stress, and spatial memory in the APPswePS1dE9 transgenic model of Alzheimer disease: effects of melatonin or ramelteon. Chronobiol Int 29:822-834

261. Saxena G, Singh SP, Agrawal R, Nath C (2008) Effect of donepezil and tacrine on oxidative stress in intracerebral streptozotocin-induced model of dementia in mice. Eur J Pharmacol 581:283-289

262. Benzie IFF, Strain JJ (1996) The ferric reducing ability of plasma (FRAP) as a measure of 'antioxidant power': the FRAP assay. Anal Biochem 239:70-76

263. Kracmarova A, Bandouchova H, Pikula J, Pohanka M (2012) Tacrine is implicated in oxidative stress in the laboratory guinea pig model. Neuroendocrinol Lett 33:136-144

264. Khurana S, Jain S, Mediratta PK, Banerjee BD, Sharma KK (2012) Protective role of curcumin on colchicine-induced cognitive dysfunction and oxidative stress in rats. Hum Exp Toxicol 31: 686-697

265. Mahdy K, Shaker O, Wafay H, Nassar Y, Hassan H, Hussein A (2012) Effect of some medicinal plant extracts on the oxidative stress status in Alzheimer's disease induced in rats. Eur Rev Med Pharmacol Sci 16:31-42

266. Kumar A, Prakash A, Pahwa D (2011) Galantamine potentiates the protective effect of rofecoxib and caffeic acid against intrahippocampal kainic acid-induced cognitive dysfunction in rat. Brain Res Bull 85:158-168

267. Pietá Dias C, Martins de Lima MN, Presti-Torres J, Dornelles A, Garcia VA, Siciliani Scalco F, Rewsaat Guimarães M, Constantino L, Budni P, Dal-Pizzol F, Schröder N (2007) Memantine reduces oxidative damage and enhances long-term recognition memory in aged rats. Neuroscience 146:1719-1725

268. Arif M, Chikuma T, Ahmed MM, Nakazato M, Smith MA, Kato T (2009) Effects of memantine on soluble A $\beta 25$-35-induced changes in peptidergic and glial cells in Alzheimer's disease model rat brain regions. Neuroscience 164:1199-1209

269. Rai S, Kamat PK, Nath C, Shukla R (2014) Glial activation and post-synaptic neurotoxicity: the key events in streptozotocin (ICV) induced memory impairment in rats. Pharmacol Biochem Behav 117:104-117

270. Kamat PK, Tota S, Saxena G, Shukla R, Nath C (2010) Okadaic acid (ICV) induced memory impairment in rats: a suitable experimental model to test anti-dementia activity. Brain Res 1309:6674

271. Nasr P, Carbery T, Geddes JW (2009) N-Methyl-D-aspartate receptor antagonists have variable affect in 3-nitropropionic acid toxicity. Neurochem Res 34:490-498

272. Rojas JC, Saavedra JA, Gonzalez-Lima F (2008) Neuroprotective effects of memantine in a mouse model of retinal degeneration induced by rotenone. Brain Res 1215:208-217

273. Zaja-Milatovic S, Gupta RC, Aschner M, Milatovic D (2009) Protection of DFP-induced oxidative damage and 
neurodegeneration by antioxidants and NMDA receptor antagonist. Toxicol Appl Pharmacol 240:124-131

274. LÃ $1 / 4$ J, Lin PH, Yao Q, Chen C (2010) Chemical and molecular mechanisms of antioxidants: experimental approaches and model systems. J Cell Mol Med 14:840-860

275. Rahal A, Kumar A, Singh V, Yadav B, Tiwari R, Chakraborty S, Dhama K (2014) Oxidative stress, prooxidants, and antioxidants: the interplay. BioMed Res Int 2014

276. Townsend DM, Tew KD (2003) The role of glutathione-Stransferase in anti-cancer drug resistance. Oncogene 22:73697375

277. Tabart J, Kevers C, Pincemail J, Defraigne J, Dommes J (2009) Comparative antioxidant capacities of phenolic compounds measured by various tests. Food Chem 113:12261233
278. Siasos G, Tousoulis D, Tsigkou V, Kokkou E, Oikonomou E, Vavuranakis M, Basdra EK, Papavassiliou AG, Stefanadis C (2013) Flavonoids in atherosclerosis: an overview of their mechanisms of action. Curr Med Chem 20:2641-2660

279. Jomova K, Valko M (2011) Advances in metal-induced oxidative stress and human disease. Toxicology 283:65-87

280. Lushchak VI (2012) Glutathione homeostasis and functions: potential targets for medical interventions. J Amino Acids 2012

281. Djamali A (2007) Oxidative stress as a common pathway to chronic tubulointerstitial injury in kidney allografts. Am J Physiol Renal Physiol

282. Bartosz G (2009) Reactive oxygen species: destroyers or messengers? Biochem Pharmacol 77:1303-1315

283. Brieger K, Schiavone S, Miller FJ, Krause K- (2012) Reactive oxygen species: from health to disease. Swiss Medical Weekly 142 